\title{
Lost Opportunities in the Buildings Sector: Energy-Efficiency Analysis and Results
}
JA Dirks
DB Belzer
DM Anderson
KA Cort
DJ Hostick

September 2008

\section{Pacific Northwest}

NATIONAL LABORATORY 


\title{
DISCLAIMER
}

This report was prepared as an account of work sponsored by an agency of the United States Government. Neither the United States Government nor any agency thereof, nor Battelle Memorial Institute, nor any of their employees, makes any warranty, express or implied, or assumes any legal liability or responsibility for the accuracy, completeness, or usefulness of any information, apparatus, product, or process disclosed, or represents that its use would not infringe privately owned rights. Reference herein to any specific commercial product, process, or service by trade name, trademark, manufacturer, or otherwise does not necessarily constitute or imply its endorsement, recommendation, or favoring by the United States Government or any agency thereof, or Battelle Memorial Institute. The views and opinions of authors expressed herein do not necessarily state or reflect those of the United States Government or any agency thereof.

\author{
PACIFIC NORTHWEST NATIONAL LABORATORY \\ operated by \\ BATTELLE \\ for the \\ UNITED STATES DEPARTMENT OF ENERGY \\ under Contract DE-AC05-76RL01830
}

Printed in the United States of America

Available to DOE and DOE contractors from the

Office of Scientific and Technical Information,

P.O. Box 62, Oak Ridge, TN 37831-0062;

ph: (865) 576-8401

fax: (865) 576-5728

email: reports@adonis.osti.gov

\author{
Available to the public from the National Technical Information Service, \\ U.S. Department of Commerce, 5285 Port Royal Rd., Springfield, VA 22161 \\ ph: (800) 553-6847 \\ fax: $(703) 605-6900$ \\ email: orders@ntis.fedworld.gov \\ online ordering: http://www.ntis.gov/ordering.htm
}




\title{
Lost Opportunities in the Buildings Sector: Energy-Efficiency Analysis and Results
}

\author{
JA Dirks DB Belzer \\ DM Anderson KA Cort
}

DJ Hostick

September 2008

Prepared for

the U.S. Department of Energy

under Contract DE-AC05-76RL01830

Pacific Northwest National Laboratory

Richland, Washington 99352 



\section{Executive Summary}

While US federal investment in research and development of improved technologies in the buildings sector has been shown to result in significant energy efficiency gains for the nation, a substantial amount of additional energy- and carbon-saving benefits will not be realized at current investment levels. This report documents the analysis of achievable energy- and carbon-saving opportunities that would not be realized (or would be "lost") without requisite investment in technology research addressing the buildings sector - here defined as the sum of the commercial and residential sectors as characterized by the Energy Information Administration.

The approach compares commercial and residential primary energy consumption under the AEO 2008 Reference Case to consumption under the Department of Energy's Building Technologies Program "business as usual" case, and to a case designed to represent a much more aggressive pursuit of energyand carbon-saving technology advances, termed the "lost opportunities" case. Business as usual is represented by the planned fiscal year (FY) 2009 research portfolio of the Building Technologies Program being maintained over the 2009-2025 period. The lost opportunities case is represented by applying aggressive, but plausible, market penetration scenarios to the overnight technical potential of the technologies analyzed.

Of necessity in terms of resources and tractability, the approach is deterministic in nature. Uncertainty with respect to the modeling inputs or outputs has not been considered. As such, the report represents one possible outcome, determined based on conventional wisdom of expert buildings sector analysts. Therefore the estimates are not provided with confidence intervals - an acknowledged weakness among all such studies we have encountered. However, we offer the results and suggest that they are robust, but caution that a truly probabilistic analysis might suggest lower or higher estimated results.

The analysis shows that if supported at requisite levels, technologies developed through the Department of Energy (DOE)'s Building Technologies Program could result in annual energy savings of about 8.5 QBtu by 2025 - equivalent to the annual primary energy consumption of the state of California. The pathway to this level of savings also would result in the cumulative avoidance of an estimated $4.4 \mathrm{Gt}$ of carbon dioxide emissions over the 2009-2025 period. In percentage terms, for relative comparison, 8.5 QBtu equates to about $17.8 \%$ of the buildings sector projected energy consumption in 2025 , and $4.4 \mathrm{Gt}$ of carbon dioxide equates to about $10.4 \%$ of projected cumulative $\mathrm{CO} 2$ emissions in the buildings sector. These energy savings, if realized, would cause total primary energy consumption in the buildings sector to level off over the 2009-2025 study period to just below 2009 consumption levels, as opposed to the Reference Case projection suggesting continued steady growth in consumption.

The methodological approach developed for this analysis is fully integrated across end use services (e.g., lighting). Full accounting has been made for technologies that compete for the same end use load reduction. As such, the energy and carbon savings estimates do not include double counting of any savings from separate technologies. The approach does not rely on selecting one optimal pathway for technological research; it is instead based upon selecting reasonable end states for each performance parameter in each timeframe that could reasonably be expected to be achieved with significant additional investment above the "business-as-usual" case. As such, energy savings achieved do not represent the maximum possible primary energy savings under a greatly expanded buildings sector program and the 
end points do not necessarily represent the optimal research agenda. It is, however, the opinion of the authors that the end states and the potential savings are achievable and realistic with a substantial expansion of the buildings sector technology research agenda. Other pathways are possible and could result in similar energy savings estimates in the view of other experts. We compare our approach and results to other similar published studies, discussing significant methodological differences.

Energy flow maps developed for this analysis depict the flow of energy from source to end use in the buildings sector and reflect the sector's carbon footprint. For comparison, the energy flow of the lost opportunities case is superimposed over the AEO 2008 reference case to illustrate the potential reduction in the energy and carbon footprint of the buildings sector. 


\section{Acknowledgments}

The authors wish to acknowledge the helpful contributions of three people. Dr. Robert Margolis of the National Renewable Energy Laboratory was the original author of the energy analysis of DOE's Solar-Zero Energy Buildings Vision. His calculations estimate the potential impacts of a combined zeronet energy buildings vision involving both aggressive end-use efficiency and rooftop photovoltaic (PV) systems, and were adopted into this analysis. Edward Barbour of Navigant Consulting provided helpful review of the technological assumptions used to represent a very aggressive research approach for the Building Technologies Program. Nathan Johnson, a graphic artist at PNNL, developed the complex energy flow map graphics shown in this report. Dr. Leon Glicksman, PhD, of Massachusetts Institute of Technology and Dr. David Sailor, PhD, of Portland State University provided helpful review comments on an earlier draft of this report. 



\section{Acronyms and Abbreviations}

$\mathrm{ACH}$

AEO

AER

ASHRAE

BAU

BEAMS

BT

BTP

BTU

CBECS

CFL

CHPS

DOE

EERE

EIA

EISA

EPA

FEDS

FEMP

FY

GPRA

GW

HP

HVAC

IGU

KW

LED

LEED

LO

MF

MH

MMTCE

MYPP

NEMS

NREL

OMB
Air Changes per Hour

Annual Energy Outlook

Annual Energy Review

American Society of Heating Refrigeration and Air Conditioning Engineers

Business as Usual

Building Energy Analysis Modeling System

Building Technologies

Building Technologies Program

British Thermal Unit

Commercial Building Energy Consumption Survey

compact fluorescent lamp

Collaborative for High Performance Schools

Department of Energy

Office of Energy Efficiency and Renewable Energy

Energy Information Administration

Extended Industry Standard Architecture

Environmental Protection Agency

Facility Energy Decision System

Federal Energy Management Program

Fiscal Year

Government Performance and Results Act

Gigawatts

Horsepower

heating, ventilation and air conditioning

Insulating Glass Unit

Kilowatt

Light Emitting Diode

Leadership in Energy and Environmental Design

Lost Opportunities

Multifamily

Mobile Home/Manufactured Housing

Million Metric Tons of Carbon Emitted

Multi Year Program Plan

National Energy Modeling System

National Renewable Energy Laboratory

Office of Management and Budget 
PC

PNNL

PV

R\&D

RECS

SAI

SEIA

SF

SHGC

SSL

STEO

TVMI

VFD

VSD

VT
Personal Computer

Pacific Northwest National Laboratory

photovoltaic

Research and Development

Residential Energy Consumption Survey

Solar America Initiative

Solar Energy Industries Association

Single Family

Solar Heat Gain Coefficient

Solid State Lighting

Short Term Energy Outlook

Technology Validation and Market Introduction

Variable Frequency Drive

Variable Speed Drive

Visual Transmittance 


\section{Contents}

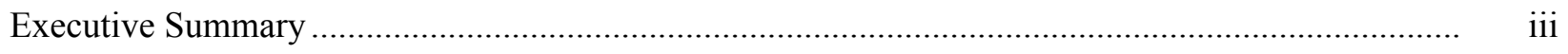

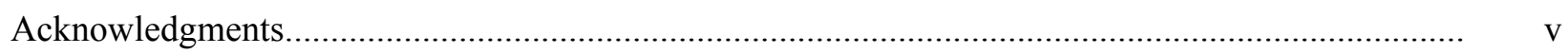

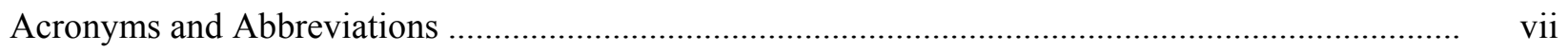

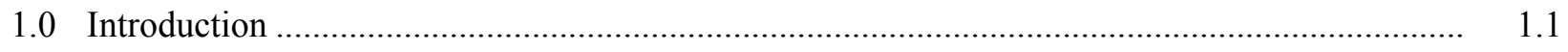

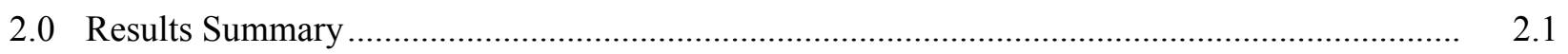

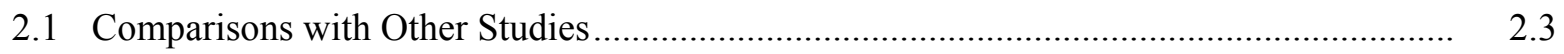

3.0 Commercial Sector Approach .................................................................................... 3.1

3.1 Commercial Penetration Rate Development …........................................................... 3.3

3.1.1 Existing Commercial Market ....................................................................... 3.4

3.1.2 New Commercial Market ............................................................................... 3.6

3.1.3 Market Penetration Summary ...................................................................... 3.7

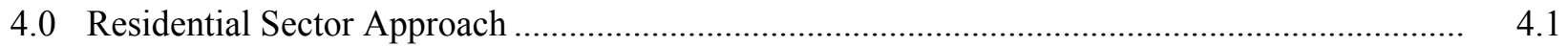

4.1 Residential Penetration Rate Development …............................................................. 4.2

4.1.1 New Residential Market................................................................................ 4.3

4.1.2 Existing Residential Market ......................................................................... 4.3

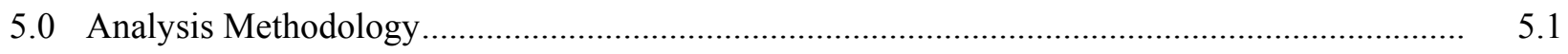

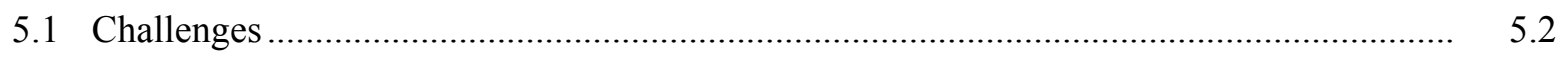

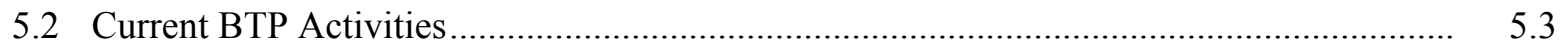

5.3 Lost Opportunities Technology Performance Assumptions............................................. 5.4

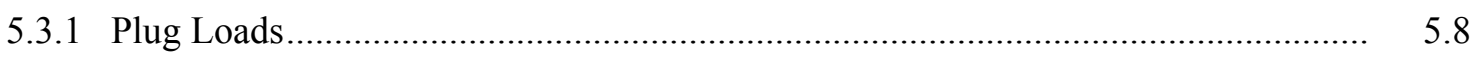

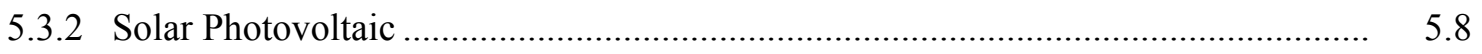

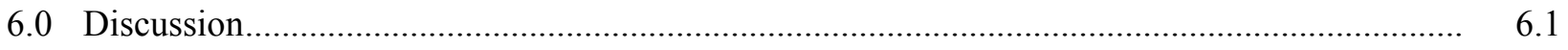

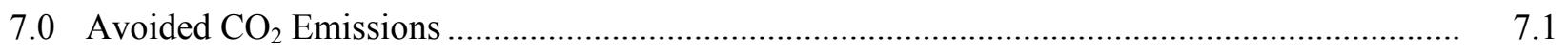

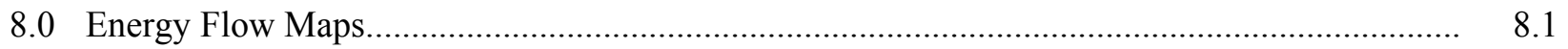

Appendix A - Projected Miscellaneous Electricity Consumption in the Commercial Sector ............. A. A

Appendix B - FY 2009 BTP Activity Level Benefits Analysis Results.......................................... B.1

Appendix C - Benefits of Solar-Zero Energy Buildings Vision...................................................... C.1

Appendix D - Benefits of the Vision ................................................................................... D.1 


\section{Figures}

2.1 Total Estimated Buildings-Sector Energy Consumption under Alternative Cases..................... 2.1

2.2 New and Existing Commercial Floorspace, 2008-2030, ....................................................... 2.2

2.3 New and Existing Housing Stock, 2008-2030, Analysis Methodology.................................... 2.3

3.1 AEO 2008 Reference Case Projection for the Commercial Sector, Broken Out by the End Uses Considered in This Analysis .................................................................................... 3.2

4.1 AEO 2008 Reference Case Projection for the Residential Sector, Broken Out by the End Uses Considered in This Analysis

6.1 AEO 2008 Reference Case Projection for the Combined Commercial and Residential Sectors, Broken Out by the End Uses Considered in This Analysis........................................ 6.2

6.2 Integrated Commercial and Residential End Uses Represented in the BT BAU Case................ 6.5

6.3 Integrated Commercial and Residential End Uses Represented in the BT Lost Opportunities Case

6.4 Integrated Commercial and Residential End Uses Represented in the BT BAU Case.

6.5 Integrated Commercial and Residential End Uses Represented in the BT Lost Opportunities Case.

6.6 Integrated Commercial and Residential End Uses Represented in the BT BAU Case......

6.7 Integrated Commercial and Residential End Uses Represented in the BT Lost Opportunities Case.

8.12025 Buildings Sector Energy Flow from Source to End Use

8.2 2025 Buildings Sector Energy Flow from Source to End Use under the BT Lost Opportunities Case

8.3 Change in 2025 Buildings Sector Energy Flows between AEO 2008 Reference Case and the BT Lost Opportunities Case. 


\section{Tables}

2.1 Primary Energy Consumption and Savings by Analysis Case ….......................................... 2.2

2.2 Comparison of Study Results....................................................................................... 2.4

3.1 Treatment of Commercial End Uses in the Lost Opportunities Case ....................................... 3.1

4.1 Treatment of Residential End Uses in the Lost Opportunities Case ......................................... 4.1

4.22001 Housing Unit Ownership by Weatherization Eligibility ................................................. 4.4

5.1 Commercial Sector Performance Assumptions ................................................................ 5.5

5.2 Residential Sector Performance Assumptions ..................................................................... 5.7

6.1 Comparison of Forecasted AEO 2008 Reference Case Commercial Sector End Use

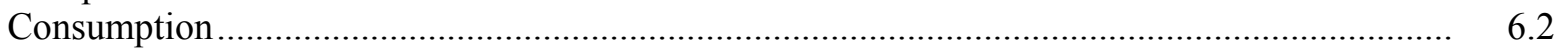

6.2 Comparison of Forecasted AEO 2008 Reference Case Residential Sector End Use

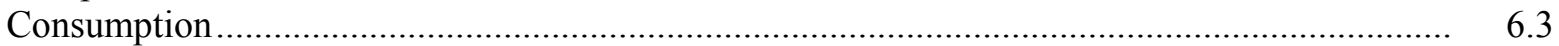

6.3 Lost Opportunities Case Energy Savings by Commercial End Use and Vintage, Site QBtu in 2025

6.4 Lost Opportunities Case Energy Savings by Residential End Use and Stock Vintage, Site

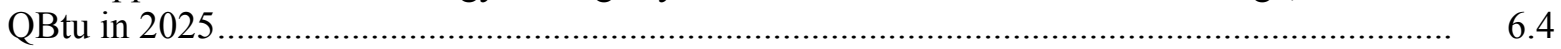

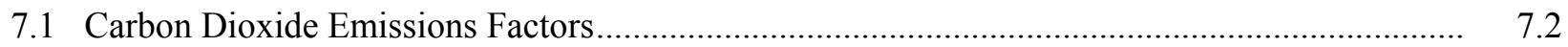

7.2 Annual Carbon Dioxide-Equivalent Emissions Impacts ....................................................... 



\subsection{Introduction}

This report summarizes the results and the assumptions used in an analysis of the potential "lost efficiency opportunities" in the buildings sector. These targets of opportunity are those end-uses, applications, practices, and portions of the buildings market that are not currently being addressed, or addressed fully, by the US Department of Energy (DOE) through its Building Technologies Program (BTP), due to lack of resources. The lost opportunities, while a significant increase in effort and impact in the buildings sector, still represent only a small portion of the full technical potential for energy efficiency in buildings. Such national-scale benefits will not be realized without a more aggressive national program, and are thus "lost opportunities" if not captured now. It is much more cost-effective to realize profound improvements in building performance at the time of construction; once a building is constructed, it is not cost effective to realize similar levels of performance, and thus the opportunities are "lost."

BTP commissioned Pacific Northwest National Laboratory (PNNL) to estimate the potential impacts on national energy consumption in the year 2025 from a greatly expanded commercial and residential sector portfolio. PNNL first was directed to analyze the lost opportunities in the residential buildings sector, which resulted in an initial internal white paper $^{1}$ on the expected impacts in terms of energy and carbon. After completing that analysis, the request was expanded to include a separate analysis of the commercial buildings sector. That analysis resulted in an Official Use Only publication ${ }^{2}$ illustrating the potential implications of failing to pursue an aggressive research portfolio, using an integrated analysis of potential research programs. That white paper demonstrated the ability to consider the integrated impacts of a portfolio of activities. PNNL's previous analyses (many years of annual budget benefits estimates) of energy and carbon impacts associated with detailed BTP activities have necessarily been "unintegrated" or individually estimated impact assessments produced for BTP's internal use and are pre-decisional in nature. However, PNNL has developed an approach to estimating the integrated contribution of many research activities spanning many end-uses. Therefore, BTP has commissioned this report which expands the approach used for the commercial sector to include the residential sector and provides integrated energy and carbon impacts across BTP's span of influence in the buildings sector.

Based on discussions with BTP, PNNL postulated and analyzed a greatly expanded buildings sector program that would aggressively pursue an integrated program of research, demonstration, and deployment of improved technologies for the commercial and residential sectors. Through the integration of measures targeting major energy service demands including space conditioning, water heating, and lighting, the energy performance of new additions to the stock and some element of the existing stock would be greatly improved. Further, BTP would target increased energy-efficiency in what the Energy Information Administration (EIA) terms the "other" 3 (and sometimes "miscellaneous") end uses. Finally, the zero-energy concepts currently being developed in the commercial and residential sectors would be more aggressively integrated and packaged for deployment in the new stock, leading to wide adoption of solar photovoltaic (PV) technology in buildings.

\footnotetext{
${ }^{1}$ J.A. Dirks, D.M. Anderson, D.J. Hostick, D.B. Belzer, K.A. Cort, Feb. 2007, Lost Opportunities in the Residential Sector: Draft Analysis and Results, PNNL-16455. This document was superseded by the current document.

${ }^{2}$ J.A. Dirks, D.M. Anderson, D.J. Hostick, D.B. Belzer, K.A. Cort, Oct. 2007, Lost Opportunities in the Commercial Sector: Draft Analysis and Results, PNNL-SA-57697. This document was superseded by the current document.

${ }^{3}$ Per EIA, Annual Energy Outlook 2008, Table 5, Footnote 6: "includes miscellaneous uses, such as service station equipment, automated teller machines, telecommunications equipment, medical equipment, pumps, emergency generators, combined heat and power in commercial buildings, manufacturing performed in commercial buildings, and cooking (distillate fuel oil), plus residual fuel oil, liquefied petroleum gas, coal, motor gasoline, and kerosene."
} 
This analysis presents the effects of pursuing reductions in energy use and carbon emissions through technology research activities. It does not consider alternative pathways which could lead to the same end. For example, disruptive changes in service demands could alter the landscape of opportunities for end use technology development. Such disruptions might occur if viable alternative technologies for achieving the same level of comfort emerge or gain strongholds (for example, hand disinfectant replacing hand washing with water, advances in clothing technology to "space condition" the person in hot or cold built environments, increased task illumination vs. room illumination, increased application of microwave technology for cooking, ultrasonic dishwashing and showering technologies, open-air clothes drying, etc.)

Because of the necessarily hypothetical nature of the requested analysis, PNNL relied heavily on professional judgment, derived in part from PNNL's experience in estimating national-scale energy savings impacts as part of the Government Performance and Results Act (GPRA) benefits estimation process. PNNL staff also drew on its experience estimating the energy efficiency potential at Army bases and other federal facilities. 


\subsection{Results Summary}

The effects of the Lost Opportunities (LO) case are best illustrated using Figure 2.1. The top line of the figure shows building energy consumption as projected by EIA in the Annual Energy Outlook 2008 (AEO) Reference Case. ${ }^{4}$ In the Reference Case, EIA projects combined commercial and residential sector primary energy use to be 47.7 QBtu in 2025 . As Table 2.1 indicates, over $70 \%$ of the projected growth is commercial. The bottom line in Figure 2.1 indicates the technical potential for energy savings if the outcomes from BTP technologies in the Lost Opportunities analysis were adopted instantaneously at $100 \%$ levels. Just below the top line is the business as usual (BAU) case for BTP, developed from PNNL's analysis of the FY 2009 budget request ${ }^{5}$; that is, the current effort in research and development, codes and standards, and deployment given current resources. PNNL projects that this current or BAU BTP program will result in energy consumption levels which are $6.9 \%$ lower than the Reference Case by 2025. With the activities defined in the more aggressive Lost Opportunities case (third line from the top); primary energy consumption would be $17.8 \%$ lower than the Reference Case in 2025. Total energy savings are estimated to be 8.5 primary QBtu (3.3 QBtu BAU plus an additional 5.2 QBtu Lost Opportunities) by 2025. In perspective, 8.5 QBtu is about equal to the total primary energy consumed by the state of California annually. ${ }^{6}$ These results are summarized in Table 2.1 below. Note that each successive savings level reported in Table 2.1 incorporates savings reported in the previous case. That is, the "Lost Opportunities" case assumes all the savings from the Building Technologies (BT) BAU case and adds to these additional opportunities for savings.

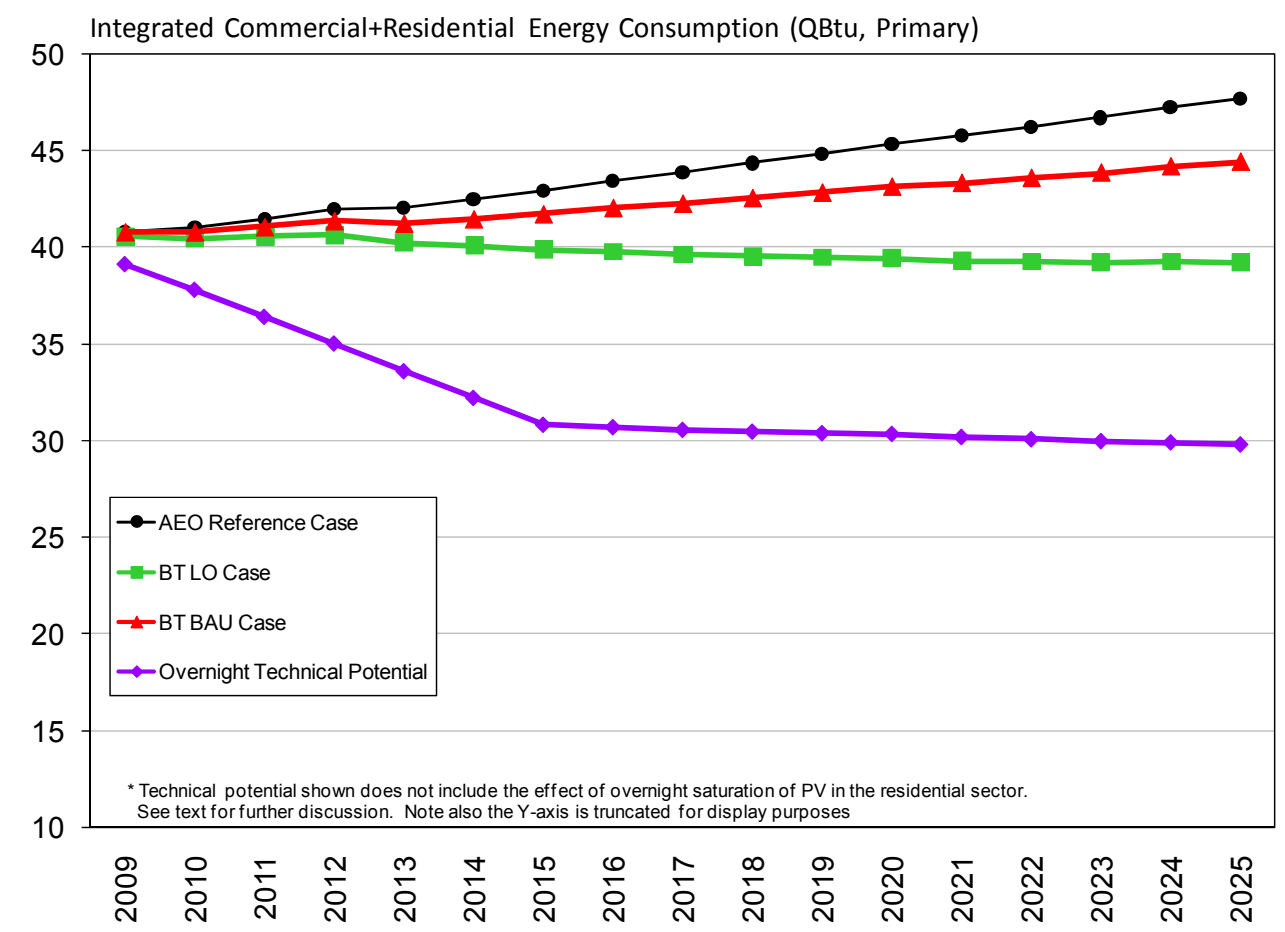

Figure 2.1. Total Estimated Buildings-Sector Energy Consumption under Alternative Cases

\footnotetext{
${ }^{4}$ The lost opportunities case should not be compared to the full AEO Reference Case commercial and residential energy consumption, because not all end uses included in the AEO commercial and residential sectors are expected to be addressed by BTP. This is further clarified in Tables 4 and 5. The baseline for comparison is a subset of the AEO commercial and residential sectors - excluding only very minor end uses.

${ }^{5}$ OMB Budget of 9/21/2007.

${ }^{6}$ Table S3. Energy Consumption Estimates by Source, 2005, http://www.eia.doe.gov/emeu/states/sep_sum/html/sum btu tot.html.
} 
Table 2.1. Primary Energy Consumption and Savings by Analysis Case (QBtu)

\begin{tabular}{lrrrrrr}
\hline Analysis Case & 2009 & 2015 & 2025 & 2009 & 2015 & 2025 \\
\hline AEO Reference Case - Commercial & 18.6 & 20.3 & 23.5 & \multicolumn{2}{c}{ Savings Relative to the } \\
AEO Reference Case - Residential & 22.2 & 22.6 & 24.2 & \multicolumn{2}{c}{ AEO Reference Case } \\
Buildings Sector Reference Case & 40.8 & 42.9 & 47.7 & & & \\
BT BAU Case - Commercial & 18.6 & 20.2 & 22.4 & 0.0 & 0.2 & 1.2 \\
BT BAU Case - Residential & 22.2 & 21.6 & 22.1 & 0.0 & 1.0 & 2.1 \\
Buildings Sector BAU Case & 40.8 & 41.7 & 44.4 & 0.0 & 1.2 & 3.3 \\
BT LO Case - Commercial & 18.5 & 19.1 & 19.6 & 0.1 & 1.3 & 3.9 \\
BT LO Case - Residential & 22.1 & 20.8 & 19.6 & 0.1 & 1.8 & 4.6 \\
Buildings Sector LO Case & 40.6 & 39.9 & 39.2 & 0.2 & 3.0 & 8.5 \\
Technical Potential - Commercial & 18.0 & 15.4 & 15.4 & 0.6 & 4.9 & 8.2 \\
Technical Potential - Residential & 21.1 & 15.4 & 14.5 & 1.1 & 7.2 & 9.7 \\
Buildings Sector Technical Potential & 39.1 & 30.8 & 29.8 & 1.7 & 12.1 & 17.9 \\
\hline *Totals affected by rounding. & \multicolumn{7}{c}{} \\
\hline
\end{tabular}

The results show that an aggressive program in the buildings sector, represented by the Lost Opportunities case, could result in decreasing energy consumption through the projection period. The BAU case could hold combined residential and commercial consumption nearly level through the period - increasing slightly in the out years. However, the legacy of the existing stock and the associated barriers to implementation of aggressive energy savings measures in the other end uses causes a wide gap to remain between the Lost Opportunities case and technical potential case. Projected beyond 2025, the divergence from the AEO Reference Case forecast increases, as the new post-2008 buildings gain a greater and greater share of the total stock. See Figure 2.2 and Figure 2.3 for context.

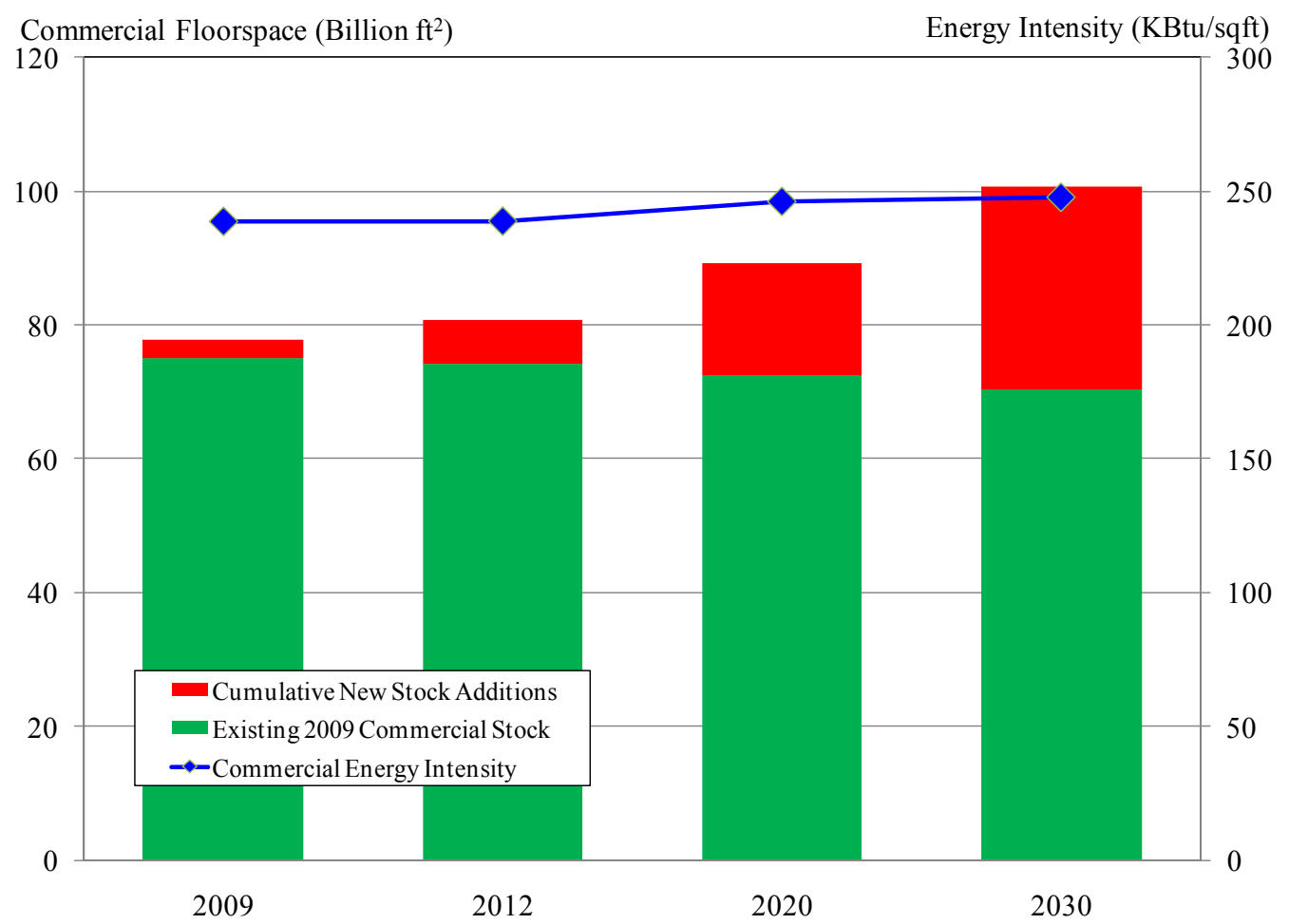

Figure 2.2. New and Existing Commercial Floorspace, 2008-2030, (AEO 2008 Reference Case) 


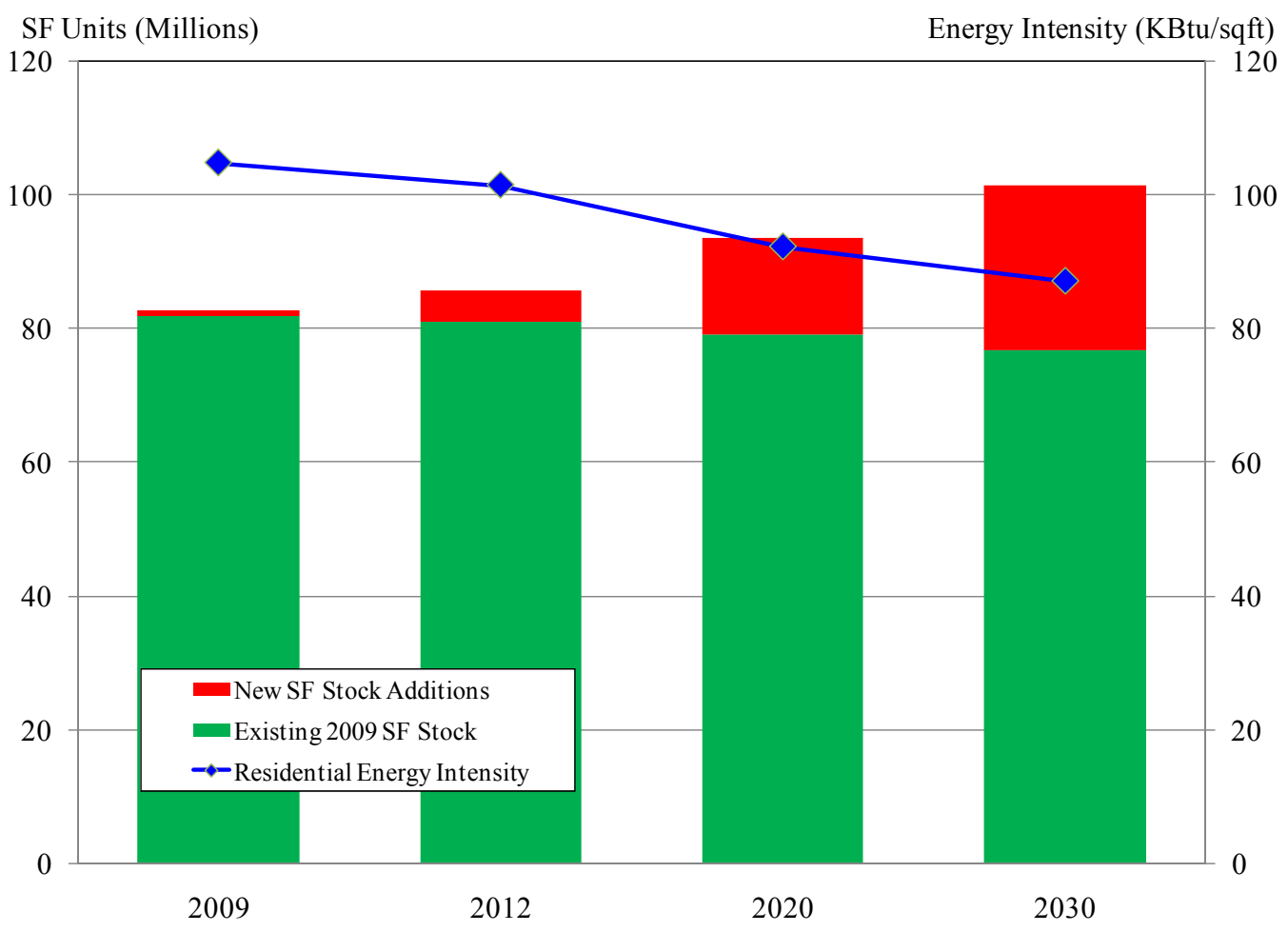

Figure 2.3. New and Existing Housing Stock, 2008-2030, (AEO 2008 Reference Case) Analysis Methodology

\subsection{Comparisons with Other Studies}

Two previous national studies conducted in the last 10 years ask similar questions (i.e. what are the potential energy and carbon savings still to be harvested from the buildings sector?), though each is unique in approach and nuance of the policy question. Chapter 4 of the Clean Energy Futures ${ }^{7}$ study (CEF) of 2000 covers the buildings sector and focuses on the specific policy levers available to affect wider adoption of advanced building technologies. These effects were estimated by adjusting consumer discount rates using a special version of the National Energy Modeling System (NEMS) named CEFNEMS, a deterministic model of the US commercial and residential sectors. A Pew Center report ${ }^{8}$ from $^{-}$ 2005 provides a thorough survey of the policy literature to assess the potential energy and carbon savings in the near and long term. That study is based on the "10-50" solution to climate change, which suggests that the climate change problem needs to be resolved in the next 50 years by providing solutions in each decade.

Both of these studies provide summarized results that may be useful for general comparison with this study. While general comparisons are useful for gaining an understanding of convention wisdom about efficiency opportunities in the buildings sector, differences in methodological approaches make statistical comparisons between the studies invalid. Both the cited studies and this study use deterministic

\footnotetext{
${ }^{7}$ Interlaboratory Working Group. 2000. Scenarios for a Clean Energy Future (Oak Ridge, TN; Oak Ridge National Laboratory and Berkeley, CA; Lawrence Berkeley National Laboratory), ORNL/CON-476 and LBNL-44029, November. Available online at: http://www.ornl.gov/sci/eere/cef/ ${ }^{8}$ Brown, M.A., F. Southworth, T.K. Stovall, 2005, Towards a Climate-Friendly Built Environment, prepared for the Pew Center on Global Climate Change, Oak Ridge National Laboratory, June, 2005. Available online at: http://www.pewclimate.org/docUploads/Buildings_FINAL.pdf
} 
approaches which do not provide statistical confidence intervals around the reported results. We are not aware of any national study of the buildings sector that addresses uncertainty in a quantitative fashion. Table 2.2 provides some illustrative comparisons of results for discussion purposes.

Table 2.2. Comparison of Study Results

\begin{tabular}{lcccc}
\hline \multicolumn{1}{c}{ Study } & $\begin{array}{c}\text { Baseline Annual } \\
\text { Energy Savings } \\
(\text { QBtu, Primary })\end{array}$ & $\begin{array}{c}\text { Baseline Annual } \\
\mathrm{CO}_{2} \text { Savings } \\
(\mathrm{GtCO})\end{array}$ & $\begin{array}{c}\text { Projected Annual } \\
\text { Energy Savings } \\
(\text { QBtu, Primary })\end{array}$ & $\begin{array}{c}\text { Projected Annual } \\
\mathrm{CO}_{2} \text { Savings } \\
\left(\mathrm{GtCO}_{2}\right)\end{array}$ \\
\hline $\begin{array}{l}\text { Lost Opportunities } \\
(\text { Out year=2025) }\end{array}$ & 0.20 & 0.0149 & 8.5 & 0.5117 \\
$\begin{array}{l}\text { Clean Energy Future } \\
(\text { Out year=2020) }\end{array}$ & $\mathrm{NA}$ & $\mathrm{NA}$ & 8.2 & 0.8983 \\
$\begin{array}{l}\text { Pew Center } \\
(\text { Out year=2025) }\end{array}$ & 0.21 & 0.0132 & 4.2 & 0.2603 \\
\hline
\end{tabular}

Several important considerations affect these comparisons. First, this study has overcome some known traditional analytical problems not handled in the comparison studies, including the modeling of overlapping end uses and the modeling of electricity dispatch and its associated fuel mix impacts. Second, the set of measures considered in each of the studies may not be comparable. For example, this study models technology research advances that could be expected under greatly enhanced federal investment as integrated activities, and incorporates associated deployment activities by assumption. The other studies focus more on the market mechanisms that could be employed to affect wide adoption of technologies. Therefore, the comparison provided is illustrative only of the magnitude of impacts that would be reasonably achievable given significantly expanded federal investment

\footnotetext{
${ }^{9}$ Interlaboratory Working Group. 2000, Op Cit; CO2 savings were converted from reported carbon savings

${ }^{10}$ Brown, M.A., F. Southworth, T.K. Stovall, 2005, Op Cit; CO2 savings were converted from reported carbon savings
} 


\subsection{Commercial Sector Approach}

To capture potential energy savings in a very "deep and broad" efficiency case, the impetus for this analysis, PNNL established aggressive commercial performance targets including improved shell (building envelope and structural elements), better heating, ventilation and air conditioning (HVAC) mechanical performance, two to three times more efficient lighting, and holding energy intensity constant in various miscellaneous end uses. Table 3.1 illustrates the end uses addressed in Lost Opportunities Case.

Table 3.1. Treatment of Commercial End Uses in the Lost Opportunities Case

\begin{tabular}{|c|c|c|}
\hline AEO End Use & Lost Opportunity End Use & $\begin{array}{c}\text { Percent of } 2025 \text { AEO } \\
2008 \text { Reference Case } \\
\text { Commercial Primary } \\
\text { Energy Use }\end{array}$ \\
\hline Space Heating & Heating & $8.56 \%$ \\
\hline Space Cooling & Cooling & $7.67 \%$ \\
\hline Water Heating & Water Heating & $5.29 \%$ \\
\hline Ventilation & $\begin{array}{l}\text { Not explicitly addressed, but decreased in proportion to } \\
\text { heating/cooling load reduction }\end{array}$ & $2.88 \%$ \\
\hline Cooking & Not Addressed & $1.80 \%$ \\
\hline Lighting & Lighting & $16.83 \%$ \\
\hline Refrigeration & Refrigeration & $3.49 \%$ \\
\hline Office Equipment (PC) & Office Equipment (PC) & $4.35 \%$ \\
\hline $\begin{array}{l}\text { Office Equipment } \\
\text { (non-PC) }\end{array}$ & $\begin{array}{l}\text { Office Equipment } \\
\text { (non-PC) }\end{array}$ & $11.39 \%$ \\
\hline \multirow[t]{2}{*}{ Other Uses } & Other Uses & $37.75 \%$ \\
\hline & Sum of Above & $100.0 \%$ \\
\hline
\end{tabular}

In addition to the principal building end uses for commercial, PNNL assumed that refrigeration and office equipment end uses would be targeted under a more robust research and development (R\&D) program. We assumed refrigeration would follow the same percentage reductions as cooling equipment through some combination of $R \& D$ advances and regulatory standards. This would be equivalent to a about a 23\% decrease in 2015 and a 35\% decrease in 2025 below EIA projections.

For office equipment, EIA assumptions contained in the AEO reference case suggest that the number of both personal computer (PC) and non-PC related office equipment will increase in absolute terms and in intensity as measured by energy use per square foot. In our analysis, we assume that technological innovation creates increasing efficiency levels in all non-PC office equipment. As such, as increases in floor space result in increased numbers of office equipment, the related increases in energy consumption are offset by higher efficiencies. For PC office equipment, we assumed that the delivered electricity consumption would be flat over time. As a result, given that floor space is increasing, energy intensity per square foot is actually assumed to decrease; and while overall energy use rises, it is not as dramatic as in the EIA reference case. For PC-related office equipment, this would be equivalent to a $7.5 \%-23.1 \%$ decrease (2015-2025) in energy use as compared with EIA projections of delivered electricity for this end-use. For non-PC office equipment, this outcome would be equivalent to a 15\%-25\% decrease (20152025) over EIA projections. The Lost Opportunities case does not directly address cooking or ventilation end uses. 
What remains to be addressed is "Other" commercial end uses. A large component of the "Other" end uses in the commercial sector comes from non-building uses for such things as inter-basin water transport (moving water from one river basin to another for environmental, agricultural, and fisheries benefits). According to TIAX $^{11}$, just three inter-basin water transfer projects account for $20 \%$ of all US water pumping energy consumption. Public water distribution and waste water treatment also are significant electric loads assigned by EIA to the commercial sector but not within the programmatic mandate or addressed by BTP as "buildings-related" energy use. Such non-building end uses are not addressed under the Lost Opportunities case. Appendix A provides amplified discussion of the "Other" end use services.

Figure 3.1 illustrates commercial sector component energy use as projected in the AEO 2008 reference case. According to AEO 2008, the average annual growth in commercial primary energy consumption, from 2006 through 2030 is $0.6 \%$ for water heating, $0.2 \%$ for space heating, $0.8 \%$ for space cooling, $0.7 \%$ for lighting, $1.7 \%$ for other uses, $2.1 \%$ for PC office equipment, and $3.3 \%$ for nonPC office equipment. While significantly enhanced BTP activities may address the traditional end uses (space conditioning, water heating, and lighting), it is unclear what sort of program can be formulated to address these "Other" end uses. If energy efficiency programs, companies, and individuals do not have specific knowledge as to what is included in "Other" and how further energy savings might be attained within this area, these "other" end use services will dominate future commercial energy consumption. This is especially true as the zero energy buildings approach reduces space conditioning, water heating, and lighting loads down dramatically.

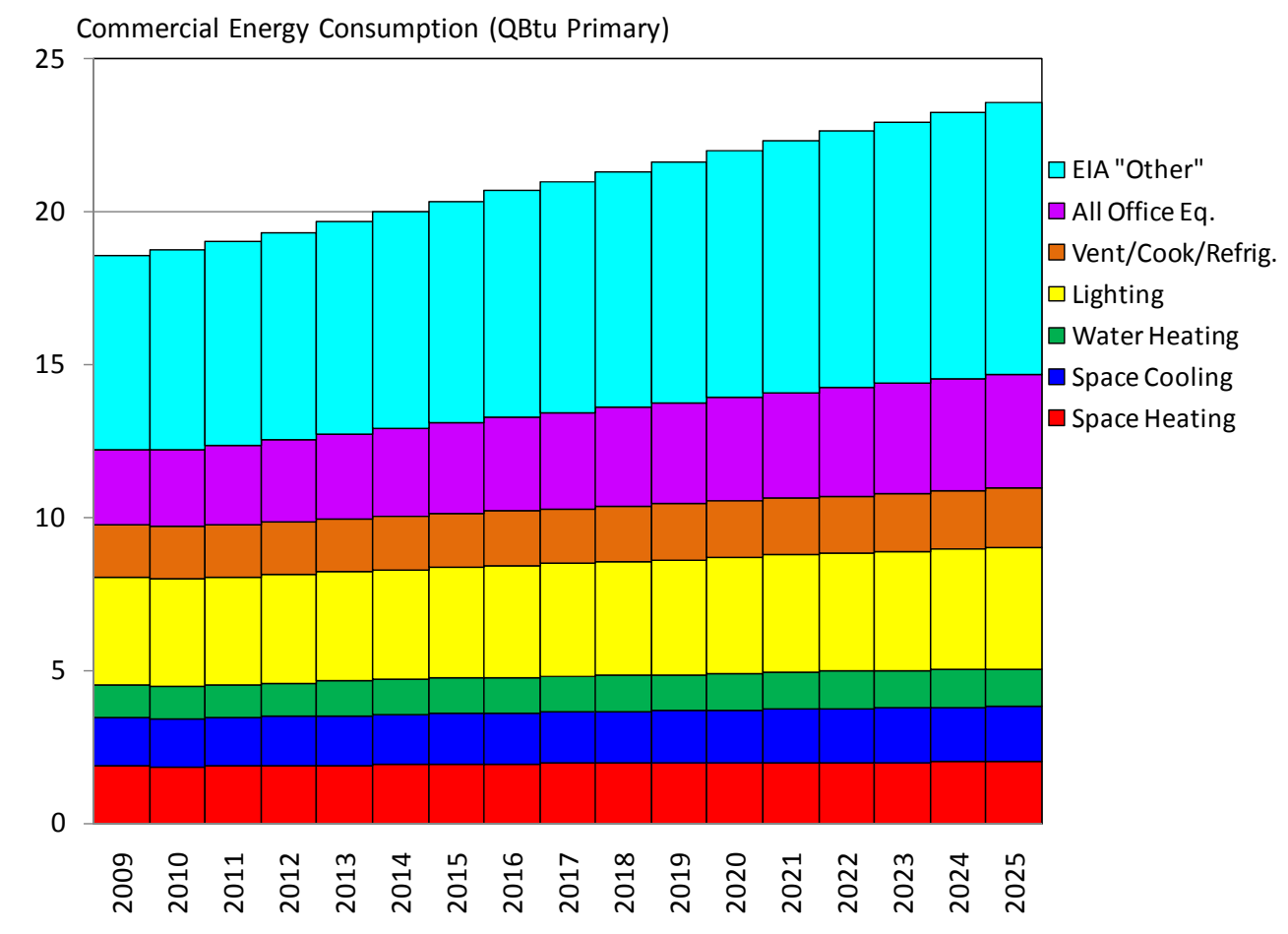

Figure 3.1. AEO 2008 Reference Case Projection for the Commercial Sector, Broken Out by the End Uses Considered in This Analysis

\footnotetext{
${ }^{11}$ See discussion section and technical memo attachment discussing the TIAX work in this area.

TIAX 2006, Commercial and Residential Sector Miscellaneous Electricity Consumption: Y2005 and Projections to 2030. Prepared for the US Department of Energy, Energy Information Administration, Reference No. D0366, TIAX LLC, Cambridge, MA
} 
It would appear that there are two principal categories of energy use (though largely undefined) which are lumped into the "other" by EIA:

- Non-building-related commercial-sector energy consumption (water treatment and storage, for example)

- An attempt to address a statistical discrepancy between the EIA supply-survey estimates for electricity (as produced by EIA for the State Energy Data System and published in the Annual Energy Review) and the Commercial Building Energy Consumption Survey (CBECS) estimates of total commercial building energy use.

Energy consumption attributable to both of these categories falls outside the scope of energyefficiency opportunities that BT expects to address. See Appendix A for further investigation into the nature of the "Other" end use category.

\subsection{Commercial Penetration Rate Development}

PNNL assumed that an aggressive technology R\&D program targeting both higher performance and reasonable first cost would be accompanied by an aggressive program of market conditioning and deployment activities to facilitate timely and significant market penetration of the research outcomes. This assumption guides the development of market penetration parameters discussed below. Because of the hypothetical nature of the requested analysis, PNNL relied heavily on analytical conventional wisdom and employed reasonable technological extrapolations in the view of the authors. For purposes of this analysis, the commercial market was divided into existing and new, with consideration given to the segmentation by owned-leased space and by non-government/government-owned. The market penetration potential is explained in the succeeding sections on the existing and new commercial markets, followed by a summary of the resulting overall penetration rates.

In developing market penetration rates for the Lost Opportunities exercise, PNNL assumed that an increase in funding would also fund aggressive deployment and outreach activities. In the process, PNNL considered possible activities that could be undertaken to increase market penetration, drawing from a variety of sources to inform the process and provide high, but reasonable, boundaries. These sources included historical successes of BTP-funded activities such as those that developed and promoted low-e windows, compact fluorescent lights, and advanced refrigeration (as detailed in publications such as 'Energy Research at DOE: Was it worth it? ${ }^{12}$ ), market studies and characterizations (including the Innovologie report ${ }^{13}$, U.S. Department of Energy publications, U.S. Department of Education publications, Builderonline.com), and surveys (including the Johnson Controls report, Residential Energy Consumption Survey (RECS), CBECS - see footnotes throughout). Historical experiences provided the basis for judgement as to the impact of technologies and practices that transformed the market. Market studies and characterizations informed decisions as to what was possible within market segments (e.g., low-income, education), and surveys provided insights as to what has been done historically with respect to energy efficient technologies and practices, and what decision-makers are considering for the future.

\footnotetext{
12 National Research Council, 2001, Energy Research at DOE - Was it Worth it: Energy Efficiency and Fossil Energy Research 1978 to 2000 , National Academy Press, Washington, DC.

13 John Reed, Katherine Jonson, et al. Who Plays and Who Decides: The Structure and Operation of the Commercial Building Market. Innovologie, LLC, March 2004. http://www.eere.energy.gov/buildings/highperformance/pdfs/who plays who decides.pdf
} 


\subsubsection{Existing Commercial Market}

There is a great deal of concentration of ownership in the commercial building sector for all building types. Commercial building owners and franchisers are typically large national and regional firms. Seventy six percent of commercial floorspace is non-government owned; and of this total, approximately $50 \%$ is occupied by the owners. ${ }^{14}$ Based on information provided by Innovologie ${ }^{15}$ in 2004 , most owneroccupied arrangements would seemingly have financial incentives to increase energy efficiency in buildings and reduce energy use; however, an effective strategy to promote the deployment of energyefficiency building equipment, designs and retrofits in the commercial sector requires that these designs are set very early in the design process and prior to the completion of financing. Once the budget is set, it is difficult to introduce new components, even if they provide energy efficiency benefits and a stream of future dollar savings.

It is likely that most commercial entities will be able to substantially upgrade the energy-efficiency of heating and cooling systems as they replace older equipment, in fact changes in underlying equipment energy standards will dictate it. However, in order to commit resources to substantial and energyefficient envelope and lighting retrofits, the profit margins must be at a level to support these higher first costs of renovation. Most commercial buildings are small. Typically, the facility-management knowledge of these smaller commercial establishments and the sophistication of the strategies being used to deal with facility-related matters are not high.

While these factors can adversely impact the potential within the existing commercial market, there are some factors that increase the potential opportunity for retrofits: ${ }^{16}$

- About 50 percent of commercial office lease space is managed by the top 50 property managers.

- The top 40 lodging firms (and their affiliates) own about $70 \%$ of the market.

- About $12 \%$ of restaurant chains are owned or franchised by 25 firms.

- Fifty convenience store chains own or franchise about $40 \%$ of the convenience stores.

- The top 50 warehousing firms control about $8 \%$ of the total warehouse space, with the top 10 companies accounting for about $3.7 \%$ of the U.S. total.

Additionally, a survey conducted by Johnson Controls of 1,250 commercial energy management decision makers ${ }^{17}$ found that:

- About $60 \%$ of respondents expect to make energy efficiency improvements funded from their operating budget or capital expenditures in the next year, expecting to invest an average of $6 \%-8 \%$ of those budgets.

- They expect to use an average of $8 \%$ less energy as a result of those anticipated investments.

\footnotetext{
${ }^{14}$ EIA, Commercial Buildings Energy Consumption Survey 2003, Table C1 http://www.eia.doe.gov/emeu/cbecs/cbecs2003/detailed tables 2003/2003set5/2003html/b18.html

${ }^{15}$ Reed, et al. Op. Cit.

16 Ibid.

${ }^{17}$ Energy Efficiency Indicator Research Final Report. Johnson Controls. May 17, 2007.

http://johnsoncontrolseei.web180.com/files/energy_efficiency_indicator_report.pdf
} 
- About $77 \%$ of respondents with current or planned retrofit or new construction projects believe that energy efficiency is (or will be) a priority in the construction design.

- About $64 \%$ of companies have a tolerance for a 2-5 year payback period for return on energy efficiency investments.

Of the Johnson Controls respondents who already have energy management measures in place, most measures have been low cost (e.g., educating staff on ways to reduce energy use [70\%], adjusting HVAC controls to reduce on-time [60\%], attending energy management seminars [31\%]). More capital-intensive measures installed included:

- $67 \%$ switched to energy efficient lighting.

- $31 \%$ upgraded their existing energy management system.

- $28 \%$ installed energy-saving glass in windows.

- $28 \%$ replaced inefficient equipment even though it was not due for replacement.

- $28 \%$ installed variable speed or frequency drives (VSD, VFD).

- $23 \%$ installed an energy management system.

- $13 \%$ re-roofed with white shingles to reduce heat gain.

- $10 \%$ self-generate power to use during demand peaks.

While the Johnson Controls study is promising in terms of the number of companies undertaking individual measures at the current time, we are not aware of similar statistics as to how many are implementing multiple measures. The measures assumed in this report for existing buildings are not individual, but represent a package that includes both window replacements and HVAC upgrades. Given these factors, it is possible that significant gains could be made in the existing commercial building market with an aggressive campaign focusing on the top property owners and managers. PNNL therefore assumed potential market penetration of $20 \%$ of non-government owned space due to BT efforts.

Twenty four percent of the commercial stock is government-owned. Government-owned buildings are predominantly locally-owned (CBECS 2003, Table C1), and just over $50 \%$ of total governmentowned space is used for education (these buildings are either state-owned, or locally-owned, comprising about $58 \%$ of state and locally-owned floorspace). Federally-owned buildings must meet certain legislative drivers (e.g., EPAct 2005, Executive Order 13423) regarding energy efficiency, and the Office of Energy Efficiency and Renewable Energy (EERE)'s Federal Energy Management Program (FEMP) is tasked with assisting federal agencies in this effort, therefore we assumed that no federally-owned building energy savings would be due to BT efforts. Within the non-education buildings at the state and local levels, there may be state and local legislation, as well as other federal programs (such as the State Energy Program) that potentially overlap with BT's efforts. Within this segment, we estimate that BT efforts would increase market penetration by an additional $10 \%$.

Within the remaining public education buildings, there are many efforts underway to target the potential within this sector. In addition to BT's Energy Smart Schools program, the Environmental Protection Agency (EPA) is also promoting energy efficiency in schools through their Energy Star for Higher Education and Energy Star for K-12 School Districts programs. The same legislative drivers impacting state and local public buildings may also include education buildings. Additionally, the U.S. Green Building Council's Leadership in Energy and Environmental Design (LEED) Green Building Rating System has developed a specific LEED for Schools rating system $(20 \%$ of the LEED certified 
green buildings are schools and universities), and the Collaborative for High Performance Schools (CHPS), which started in California in 2000, has been adopted by 14 school districts in California, as well as three other states, and plans are under way to bring CHPS to five more states. ${ }^{18}$ While green buildings do not necessarily target energy efficiency specifically, they do include energy efficiency as a component, and may be responsible for energy reductions of up to $40 \% .{ }^{19}$ Moreover, a Department of Education Study ${ }^{20}$ found that about $47 \%$ of public school districts renovated or retrofitted existing facilities to improve energy efficiency in FY 2001 (although no statistics as to measures undertaken were provided).

While there are a number of activities targeting the education submarket, there are great gains to potentially be realized. Because the top 100 school districts enroll about $23 \%$ of all K-12 students, the market is similar to the commercial sector as a whole, in terms of concentration or "consolidation" of school districts. ${ }^{21}$ Given these factors, it is possible that gains could also be made in the existing education market with an aggressive campaign focusing on the largest school districts. PNNL therefore assumed potential market penetration of $15 \%$ of public education space due to BT efforts.

\subsubsection{New Commercial Market}

In the near term, one can expect new commercial construction to be similar to recent construction; however, past experience and emerging trends in the commercial market indicate that the commercial buildings of the future will be different, from design to construction to use. The Innovologie report identified technological and organizational changes in the areas of communications, energy, transportation, nanotechnology and biotechnology, manufacturing, and materials as the drivers for these emerging trends. Additionally, changes in consumer values to focus more on time, convenience, and cost, will continue to have a greater impact on the built environment (for example, consider the impact of online shopping to the warehouse and retail sub-markets, or the rise in telecommuting to the office submarket).

In the future, new buildings will need to be designed and constructed with these changes in mind. The Johnson Controls survey indicated that $77 \%$ of respondents with current or planned retrofit or new construction projects believe that energy efficiency is (or will be) a priority in the building design; BT has the potential opportunity to play a large role in the process. While many of these respondents will be considering component changes, BT's efforts can promote and promulgate whole-building efficiency guidelines that might not otherwise be considered, either due to a lack of awareness or current higher first costs. Additionally, the Johnson Controls survey found that almost $80 \%$ of respondents believe that energy prices will increase over the next 12 months, with the average expectation of an increase of over $13 \%$. For these reasons, PNNL assumed that an aggressive BT campaign could result in market penetration of $60 \%$ in non-governmental owned space. Because these same drivers may also impact the lease market in terms of options that lessees will be taking into consideration, PNNL expects that a percentage of new buildings built to lease will consider the energy-efficiency implications in an effort to make their buildings more attractive to potential lessees. PNNL therefore assumed that $20 \%$ of the nongovernmental lease market will wholly adopt the suite of advanced technologies and practices.

\footnotetext{
${ }^{18}$ McGraw-Hill Construction. Education Green Building SmartMarket Report. 2007.

${ }^{19}$ Ibid.

${ }^{20}$ National Center for Education Statistics, U.S. Department of Education. Effects of Energy Needs and Expenditures on U.S. Public Schools. May 2003.

${ }^{21}$ Reed, et al. Op. Cit.
} 
PNNL's assumptions for new government-owned non-education buildings are the same as that for existing buildings; that $10 \%$ of the penetration of non-federally owned non-education buildings would be due to BT efforts. Because of the potential legislative drivers and number of other players within the public education energy efficiency market, PNNL assumed that an aggressive BT campaign could result in market penetration of $40 \%$ in public education space.

\subsubsection{Market Penetration Summary}

Total estimated penetration into the commercial market is therefore assumed to be:

\section{Commercial Existing}

(76\% non-government owned $\times 50 \%$ owner-occupied $\times 20 \%$ penetration)

plus

(76\% non-government owned $\times 50 \%$ leased $\times 20 \%$ penetration)

plus

( $3 \%$ federally-owned $\times 0 \%$ penetration $)$

plus

$(21 \%$ government owned $\times 42 \%$ non-education $\times 10 \%$ penetration $)$

plus

( $21 \%$ government owned $\times 58 \%$ education $\times 15 \%$ penetration)

Which resolves to $7.6 \%+7.6 \%+0 \%+0.9 \%+1.8 \%$

$=17.9 \%$ of existing commercial floorspace by 2025 .

Commercial New

(76\% non-government owned $\times 50 \%$ owner-occupied $\times 60 \%$ penetration)

plus

(76\% non-government owned $\times 50 \%$ leased $\times 20 \%$ penetration)

plus

( $3 \%$ federally-owned $\times 0 \%$ penetration)

plus

( $21 \%$ government owned $\times 42 \%$ non-education $\times 10 \%$ penetration $)$

plus

( $21 \%$ government owned $\times 58 \%$ education $\times 40 \%$ penetration $)$

Which resolves to $22.8 \%+7.6 \%+0 \%+0.9 \%+4.9 \%$

$=36.2 \%$ of new commercial floorspace by 2025 . 



\subsection{Residential Sector Approach}

For the lost opportunities case, PNNL developed two sets of performance characteristics to represent future houses: the first set characterizes households in 2015; the second set characterizes households in 2025. The technical potential forecast assumed $100 \%$ penetration in both new and existing households for the years 2015 and 2025 to develop the potential savings for those years. The technical potential case for 2008 was the same as the reference case, and the points in between were interpolated linearly. Technical potential bounds the results, and the activities estimated to result from the greatly expanded residential sector investment would be expected to fall somewhere between the current AEO baseline, and the technical potential. Penetration rates, as described in a section below, were applied to the technical potential savings in order to determine the lost opportunities savings.

PNNL focused on major (and growing) end-uses including space heating, space cooling, water heating, lighting, and plug loads. To capture the potential, residential performance targets were based on an integrated electric heat pump that serves both space conditioning and water heating loads, more efficient lighting, general improvements to the building shell, and improvements in plug loads. Table 4.1 illustrates the end uses addressed in Lost Opportunities Case.

Table 4.1. Treatment of Residential End Uses in the Lost Opportunities Case

\begin{tabular}{|c|c|c|c|}
\hline End Use & AEO End Use & $\begin{array}{c}\text { Lost Opportunity End } \\
\text { Use }\end{array}$ & $\begin{array}{c}\text { Percent of } 2025 \\
\text { AEO2008 Reference } \\
\text { Case Residential Primary } \\
\text { Energy Use }\end{array}$ \\
\hline Clothes Dryers & Clothes Dryers & Not Addressed & 3.95 \\
\hline Clothes Washers* & Clothes Washers & Not Addressed & 0.34 \\
\hline Color Televisions & Color Televisions & Miscellaneous & 4.48 \\
\hline Cooking* & Cooking & Not Addressed & 2.90 \\
\hline Dishwashers & Dishwashers & Not Addressed & 1.30 \\
\hline FA Furnace Fans & FA Furnace Fans & Not Addressed & 0.98 \\
\hline Freezers & Freezers & Not Addressed & 1.31 \\
\hline Lighting & Lighting & Lighting & 6.07 \\
\hline Computer Monitors & Personal Computers & Miscellaneous & 0.39 \\
\hline Desktop PCs & Personal Computers & Miscellaneous & 1.20 \\
\hline Laptops & Personal Computers & Miscellaneous & 0.18 \\
\hline Refrigeration* & Refrigeration & Not Addressed & 4.84 \\
\hline Space Cooling & Space Cooling & Space Cooling & 12.59 \\
\hline Space Heating & Space Heating & Space Heating & 25.67 \\
\hline Water Heating & Water Heating & Water Heating & 10.67 \\
\hline Coffee Makers & Other & Miscellaneous & 0.21 \\
\hline Electric Spas & Other & Miscellaneous & 0.45 \\
\hline Home Audio Eq. & Other & Miscellaneous & 0.53 \\
\hline Microwave Ovens & Other & Miscellaneous & 0.70 \\
\hline Set-top Boxes & Other & Miscellaneous & 1.69 \\
\hline \multirow[t]{2}{*}{ All Other End Uses } & Other & Not Addressed & 19.56 \\
\hline & & Sum of Above & 100.00 \\
\hline
\end{tabular}


Similar to the discussion of Figure 3.1 and the commercial sector, Figure 4.1 illustrates residential sector component energy use as projected in the AEO 2008 reference case. According to AEO 2008, the average annual growth in residential primary energy consumption, from 2006 through 2030 is $0.1 \%$ for water heating, $0.6 \%$ for space heating, $1.2 \%$ for space cooling, $-1.9 \%$ for lighting, $1.9 \%$ for other uses, $2.0 \%$ for color televisions and set-top boxes, and 3.5\% for personal computers. Per Annual Energy Outlook 2008 Table 4, 88\% of "other" is electric "other." 22 National estimates of stand-by power consumption for these devices were gathered from two reports commissioned by DOE and completed by TIAX LLC ${ }^{23,24}$, and inform this analysis regarding the potential energy savings from an aggressive research program to reduce stand-by losses attributable to these devices under the Lost Opportunities case.

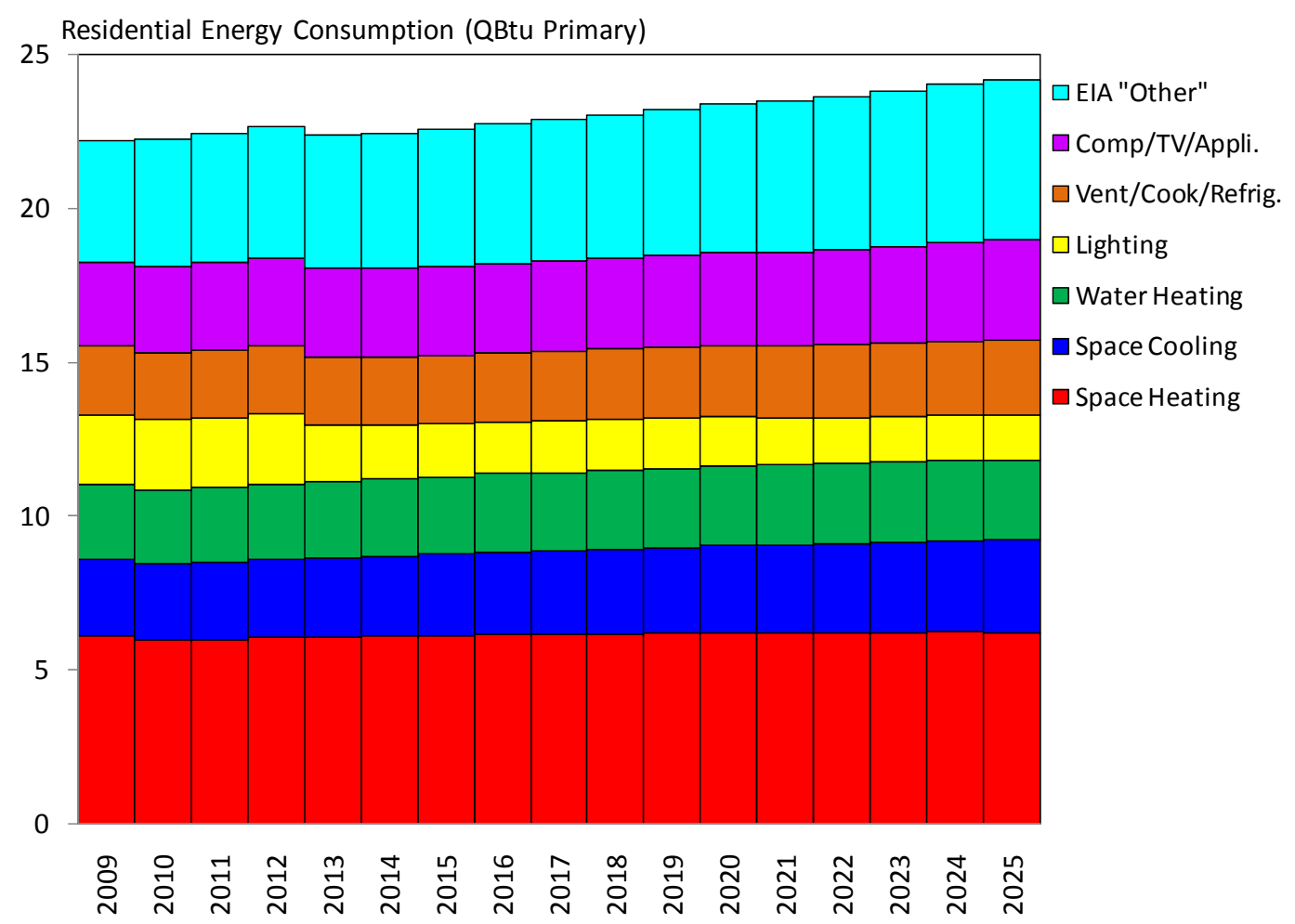

Figure 4.1. AEO 2008 Reference Case Projection for the Residential Sector, Broken Out by the End Uses Considered in This Analysis

\subsection{Residential Penetration Rate Development}

PNNL assumed that an aggressive technology R\&D program would be accompanied by an aggressive program of market conditioning and deployment activities to facilitate timely and significant market penetration of the research outcomes. This theory guided the development of market penetration parameters discussed below. Because of the hypothetical nature of the requested analysis, PNNL relied heavily on analytical conventional wisdom and employed reasonable technological extrapolations in the view of the authors.

\footnotetext{
${ }^{22}$ Defined by EIA to include "small electric devices, heating elements, and motors not included in end-uses shown in Table 4."

${ }^{23}$ Commercial and Residential Miscellaneous Electricity Consumption: Y2005 and Projections to 2030, TIAX Report \#D0366, September, 2006.

${ }^{24}$ U.S. Residential Information technology Energy Consumption, TIAX Report, March, 2006.
} 


\subsubsection{New Residential Market}

Based on information provided in Builder Online Top 100 Builder statistics, we assumed that a greatly enhanced BT residential program that targets the top builders, upgrades components in the builder supply chain, and possibly induces mortgage financing incentives, could result in capturing $60 \%$ of the sub-market for new single-family homes. In 2005, the top 10 single-family builders built almost $21 \%$ of all single-family housing, and Builder Online reports that some forecasters are projecting that the top 10 builders could capture as much as $50 \%$ of the market in the next 5-10 years (the top builder provided about $3 \%$ of all new starts). ${ }^{25}$ Because much of the production of the manufactured (factory built as opposed to site built) homes sub-market is concentrated in a few builders (the top builder provided approximately $20 \%$ of new manufactured housing units), it would also be possible to capture a large percentage of the new manufactured market by partnering with the top builders. As such, we assume that an aggressive campaign could result in $70 \%$ of the mobile and manufactured home market. The multifamily builder market is much less consolidated than the other two sub-markets (the top ten builders built about $12 \%$ of all multi-family units), and has less potential, or at least greater difficulty, in achieving large market penetration. Therefore, we assume that an aggressive campaign with multifamily builders would impact $30 \%$ of the market.

\subsubsection{Existing Residential Market}

The existing residential market is much more difficult to influence and penetrate than new homes. The opportunity for retrofit (e.g., window replacements) and change out of systems (e.g., water heaters and appliances) is more limited. The opportunity to influence whole building energy-saving designs in existing homes is essentially zero. Furthermore, affordability becomes a factor. Approximately $32 \%$ of existing residential households are considered "Federally Eligible" for economic assistance with energy bills and high-end upgrades or major retrofits are not likely for these households. ${ }^{26}$ Home remodeling expenditures are significantly concentrated in high-value homes of $\$ 400,000$ or more. In 2003 , over $40 \%$ of the expenditures for residential additions were completed for these high-end homes, though they represent only about $10 \%$ of the total owner-occupied housing stock. ${ }^{27}$

PNNL assumed that BT would sponsor research aggressively targeting the existing residential stock (primarily, but not limited to single-family) by developing shell retrofit technologies that would be modular and cost effective to install. Research would result in new membranes, siding materials, sealants, insulation materials, and other technologies that could be packaged in modular panels that could either be placed over the existing envelope or attached to the shell at the time of siding or window replacement. Further, BT would sponsor market acceptance and other deployment-type activities to facilitate relatively wide adoption in the residential market. Additionally, while developed for the retrofit market, these products would also improve the cost effective performance of new structures.

PNNL assumes that only 10\% of lower-income homeowners would upgrade HVAC, lighting, and windows if products are cost-competitive. The remaining homeowners are assumed to be four times more likely to make major change to systems, including HVAC, lighting fixtures, and windows. ${ }^{28}$ Given other factors in the replacement market for multifamily (e.g., diversity of envelope types and building materials,

\footnotetext{
${ }^{25} \mathrm{http}: / /$ www.builderonline.com/content/builder100/builder100.asp?sectionID $=228$ \&year $=2005$

262004 Buildings Energy Databook, U.S. Department of Energy, Table 7.1.2

${ }^{27}$ The Changing Structure of the Home Remodeling Industry, Improving America's Housing 2005. Joint Center for Housing Studies of Harvard University.

${ }^{28}$ Housing Characteristics 1993. DOE/EIA-0314(93) (1995).
} 
centralized HVAC systems) and mobile homes (e.g., constraints on wall width and height), we assume that owners in these categories are less likely to implement major changes to systems. Therefore, multifamily penetration is assumed to be half that of single-family; and manufactured home penetration is assumed to be one-tenth of single-family.

It is also possible that an aggressive campaign targeting non-owner occupied multi-family buildings could result in some increased market penetration. PNNL assumed that an aggressive campaign that included Rebuild America, changes in general code requirements, low- or no-interest loans, and specific code requirements for multi-family buildings where a significant percentage of the tenants were federally eligible could result in $10 \%$ penetration of this group.

Approximately $48 \%$ of households eligible for federal assistance are owner-occupied (of a total 33.8 million households), and approximately $77 \%$ of the other households are owner-occupied (of a total 73.2 million households). ${ }^{29}$ Table 4.2 breaks these out by building type.

Table 4.2. 2001 Housing Unit Ownership by Weatherization Eligibility (million households)

\begin{tabular}{lccccccc}
\hline & \multicolumn{2}{c}{ Single-family } & \multicolumn{2}{c}{ Multifamily } & \multicolumn{2}{c}{ Mobile Home } \\
& Own & Rent & Own & Rent & Own & Rent \\
\hline Federally Eligible & 12.8 & 5.0 & 0.9 & 11.8 & 2.6 & 0.7 \\
Federally Ineligible & 50.4 & 5.5 & 3.0 & 10.8 & 3.1 & 0.4 \\
& 63.2 & 10.5 & 3.9 & 22.6 & 5.7 & 1.1 \\
Totals & \multicolumn{2}{c}{73.7} & \multicolumn{2}{c}{26.5} & \multicolumn{2}{c}{6.8} \\
\hline
\end{tabular}

Total estimated penetration into the existing market is therefore assumed to be:

Single-family (SF)

$(24 \%$ Federally Eligible $[(12.8+5.00) / 73.7] \times 72 \%$ Owner $[12.8 /(12.8+5.0)] \times 10 \%$ penetration $)$ plus $(76 \%$ Federally ineligible $[50.4+5.5) / 73.7] \times 90 \%$ Owner $[50.4 /(50.4+5.5)] \times 40 \%$ penetration $)$

which resolves to $1.7 \%+27.3 \%$

$=29.1 \%$ of existing $S F$ homes by 2025 .

Multifamily (MF)

$(48 \%$ Federally Eligible $\times 7 \%$ Owner $\times 5 \%$ penetration $)$

plus

$(48 \%$ Federally Eligible $\times 93 \%$ Non-Owner $\times 10 \%$ penetration $)$

plus

(52\% Federally Ineligible $\times 22 \%$ Owner $\times 20 \%$ penetration)

which resolves to $0.2 \%+4.5 \%+2.3 \%$

$=6.9 \%$ of existing MF homes by 2025 .

${ }^{29} 2006$ Building Energy Databook, U.S. Department of Energy, Table 7.1.7 


\section{Mobile Home (MH)}

$(49 \%$ Federally Eligible $\times 79 \%$ Owner $\times 1 \%$ penetration $)$

plus

$(51 \%$ Federally Ineligible $\times 89 \%$ owner $\times 4 \%$ penetration $)$

which resolves to $0.4 \%+1.8 \%$

$=2.2 \%$ of existing $M H$ homes by 2025 .

Consistent with PNNL's FY08 benefits analysis, and past GPRA work, the penetration rate forecasts PNNL used in this analysis were developed using diffusion curves as documented in Elliott et al, $2004{ }^{30}$ These diffusion curves describe a rate and path of market penetration over time from initial level to the eventual maximum. Traditionally, these curves follow an S shape with penetration starting slow, then increasing rapidly, and finally leveling off at some maximum rate of penetration.

${ }^{30}$ Elliott, D.B., D.M. Anderson, D.B. Belzer, K.A. Cort, J.A. Dirks, D.J. Hostick. 2004. Methodological Framework for Analysis of BuildingsRelated Programs: The GPRA Metrics Effort. PNNL-14697. Pacific Northwest National Laboratory, Richland, Washington. http://www.pnl.gov/main/publications/external/technical_reports/PNNL-14697.pdf 



\subsection{Analysis Methodology}

The Lost Opportunities analysis was conducted using the Facility Energy Decision System (FEDS) model to estimate space conditioning loads ${ }^{31}$ and PNNL's Building Energy Analysis Modeling System (BEAMS) model to estimate savings ${ }^{32}$. The analysis begins by developing an adjusted AEO 2008 reference case for the commercial and residential sectors with sufficient detail that it includes components actually addressed under the lost opportunities case. For example, using AEO 2008, Tables 5.1 and 5.2, we assembled the reference-case commercial and residential energy consumption at the end-use level including space heating, space cooling, water heating, lighting, etc. Next, we estimated technical potential energy consumption levels, based on an instantaneous market adoption of all the technologies and practices represented in the Lost Opportunities case. These changes in technologies and practices are assumed to result from a greatly expanded Building Technology Program in areas including research, integration, market acceptance, and deployment activities such as codes and standards.

PNNL developed two sets of performance characteristics to represent future buildings: the first set characterizes buildings in 2015; the second set characterizes buildings in 2025 . The technical potential forecast assumed 100\% penetration in both new and existing buildings for the years 2015 and 2025 to estimate potential energy savings. The technical potential case for 2009 was the same as the reference case, and the years in between were interpolated linearly. Technical potential bounds the results, and the activities estimated to result from the greatly expanded commercial and residential sector investment would be expected to fall somewhere between the current BTP BAU baseline, and the technical potential. Penetration rates, as described in a section below, were applied to the technical potential savings in order to determine the Lost Opportunities savings. In this analysis, PNNL used the FEDS model to calculate building loads for 7200 commercial buildings representing 10 building types, 6 floor areas, 8 vintages, and 15 weather cities for the years 2009, 2015, and 2025. For the residential sector, PNNL used the FEDS model to analyze loads for 2835 buildings covering 15 climate zones, 3 building types, 9 floor areas, and 7 vintages for the years 2009, 2015, and 2025. Hence over 30,000 building simulations were run to calculate the Lost Opportunities loads.

In summary, PNNL estimated two program cases:

- BTP "Business as Usual," reflected by the prospective benefits estimated for the activities funded by the FY 2009 budget request, as noted above

- "Lost Opportunities" incorporating a much more aggressive and expanded effort in the commercial and residential buildings sectors.

PNNL relied on professional analytical judgment to determine the assumed performance characteristics as incorporated in the modeling approach. We picked performance characteristics that we believed to be achievable without specifically choosing individual technologies. For example we assumed an R60 roof in 2025 for new single family homes without concerning ourselves with how this would be developed, the actual technical specifications, or the programs used to gain market acceptance.

\footnotetext{
${ }^{31}$ Pacific Northwest National Laboratory. 2002. Facility Energy Decision System User's Guide, Release 5.0. PNNL-10542, Rev. 3, Richland, Washington.

${ }^{32}$ Elliott DB, DM Anderson, DB Belzer, KA Cort, JA Dirks, and DJ Hostick. 2004. Baseline Inputs for BEAMS: Data used in preparing Methodological Framework for Analysis of Building-Related Programs: The GPRA Metrics Effort, June 2004. PNNL-14696, Pacific Northwest National Laboratory, Richland, WA Available at: http://www.pnl.gov/main/publications/external/technical_reports/PNNL-14696.pdf
} 
While we are silent as to the actual technologies and other actions BTP might choose to achieve this level of performance in the market, the underlying assumption is that similar levels of energy and carbon saving potential would result.

As a specific example of PNNL's exercise of analytical judgment, we did the following in our analysis of dynamic windows (dynamically shaded windows):

- We analyzed all buildings with a shading coefficient of 0.53 (Solar Heat Gain Coefficient [SHGC] of 0.461) and took the heating loads from this run. We analyzed all buildings with a shading coefficient of 0.21 (SHGC 0.183) and used these for the cooling loads. The resulting values of the SHGC we used are not the program goal minimum (0.08-0.06) and maximum $(0.58-0.60)$, but are in fact more representative of average values that would occur during cooling and heating periods throughout the year ${ }^{33}$.

- Integrated net sales penetration into the north and south for new construction and existing commercial buildings

$-\quad 2009-1.7 \%$

$-\quad 2015-23.3 \%$

$-\quad 2025-51.1 \%$

- Integrated net sales penetration into the north and south for new construction and existing residential buildings ${ }^{20}$

$-\quad 2009-0.7 \%$

$-\quad 2015-9.3 \%$

$-\quad 2025-20.4 \%$

\subsection{Challenges}

Traditional benefits analysis suffers from the inability to easily sum benefits across activities and measures that target the same end use. In this analysis an approach has been developed to estimate integrated energy benefits for any and all activities affecting the buildings sector. Absent a rigorous and costly building simulation approach, a series of informed assumptions can be made to reduce the complexity of the approach by setting boundary limits to the effects from given technologies and thus to allow consideration of these technologies in an integrated fashion.

The analytical approach is bounded by the issues both in designing and implementing an integrated program to address energy use in buildings, and the estimation of the impacts of that effort. The major issues are as follows:

- System interactions are large and pervasive. For example, the lighting program is forecasting dramatic increases in lighting system efficacy and high rates of market penetration. This will significantly decrease cooling loads and increase heating loads. Concurrent with the decrease in internal gains is an improvement in envelope component $U$-values for single family homes and a simultaneous increase in home size. All these factors result in a requirement for some level of building simulation. 
- There is overlap among BT programs. While multiple paths to the same goal increase the likelihood of achieving the goals, it is recognized that in many case all paths cannot be achieved simultaneously. For example, BT has programs promoting and developing low-e, dynamic, and highly insulating windows; the sum of the market penetration goals exceeds the available market. Hence, market penetration rates must be adjusted to realistic integrated values.

Another challenge to the analysis of this program is differences in market penetration. Market penetration rates vary:

- Across building type (e.g., highly insulating window are only targeting residential buildings)

- By vintage (e.g., the advance envelope program in only looking at new single family homes)

- By climate zone or geographic region (e.g., the current penetration of low-e windows is highly dependent on climate as well as whether it is a window for a new building or a replacement).

\subsection{Current BTP Activities}

Under the BAU case, BTP would expect to produce a stream of energy savings benefits for the nation. PNNL's formal estimation of these benefits for the FY 2009 budget was finalized in the fall of 2007 and is contained in Appendix B. Our analysis of these benefits informs this analysis. These BAU activities would not stop or be replaced under the Lost Opportunities case, but instead, added to these efforts would be those activities initiated under the lost opportunities case. So as not to double count these BAU impacts, PNNL netted out the effect of the accelerated uptake of technologies in the lost opportunities case already accounted for in BAU activities. PNNL then added the remainder of energy savings under the BAU case to the result of the lost-opportunities-specific case. The integration of BAU activities proceeded as outlined.

\section{General}

- All heating and cooling loads are calculated in FEDS with the reduced internal gains associated with the reduction in lighting and "other" loads.

\section{Residential Envelope}

- In this analysis, three residential building types are employed. For a single window technology in the existing stock and across each building type, heating and cooling loads are determined for 9 different floor areas by 6 different vintages by 15 different climates. The FEDS runs are weighted and combined based on population data to obtain heating and cooling loads for each building type by North and South. Each successive technology is analyzed in a similar fashion (although for electrochromic windows we calculate the heating and cooling separately). Finally, resulting North and South heating and cooling loads are weighted by the market penetration function values get the combined effect of all technologies.

- Three current BTP activities affect new single family opaque envelope: Next Generation Roof, Advanced Walls, and Next Generation Materials. Combined impacts of these programs and associated penetration rates were used to develop integrated opaque envelope u-values. Penetrations are relatively modest in 2015 and more aggressive in 2025 resulting in integrated average wall uvalues $\left(\mathrm{Btu} / \mathrm{hr} \cdot \mathrm{ft}^{2} \cdot \mathrm{F}^{\circ}\right)$ across all new single-family construction of 0.0494 and 0.0337 in 2015 and 
2025 respectively. Similarly, integrated average roof u-values across all new single-family construction are 0.0329 . and 0.0243 in 2015 and 2025 respectively.

- In addition to the opaque envelope, there are three relevant Windows R\&D activities: highly insulating, electrochromics, and Energy Star windows. For residential, where penetration of Energy Star windows is already large, it is assumed that highly insulating and electrochromics compete against Energy Star.

- Building simulations were run to calculate loads for highly insulating (three varieties), electrochromics (heating and cooling run separately as explained in the Analysis Methodology section), Energy Star (four regions), and double-pane clear. Each set of loads was estimated independently by FEDS (assuming 100\% penetration), and the results of these 113,400 runs were combined based on the penetration rates.

Commercial Envelope

- For commercial it is assumed that electrochromics and Energy Star compete against each other and that both combined market share penetrates against double-pane clear.

- Loads for electrochromics (heating and cooling run separately as explained in the Analysis Methodology section), Energy Star (four regions), and double-pane clear were each calculated independently (and assuming 100\% penetration) by FEDS and then the results of these 100,800 runs were combined based on the penetration rates.

\subsection{Lost Opportunities Technology Performance Assumptions}

PNNL focused the analysis on major (and growing) end-uses including space heating, space cooling, water heating, lighting, and several others (see Tables 3.1 and 4.1). Performance characteristics (efficiency levels) expected to result from R\&D activities are included in Table 5.1 and Table 5.2. PNNL developed these performance assumptions through literature review, peer collaboration, and with internal review by BTP staff. PNNL garnered insight from the National Renewable Energy Laboratory (NREL) "Technical Potential of Zero Energy Buildings"33 report. We also secured a peer review of the technology assumptions contained in this report from Navigant Consulting. The assumptions were also distributed to BTP staff for review.

To illustrate the approach, consider window technologies. As with all technologies in this report we do not specify what the actual technology is, rather, we piece together information from various sources to project a likely outcome under substantially increased federal funding. Note that all window performance characteristics are actually the BTP research goals at current levels of federal investment. That said, U-values of $0.1 \mathrm{BTU} / \mathrm{hr} / \mathrm{ft}^{2}$ or less are not only theoretically achievable but have been commercially available for decades using suspended film technology. Southwall Technologies has developed and licensed this technology and offers an Insulating Glass Unit (IGU) Performance (U-value) of $0.08 \mathrm{BTU} / \mathrm{hr} / \mathrm{ft}^{2}$ for their Superglass Quad IGUs (www.southwall.com). Alpen Windows (www.alpeninc.com) uses this technology to produce R-15 window units (U-values of $0.067 \mathrm{BTU} / \mathrm{hr} / \mathrm{ft}^{2}$ ), where the R-value is measured as the "weighted average of sash, frame, glass and edge-of-glass performance."

${ }^{33}$ Griffith B, N Long, P Torcellini, and R Judkoff. 2007. Assessment of the Technical Potential for Achieving Net Zero-Energy Buildings in the Commercial Sector. Final Report. National Renewable Energy Laboratory. 
Table 5.1. Commercial Sector Performance Assumptions

\begin{tabular}{|c|c|c|c|c|c|}
\hline $\begin{array}{l}\text { Commercial } \\
\text { Buildings }\end{array}$ & $\begin{array}{r}\text { Time Frame: } \\
\text { Vintage: }\end{array}$ & $\begin{array}{l}2015 \\
\text { New }\end{array}$ & $\begin{array}{c}2015 \\
\text { Existing }\end{array}$ & $\begin{array}{l}2025 \\
\text { New }\end{array}$ & $\begin{array}{c}2025 \\
\text { Existing }\end{array}$ \\
\hline \multirow{6}{*}{ Specifications } & $\begin{array}{l}\text { Window U-Value }\left(\mathrm{Btu} / \mathrm{h} \bullet \mathrm{ft}^{2} \bullet{ }^{\circ} \mathrm{F}\right)[\mathrm{U} \text {-value is for the complete window assembly-- } \\
2015 \text { value is DOE goal] }\end{array}$ & 0.1 & 0.1 & 0.07 & 0.07 \\
\hline & $\begin{array}{l}\text { Roof Total R-Value }\left(\mathrm{h} \cdot \mathrm{ft}^{2} \bullet{ }^{\circ} \mathrm{F} / \mathrm{Btu}\right)[\mathrm{R} \text {-value is for roof/ceiling or wall and includes } \\
\text { framing members--assumes new materials development] }\end{array}$ & 50 & 40 & 60 & 50 \\
\hline & Wall Total R-Value $\left(\mathrm{h} \bullet \mathrm{ft}^{2} \bullet{ }^{\circ} \mathrm{F} / \mathrm{Btu}\right)[\mathrm{R}$-value is for perimeter (slab assumed)] & 40 & 30 & 50 & 40 \\
\hline & Floor Total R-Value $\left(\mathrm{h} \bullet \mathrm{ft}^{2} \bullet{ }^{\circ} \mathrm{F} / \mathrm{Btu}\right)[\mathrm{R}$-value is for perimeter (slab assumed)] & 10 & 10 & 10 & 10 \\
\hline & $\begin{array}{l}\text { Ventilation ( } \mathrm{ft}^{3} / \text { occupant)/Infiltration (air changes /hour) [ } 20 \mathrm{ft}^{3} / \text { occupant } \\
\text { infiltration assumption is the same as residential for existing and less for new] }\end{array}$ & $20 / 0.2$ & $20 / 0.4$ & $20 / 0.2$ & $20 / 0.4$ \\
\hline & $\begin{array}{l}\text { Average Lighting Efficacy (lumens/Watt) [Fluorescent technology still dominates } \\
\text { in 2015; efficacy improvements during this timeframe are largely incandescents } \\
\text { being replaced with solid state lighting (SSL). In the } 2025 \text { timeframe all lighting } \\
\text { technologies are being replaced by SSL (savings include increases in daylighting)] }\end{array}$ & 80 & 70 & 160 & 140 \\
\hline \multirow{5}{*}{$\begin{array}{l}\text { Percentage } \\
\text { Changes in } \\
\text { Intensity }\end{array}$} & $\begin{array}{l}\text { Service Hot Water Load (\% change over baseline) [Flow reduction (e.g., low flow } \\
\text { faucets), reduced run time (e.g. passive infra-red activated faucets), insulating pipe } \\
\text { runs (new buildings)] }\end{array}$ & $-15 \%$ & $-10 \%$ & $-30 \%$ & $-20 \%$ \\
\hline & $\begin{array}{l}\text { Refrigeration [Thermotunneling cooling, } \mathrm{CO}_{2} \text { refrigerants, Light Emitting Diode } \\
\text { (LED) lighting, and other DOE programs will help commercial refrigeration.] }\end{array}$ & $-22.7 \%$ & $-22.7 \%$ & $-35.0 \%$ & $-35.0 \%$ \\
\hline & $\begin{array}{l}\text { Office Equipment (PC) [Efficiency improvements are expected to result in flat } \\
\text { consumption at } 2008 \text { levels; hence, energy use intensity would fall for the segment. } \\
\text { This is dramatically different than AEO's assumption.] }\end{array}$ & $-6.3 \%$ & $-6.3 \%$ & $-21.6 \%$ & $-21.6 \%$ \\
\hline & $\begin{array}{l}\text { Office Equipment (non-PC) [Efficiency improvements are expected to } \\
\text { counterbalance proliferation; hence, energy use intensity would remain constant for } \\
\text { the segment. This is dramatically different than AEO's assumption.] }\end{array}$ & $-15.6 \%$ & $-15.6 \%$ & $-25.0 \%$ & $-25.0 \%$ \\
\hline & $\begin{array}{l}\text { Other Uses [Efficiency improvements are expected to counterbalance proliferation; } \\
\text { hence, energy use intensity would remain constant for the segment. This is } \\
\text { dramatically different than AEO's assumption.] }\end{array}$ & $-5.1 \%$ & $-5.1 \%$ & $-12.7 \%$ & $-12.7 \%$ \\
\hline
\end{tabular}


Table 5.1. (contd)

\begin{tabular}{|c|c|c|c|c|c|}
\hline $\begin{array}{l}\text { Commercial } \\
\text { Buildings }\end{array}$ & $\begin{array}{r}\text { Time Frame: } \\
\text { Vintage: }\end{array}$ & $\begin{array}{l}2015 \\
\text { New }\end{array}$ & $\begin{array}{c}2015 \\
\text { Existing }\end{array}$ & $\begin{array}{l}2025 \\
\text { New }\end{array}$ & $\begin{array}{c}2025 \\
\text { Existing }\end{array}$ \\
\hline $\begin{array}{l}\text { Group } 1 \\
\text { (Dynamic } \\
\text { Windows) }\end{array}$ & $\begin{array}{l}\text { Window Shading Coefficient [Shading coefficient assumes }>70 \% \text { visible light } \\
\text { transmission; first value is heating season second value is cooling season. Note that } \\
\text { DOE goals for shading coefficients for dynamic windows are } 0.667 \\
\text { (maximum)/0.092 (minimum) for } 2015 \text { and } 0.690 \text { (maximum)/0.069 (minimum) for } \\
2025 \text {. The values used in the simulations were taken from NREL's Commercial } \\
\text { Sector Assessment: Part } 3 \text { Technical Potential for Achieving Net-Zero-Energy } \\
\text { Buildings. The VT goal is not met in the cooling mode] }\end{array}$ & $0.53 / 0.21$ & $0.53 / 0.21$ & $0.53 / 0.21$ & $0.53 / 0.21$ \\
\hline $\begin{array}{l}\text { Group } 2 \\
\text { (Static Windows) }\end{array}$ & $\begin{array}{l}\text { Window Shading Coefficient [Shading coefficient assumes }>70 \% \text { visible light } \\
\text { transmission; first value is North second is South] }\end{array}$ & $0.7 / 0.3$ & $0.7 / 0.3$ & $0.7 / 0.2$ & $0.7 / 0.2$ \\
\hline \multirow{9}{*}{$\begin{array}{l}\text { Equipment } \\
\text { Performance }\end{array}$} & Cooling packaged unit (seasonal coefficient of performance) & 6.15 & 6.15 & 7.33 & 7.33 \\
\hline & Cooling Chiller (seasonal coefficient of performance) & 7.46 & 7.46 & 8.88 & 8.88 \\
\hline & Heating (heating season performance factor) - Heat Pump (Electric) & 3.17 & 3.17 & 3.81 & 3.81 \\
\hline & Heating (Gas and Oil) & $94 \%$ & $94 \%$ & $96 \%$ & $96 \%$ \\
\hline & Energy Recovery Ventilation Percent Saving - Cooling & $5 \%$ & $5 \%$ & $5 \%$ & $5 \%$ \\
\hline & Energy Recovery Ventilation Percent Saving - Heat Pump & $20 \%$ & $20 \%$ & $20 \%$ & $20 \%$ \\
\hline & Energy Recovery Ventilation Percent Saving - Heat (Gas \& Oil) & $35 \%$ & $35 \%$ & $35 \%$ & $35 \%$ \\
\hline & Service hot water (energy factor) - Heat Pump (Electric) & 2 & 2 & 3 & 3 \\
\hline & $\begin{array}{l}\text { Service hot water (energy factor) - Gas Condensing (Based on Esource Report ER- } \\
06-12^{34} \text {, not significantly different than instantaneous WH) }\end{array}$ & $86 \%$ & $86 \%$ & $88 \%$ & $88 \%$ \\
\hline
\end{tabular}

\footnotetext{
34 Esource Member Report ER-06-12: Innovation in the Residential Water Heating Sector Bubbles Over: Gas Tankless and Condensing Units Improving but Still Costly
} 
Table 5.2. Residential Sector Performance Assumptions

\begin{tabular}{|c|c|c|c|c|c|}
\hline All Residential: & $\begin{array}{r}\text { Time Frame: } \\
\text { Vintage: }\end{array}$ & $\begin{array}{l}2015 \\
\text { New }\end{array}$ & $\begin{array}{r}2015 \\
\text { Existing }\end{array}$ & $\begin{array}{l}2025 \\
\text { New }\end{array}$ & $\begin{array}{r}2025 \\
\text { Existing }\end{array}$ \\
\hline \multirow{12}{*}{ Specifications: } & $\begin{array}{l}\text { Window U-Value }\left(\mathrm{Btu} / \mathrm{h} \cdot \mathrm{ft}^{2} \bullet{ }^{\circ} \mathrm{F}\right)- \\
\mathrm{U} \text {-value is for the complete window assembly }\end{array}$ & 0.1 & 0.1 & 0.05 & 0.05 \\
\hline & $\begin{array}{l}\text { Window Shading Coefficient }- \\
\text { Shading coefficient assumes }>70 \% \text { visible light transmission; first value is North, } \\
\text { second is South }\end{array}$ & $0.7 / 0.3$ & $0.7 / 0.3$ & $0.7 / 0.2$ & $0.7 / 0.2$ \\
\hline & $\begin{array}{l}\text { Roof Total R-Value }\left(\mathrm{h} \cdot \mathrm{ft}^{2} \cdot{ }^{\circ} \mathrm{F} / \mathrm{Btu}\right)- \\
\mathrm{R} \text {-value is for roof/ceiling or wall and includes framing members }\end{array}$ & 50 & 40 & 60 & 50 \\
\hline & $\begin{array}{l}\text { Wall Total R-Value }\left(\mathrm{h} \cdot \mathrm{ft}^{2} \bullet{ }^{\circ} \mathrm{F} / \mathrm{Btu}\right)- \\
\mathrm{R} \text {-value is for flooring and includes framing members (crawlspace assumed) }\end{array}$ & 40 & 30 & 50 & 40 \\
\hline & $\begin{array}{l}\text { Floor Total R-Value }\left(\mathrm{h} \bullet \mathrm{ft}^{2} \bullet{ }^{\circ} \mathrm{F} / \mathrm{Btu}\right)- \\
0.35 \text { is assumed to be the desirable limit without outside ventilation air (ASHRAE } \\
\text { Standard } 62-1989 \text { sets a minimum standard for air change rates and for tightly } \\
\text { sealed homes recommends mechanical ventilation to maintain } 0.35 \text { Air Changes } \\
\text { per Hour }(\mathrm{ACH}) \text {. HERS and IECC also require a minimum of } 0.35 \mathrm{ACH} \text {.) }\end{array}$ & 50 & 40 & 60 & 50 \\
\hline & Infiltration $(\mathrm{ACH})-$ & & & & \\
\hline & $\begin{array}{l}\text { Represents a combination of incandescent, compact fluorescent light (CFL), linear } \\
\text { fluorescent, and SSL }\end{array}$ & 0.35 & 0.4 & 0.35 & 0.35 \\
\hline & Average Lighting Efficacy $(\mathrm{lm} / \mathrm{W})$ & 60 & 50 & 120 & 90 \\
\hline & Plug Loads (\% change over baseline) - & & & & \\
\hline & $\begin{array}{l}\text { Increasing proliferation of electronic devices is expected to continue as devices } \\
\text { become more efficient, so efficiency impact somewhat offset. }\end{array}$ & $-10 \%$ & $-10 \%$ & $-20 \%$ & $-20 \%$ \\
\hline & Water Heating Water Load (\% change over baseline) - & & & & \\
\hline & $\begin{array}{l}\text { Flow reduction (e.g., low flow faucets), reduced runtime (e.g., passive infrared } \\
\text { activated faucets), insulating pipe runs (new buildings) }\end{array}$ & $-10 \%$ & $-5 \%$ & $-20 \%$ & $-10 \%$ \\
\hline \multirow{3}{*}{$\begin{array}{l}\text { Equipment } \\
\text { Performance: }\end{array}$} & Cool (SEER)--Heat Pump & 21 & 21 & 25 & 25 \\
\hline & Heat (HSPF)--Heat Pump & 10.8 & 10.8 & 13 & 13 \\
\hline & WH (EF)--Heat Pump & 2 & 2 & 3 & 3 \\
\hline
\end{tabular}




\subsubsection{Plug Loads}

A new BTP activity designed to eliminate stand-by losses of electric plug devices would be initiated to target some ${ }^{35}$ of the large portion of the Reference Case baseline attributed by EIA to "other" residential uses. PNNL assumes that a BTP program would target the saving of at least $75 \%$ of all standby power use in the most prolific electric devices, including TVs, microwaves, electric spas, home audio equipment, coffee makers, desktop PCs, laptops, set-top boxes, and computer monitors (see Table 4.1 for specific coverage of residential end uses). PNNL assumed a BT R\&D activity would result in a commercial technology and that standards-setting activities would advance the technology into the marketplace. Further, because the turnover of electric plug devices is rapid relative to other residential technologies such as HVAC equipment or windows, PNNL assumed that by 2020 the resulting technology would saturate market segments for all the devices listed.

\subsubsection{Solar Photovoltaic}

To ensure consistency with the solar photovoltaic (PV) goals of DOE's Solar America Initiative, PNNL adopted estimates of PV's potential, and market penetration assumptions, in residential and commercial buildings. Specifically, the PV estimate was taken from draft calculations prepared by Dr. Robert Margolis, NREL, to estimate the potential impacts of a combined zero-net energy buildings vision involving both aggressive end-use efficiency and rooftop PV systems. The targets for total installed capacity from this vision provide the basis of the PV estimates: 5-10 gigawatts (GW) of PV installed by 2015 and 70-100 GW of PV installed by 2030, for both residential and commercial buildings. The vision assumed a 50/50 split between residential and commercial buildings. PNNL used the PV generation estimates for the "high" scenario of commercial sector PV generation. The calculations underlying estimates are documented ${ }^{36}$ in a spreadsheet entitled "vision benefits estimate10-05-06.xls" and a narrative provided in short white paper, "Benefits of the Vision 10-05-06.doc," attached as Appendixes $\mathrm{C}$ and $\mathrm{D}$, respectively.

Specifically, the 2025 PV savings opportunity in commercial was calculated as follows (See Appendix C):

Given: Commercial floorspace available for $\mathrm{PV}=5$ billion $\mathrm{ft}^{2}$

Floorspace-to-roofspace factor $=1.7$

$\mathrm{PV}$ energy $=1705 \mathrm{kWh} /$ year per KW of PV

PV intensity $=100 \mathrm{ft}^{2}$ per KW of PV

Electricity to BTU conversion $=3412 \mathrm{Btu} / \mathrm{kWh}$

Site to source conversion factor $=3.22$

\footnotetext{
${ }^{35}$ EIA's "other" includes devices that fall outside "standby" considerations such as plug-in electric heaters, electric exercise equipment, etc. ${ }^{36}$ The draft analysis of the Solar America Initiative is intentionally high-level and coarse, of necessity, to provide a general magnitude of the expected energy benefits expected from wide adoption of PV technology. As such, no accounting is offered for assumed solar irradiance, climatic warming effects, or other factors. Market penetration rates assume continued technological development leading to increased PV efficiency at falling costs.
} 
Commercial PV Energy Savings $=[(5 \times 1.7 \times 1705 \times 3.22 \times 3412) /(1.7 \times 100 \times 1000)] / 1000=$ 0.937 Source $^{37}$ QBtu

The 2025 PV savings opportunity in residential was calculated as follows (from the attached spreadsheet):

Given: $\quad$ US households adopting rooftop PV $=12.5$ million

Avg residential system size $=4 \mathrm{KW}$

$\mathrm{PV}$ energy $=1705 \mathrm{kWh} /$ year per KW of PV

Electricity to BTU conversion $=3412 \mathrm{Btu} / \mathrm{kWh}$

Site to source conversion factor $=3.22$

Residential PV Energy Savings $=(4 \times 1705 \times 3.22 \times 3412 \times 12.5) / 10^{9}=0.937$ Source $^{38}$ QBtu

\footnotetext{
${ }^{37}$ The flow shows 0.29 QBtu, which is a "site" number for energy produced by an on-site technology. The source energy number shown is the primary energy that would have otherwise been provided by electricity produced using the expected average fuel mix, and is captured in Figure 12 's electric utility shadow.

${ }^{38}$ The flow shows 0.29 QBtu, which is a "site" number for energy produced by an on-site technology. The source energy number shown is the primary energy that would have otherwise been provided by electricity produced using the expected average fuel mix, and is captured in Figure 12 's electric utility shadow.
} 



\subsection{Discussion}

When considering the results of this analysis, the information portrayed in Figures 2.2 and 2.3 provides added context. Figure 2.2 illustrates EIA's forecast of new additions to commercial floorspace through 2030, and Figure 2.3 indicates similar information for the residential sector. While a greatly expanded buildings program could have significant impacts on new commercial floorspace in the future, the scope of that opportunity is limited when viewed across the existing building stock. Also, while roughly 30 million new single family units will be built by 2030, the existing stock of homes will hover around 80 million units over that time period, and as previously noted, existing homes are more difficult to penetrate. Of further note, the 2008 AEO Reference Case reflects the Extended Industry Standard Architecture (EISA) 2007 provision which would essentially result in the disappearance of incandescent lamps from the residential stock after 2012. This partially accounts for the rapidly decreasing energy intensity in the residential sector and is in some sense a measure of past BT success in helping to produce a market acceptable CFL lamp.

As illustrated in Table 6.1 and documented in Appendix A, EIA estimates that nearly one third of commercial sector primary energy consumption falls into the "other" classification, a hodgepodge of miscellaneous end uses such as telecommunications equipment, automated teller machines, and medical equipment, among many others. This category is also a catch-all for statistical adjustments between supply side and end-use survey EIA data sources. EIA projects this segment of the commercial sector to grow to greater than a one-third share of consumption over the analysis period. "Other" is nearly the fastest growing end use in commercial, and along with the EIA-projected growth in non-PC office equipment, causes the sector to grow much more rapidly as a whole. For example, according to EIA, space heating, space cooling, water heating, and lighting uses combined are expected to grow by 12 percent between 2009 and 2025, while non-PC office equipment and "other" uses combined are expected to grow 44.4 percent in the same period.

According to EIA and as shown in Figure 6.1, "Other" end uses represent the largest segment of building-sector consumption, and are forecast to increase their share. EIA has not adequately defined these "Other" uses, and as such developing technology-specific assumptions is not possible. Under the Lost Opportunities case, some sort of program response results in holding consumption growth to the rate of floorspace increase - essentially leveling growth in energy intensity for "Other". It is plausible (and assumed) that BTP measures could be expected to decrease consumption from the 2009 baseline and that this will likely be accomplished by some combination of research into appliance research, standards, and perhaps a labeling program like Energy Star. 
Table 6.1. Comparison of Forecasted AEO 2008 Reference Case Commercial Sector End Use Consumption

\begin{tabular}{|c|c|c|c|c|c|c|c|}
\hline $\begin{array}{l}\text { Commercial } \\
\text { Sector End Use }\end{array}$ & $\begin{array}{c}2009 \\
\text { Commercial } \\
\text { Primary } \\
\text { Consumption } \\
\text { (QBtu) }\end{array}$ & $\begin{array}{c}\text { Share of } \\
\text { Consumption }\end{array}$ & $\begin{array}{c}2025 \\
\text { Commercial } \\
\text { Primary } \\
\text { Consumption } \\
\text { (QBtu) }\end{array}$ & $\begin{array}{c}\text { Share of } \\
\text { Consumption }\end{array}$ & $\begin{array}{c}\text { Change in } \\
\text { Primary } \\
\text { Consumption } \\
\text { (QBtu) }\end{array}$ & $\begin{array}{c}\text { Share of } \\
\text { Change in } \\
\text { Consumption }\end{array}$ & $\begin{array}{l}\text { Percentage } \\
\text { Change in } \\
\text { Consumption } \\
(2009-2025)\end{array}$ \\
\hline Space Heating & 1.88 & $10.13 \%$ & 2.02 & $8.56 \%$ & 0.13 & $2.70 \%$ & $7.10 \%$ \\
\hline Space Cooling & 1.57 & $8.47 \%$ & 1.81 & $7.67 \%$ & 0.23 & $4.66 \%$ & $14.69 \%$ \\
\hline Water Heating & 1.07 & $5.75 \%$ & 1.25 & $5.29 \%$ & 0.18 & $3.55 \%$ & $16.48 \%$ \\
\hline Ventilation & 0.60 & $3.21 \%$ & 0.68 & $2.88 \%$ & 0.08 & $1.66 \%$ & $13.83 \%$ \\
\hline Cooking & 0.36 & $1.94 \%$ & 0.42 & $1.80 \%$ & 0.06 & $1.25 \%$ & $17.15 \%$ \\
\hline Lighting & 3.55 & $19.09 \%$ & 3.96 & $16.83 \%$ & 0.42 & $8.37 \%$ & $11.71 \%$ \\
\hline Refrigeration & 0.73 & $3.95 \%$ & 0.82 & $3.49 \%$ & 0.09 & $1.73 \%$ & $11.69 \%$ \\
\hline $\begin{array}{l}\text { Office } \\
\text { Equipment } \\
\text { (PC) }\end{array}$ & 0.81 & $4.34 \%$ & 1.02 & $4.35 \%$ & 0.22 & $4.35 \%$ & $26.72 \%$ \\
\hline $\begin{array}{l}\text { Office } \\
\text { Equipment } \\
\text { (non-PC) }\end{array}$ & 1.65 & $8.88 \%$ & 2.68 & $11.39 \%$ & 1.03 & $20.80 \%$ & $62.48 \%$ \\
\hline Other Uses* & 6.36 & $34.24 \%$ & 8.89 & $37.75 \%$ & 2.53 & $50.93 \%$ & $39.69 \%$ \\
\hline Totals & 18.58 & $100.00 \%$ & 23.54 & $100.00 \%$ & 4.96 & $100.00 \%$ & $26.68 \%$ \\
\hline
\end{tabular}

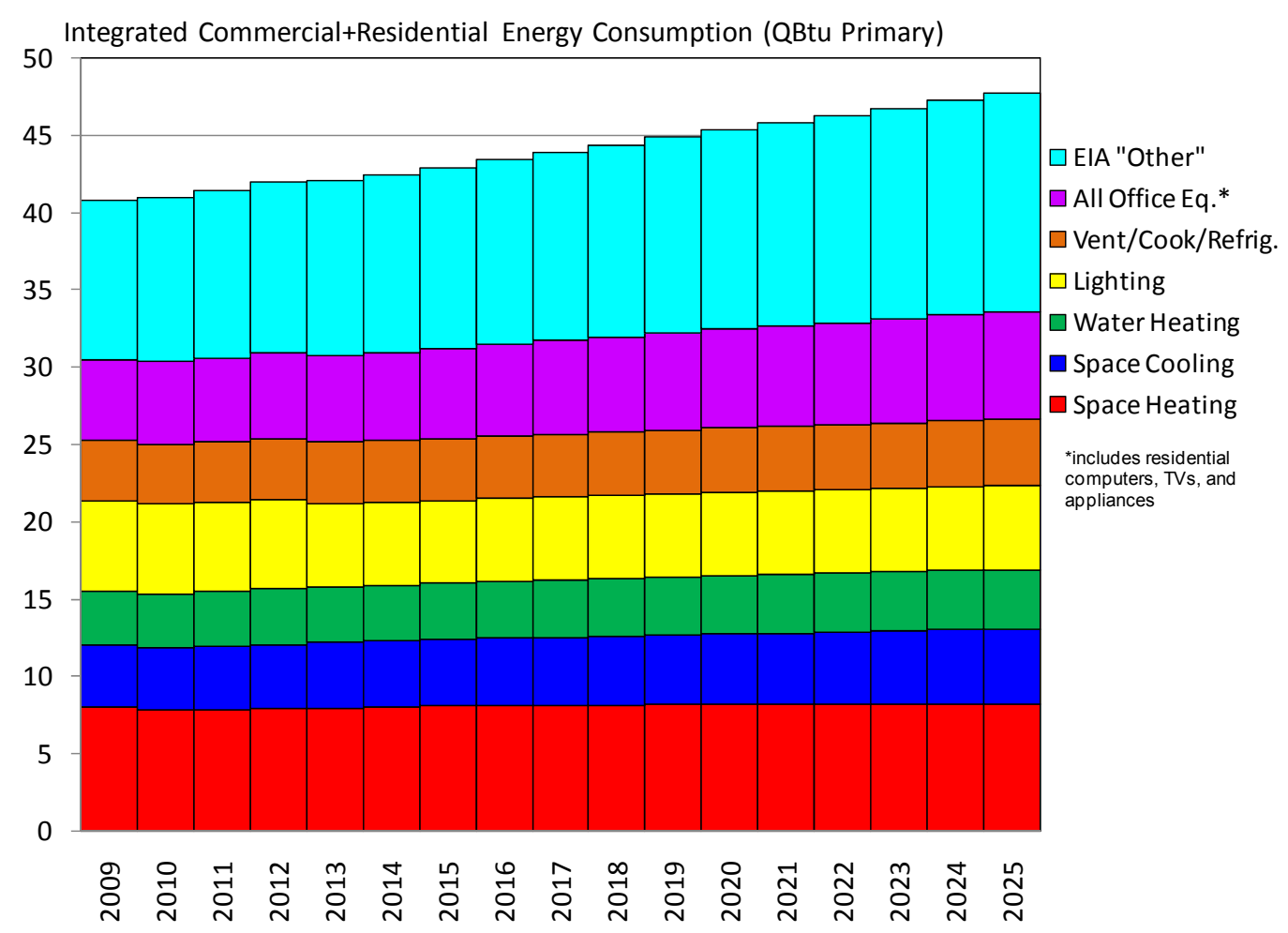

Figure 6.1. AEO 2008 Reference Case Projection for the Combined Commercial and Residential Sectors, Broken Out by the End Uses Considered in This Analysis 
Being cognizant of the extraordinary magnitude of "other" and of the projections for its growth by EIA, BTP commissioned PNNL to look at "other" electricity use issues in some detail in June 2007. The results of that investigation are documented in a technical memo and contained in Appendix A. In essence, PNNL found that EIA's documentation of "Other Uses" as footnoted in the AEO does not make clear that this entry includes miscellaneous electricity within buildings, non-building use, and a statistical discrepancy between EIA data sources. ${ }^{39}$ Further, little to no documentation of the underlying penetration rates of the miscellaneous electricity uses within buildings has been provided by EIA. However, the official EIA "other use" projections are accepted as they are and this analysis endeavors to address them as best possible.

Trends affecting the residential sector are shown in Table 6.2. According to AEO 2008, the average annual growth in residential primary energy consumption, from 2006 through 2030 is $0.5 \%$ for water heating, $0.8 \%$ for space heating, $1.4 \%$ for space cooling, $-1.7 \%$ for lighting, $2.1 \%$ for other uses, $3.6 \%$ for personal computers, and $2.2 \%$ for color televisions and set-top boxes. The fact that residential lighting energy use is forecast to decline significantly over time appears to suggest the effects of EISA 2007 taking effect in the market with the elimination of the incandescent lamp. However, nearly $2 / 3$ of the expected increase in residential energy consumption between 2009 and 2025 comes from "other" or "miscellaneous" energy uses not further classified by EIA — echoing the issue illustrated in the commercial sector.

Table 6.2. Comparison of Forecasted AEO 2008 Reference Case Residential Sector End Use Consumption

\begin{tabular}{|c|c|c|c|c|c|c|c|}
\hline $\begin{array}{c}\text { Residential Sector End } \\
\text { Use }\end{array}$ & $\begin{array}{c}2009 \\
\text { Residential } \\
\text { Primary } \\
\text { Consumption } \\
\text { (QBtu) }\end{array}$ & $\begin{array}{c}\text { Share of } \\
\text { Consumption }\end{array}$ & $\begin{array}{c}2025 \\
\text { Residential } \\
\text { Primary } \\
\text { Consumption } \\
\text { (QBtu) }\end{array}$ & $\begin{array}{c}\text { Share of } \\
\text { Consumption }\end{array}$ & $\begin{array}{l}\text { Change in } \\
\text { Primary } \\
\text { Consumption } \\
\text { (QBtu) }\end{array}$ & $\begin{array}{c}\text { Share of } \\
\text { Change in } \\
\text { Consumption }\end{array}$ & $\begin{array}{l}\text { Percentage } \\
\text { Change in } \\
\text { Consumption } \\
(2009-2025)\end{array}$ \\
\hline Space Heating & 6.133 & $27.62 \%$ & 6.217 & $25.74 \%$ & 0.084 & $4.30 \%$ & $1.36 \%$ \\
\hline Space Cooling & 2.461 & $11.08 \%$ & 3.012 & $12.47 \%$ & 0.550 & $28.30 \%$ & $22.36 \%$ \\
\hline Water Heating & 2.429 & $10.94 \%$ & 2.590 & $10.72 \%$ & 0.161 & $8.28 \%$ & $6.63 \%$ \\
\hline Refrigeration & 1.169 & $5.26 \%$ & 1.164 & $4.82 \%$ & -0.005 & $-0.25 \%$ & $-0.42 \%$ \\
\hline Cooking & 0.591 & $2.66 \%$ & 0.697 & $2.89 \%$ & 0.106 & $5.48 \%$ & $18.02 \%$ \\
\hline Clothes Dryers & 0.871 & $3.92 \%$ & 0.949 & $3.93 \%$ & 0.078 & $3.99 \%$ & $8.91 \%$ \\
\hline Freezers & 0.254 & $1.15 \%$ & 0.311 & $1.29 \%$ & 0.057 & $2.93 \%$ & $22.37 \%$ \\
\hline Lighting & 2.275 & $10.24 \%$ & 1.469 & $6.08 \%$ & -0.806 & $-41.45 \%$ & $-35.44 \%$ \\
\hline Clothes Washers & 0.105 & $0.47 \%$ & 0.081 & $0.34 \%$ & -0.024 & $-1.23 \%$ & $-22.78 \%$ \\
\hline Dishwashers & 0.292 & $1.32 \%$ & 0.311 & $1.29 \%$ & 0.018 & $0.95 \%$ & $6.29 \%$ \\
\hline $\begin{array}{l}\text { Color Televisions and } \\
\text { Set-Top Boxes }\end{array}$ & 1.205 & $5.43 \%$ & 1.494 & $6.19 \%$ & 0.289 & $14.88 \%$ & $24.01 \%$ \\
\hline Personal Computers & 0.277 & $1.25 \%$ & 0.427 & $1.77 \%$ & 0.150 & $7.73 \%$ & $54.30 \%$ \\
\hline Furnace Fans & 0.202 & $0.91 \%$ & 0.236 & $0.98 \%$ & 0.034 & $1.76 \%$ & $16.93 \%$ \\
\hline Other Uses * & 3.942 & $17.75 \%$ & 5.193 & $21.50 \%$ & 1.251 & $64.35 \%$ & $31.75 \%$ \\
\hline Total & 22.208 & $100.00 \%$ & 24.152 & $100.00 \%$ & 1.945 & $100.00 \%$ & $8.76 \%$ \\
\hline
\end{tabular}

\footnotetext{
${ }^{39}$ For more on the difference between these data sources, please see DB Belzer, Estimates of U.S. Commercial Building Electricity Intensity Trends: Issues Related to End-Use and Supply Surveys. September 2007, PNNL-16820, Pacific Northwest National Laboratory, Richland, WA. http://www.pnl.gov/main/publications/external/technical_reports/PNNL-16820.pdf
} 
The delivered energy savings results are presented in Table 6.3 for commercial and Table 6.4 for residential by end use, building type, and fuel type, in site QBtu. Delivered electricity savings in 2025 amount to about $70.9 \%$ of site energy savings in commercial buildings and $48.6 \%$ in residential buildings under the Lost Opportunities case. The principal end uses affected by BTP's research activities provide an estimated $49.5 \%$ of the combined commercial and residential end use savings under then Lost Opportunities case in 2025. "Other" end uses account for about $19.6 \%$ of the estimated site energy savings under the same case.

Table 6.3. Lost Opportunities Case Energy Savings by Commercial End Use and Vintage, Site QBtu in 2025

\begin{tabular}{|c|c|c|c|c|c|c|c|c|c|}
\hline End Use & $\begin{array}{l}\text { Elec - } \\
\text { New }\end{array}$ & $\begin{array}{l}\text { Gas - } \\
\text { New }\end{array}$ & $\begin{array}{l}\text { Oil - } \\
\text { New }\end{array}$ & $\begin{array}{c}\text { Other - } \\
\text { New }\end{array}$ & $\begin{array}{l}\text { Elec- } \\
\text { Exist }\end{array}$ & $\begin{array}{l}\text { Gas - } \\
\text { Exist }\end{array}$ & $\begin{array}{l}\text { Oil - } \\
\text { Exist }\end{array}$ & $\begin{array}{c}\text { Other - } \\
\text { Exist }\end{array}$ & $\begin{array}{l}\text { Total } \\
\text { End } \\
\text { Use }\end{array}$ \\
\hline Space Heating & 0.010 & 0.105 & 0.014 & 0.000 & 0.017 & 0.113 & 0.019 & 0.000 & 0.277 \\
\hline Space Cooling & 0.034 & 0.002 & 0.000 & 0.000 & 0.064 & 0.003 & 0.000 & 0.000 & 0.102 \\
\hline Water Heating & 0.012 & 0.019 & 0.004 & 0.000 & 0.015 & 0.019 & 0.007 & 0.000 & 0.075 \\
\hline Ventilation & 0.000 & 0.000 & 0.000 & 0.000 & 0.000 & 0.000 & 0.000 & 0.000 & 0.000 \\
\hline Cooking & 0.000 & 0.000 & 0.000 & 0.000 & 0.000 & 0.000 & 0.000 & 0.000 & 0.000 \\
\hline Lighting & 0.109 & 0.000 & 0.000 & 0.000 & 0.103 & 0.000 & 0.000 & 0.000 & 0.212 \\
\hline Refrigeration & 0.028 & 0.000 & 0.000 & 0.000 & 0.065 & 0.000 & 0.000 & 0.000 & 0.093 \\
\hline Office Equipment (PC) & 0.021 & 0.000 & 0.000 & 0.000 & 0.050 & 0.000 & 0.000 & 0.000 & 0.071 \\
\hline Office Equipment (non-PC) & 0.065 & 0.000 & 0.000 & 0.000 & 0.152 & 0.000 & 0.000 & 0.000 & 0.217 \\
\hline Other Uses & 0.086 & 0.045 & 0.008 & 0.018 & 0.202 & 0.106 & 0.019 & 0.043 & 0.529 \\
\hline Total & 0.365 & 0.171 & 0.027 & 0.018 & 0.667 & 0.241 & 0.045 & 0.043 & 1.576 \\
\hline
\end{tabular}

Table 6.4. Lost Opportunities Case Energy Savings by Residential End Use and Stock Vintage, Site QBtu in 2025

\begin{tabular}{|c|c|c|c|c|c|c|c|c|c|}
\hline End Use & $\begin{array}{l}\text { Elec- } \\
\text { New }\end{array}$ & $\begin{array}{l}\text { Gas - } \\
\text { New }\end{array}$ & $\begin{array}{l}\text { Oil - } \\
\text { New }\end{array}$ & $\begin{array}{l}\text { Other - } \\
\text { New }\end{array}$ & $\begin{array}{l}\text { Elec - } \\
\text { Exist }\end{array}$ & $\begin{array}{l}\text { Gas - } \\
\text { Exist }\end{array}$ & $\begin{array}{l}\text { Oil - } \\
\text { Exist }\end{array}$ & $\begin{array}{c}\text { Other - } \\
\text { Exist }\end{array}$ & $\begin{array}{l}\text { Total } \\
\text { End } \\
\text { Use }\end{array}$ \\
\hline Space Heating & 0.008 & 0.144 & 0.007 & 0.013 & 0.051 & 0.621 & 0.117 & 0.127 & 1.088 \\
\hline Space Cooling & 0.028 & 0.000 & 0.000 & 0.000 & 0.066 & 0.000 & 0.000 & 0.000 & 0.095 \\
\hline Water Heating & 0.021 & 0.042 & 0.001 & 0.000 & 0.013 & 0.037 & 0.003 & 0.002 & 0.120 \\
\hline Refrigeration & 0.013 & 0.000 & 0.000 & 0.000 & 0.048 & 0.000 & 0.000 & 0.000 & 0.061 \\
\hline Cooking & 0.005 & 0.010 & 0.000 & 0.001 & 0.018 & 0.036 & 0.000 & 0.005 & 0.075 \\
\hline Clothes Dryers & 0.010 & 0.003 & 0.000 & 0.000 & 0.036 & 0.011 & 0.000 & 0.000 & 0.060 \\
\hline Freezers & 0.004 & 0.000 & 0.000 & 0.000 & 0.013 & 0.000 & 0.000 & 0.000 & 0.016 \\
\hline Lighting & 0.067 & 0.000 & 0.000 & 0.000 & 0.060 & 0.000 & 0.000 & 0.000 & 0.127 \\
\hline Clothes Washers & 0.001 & 0.000 & 0.000 & 0.000 & 0.003 & 0.000 & 0.000 & 0.000 & 0.004 \\
\hline Dishwashers & 0.004 & 0.000 & 0.000 & 0.000 & 0.013 & 0.000 & 0.000 & 0.000 & 0.016 \\
\hline $\begin{array}{l}\text { Color Televisions and Set-Top } \\
\text { Boxes }\end{array}$ & 0.017 & 0.000 & 0.000 & 0.000 & 0.061 & 0.000 & 0.000 & 0.000 & 0.078 \\
\hline Personal Computers & 0.005 & 0.000 & 0.000 & 0.000 & 0.018 & 0.000 & 0.000 & 0.000 & 0.022 \\
\hline Furnace Fans & 0.003 & 0.000 & 0.000 & 0.000 & 0.010 & 0.000 & 0.000 & 0.000 & 0.012 \\
\hline Other Uses & 0.057 & 0.000 & 0.000 & 0.008 & 0.206 & 0.000 & 0.000 & 0.029 & 0.300 \\
\hline Total & 0.242 & 0.199 & 0.008 & 0.023 & 0.616 & 0.705 & 0.120 & 0.162 & 2.075 \\
\hline
\end{tabular}


Figure 6.2 through 6.7 provide results further broken down by vintage and end use. The BT BAU case and the Lost Opportunities case are compared to the AEO Reference Case. These figures illustrate the dramatic difference in the opportunity BT has in the existing stock versus the new stock over the 2009-2025 period. Over 12 QBtu (primary) of total new consumption is forecast to come online between 2008 and 2025 in the buildings sector, while an annual 40 QBtu decreasing to 35 QBtu (primary) of opportunity persists in the existing stock. That is, new buildings sector primary energy consumption grows from 0 QBtu in 2008 to over 12 QBtu per year by 2025; existing primary energy consumption starts at 40 QBtu per year in 2008 and only falls to 35 QBtu per year by 2025 . New consumption is only one-third of 2008 existing stock's consumption by 2025; it is much less than this for most of the 17-year period.

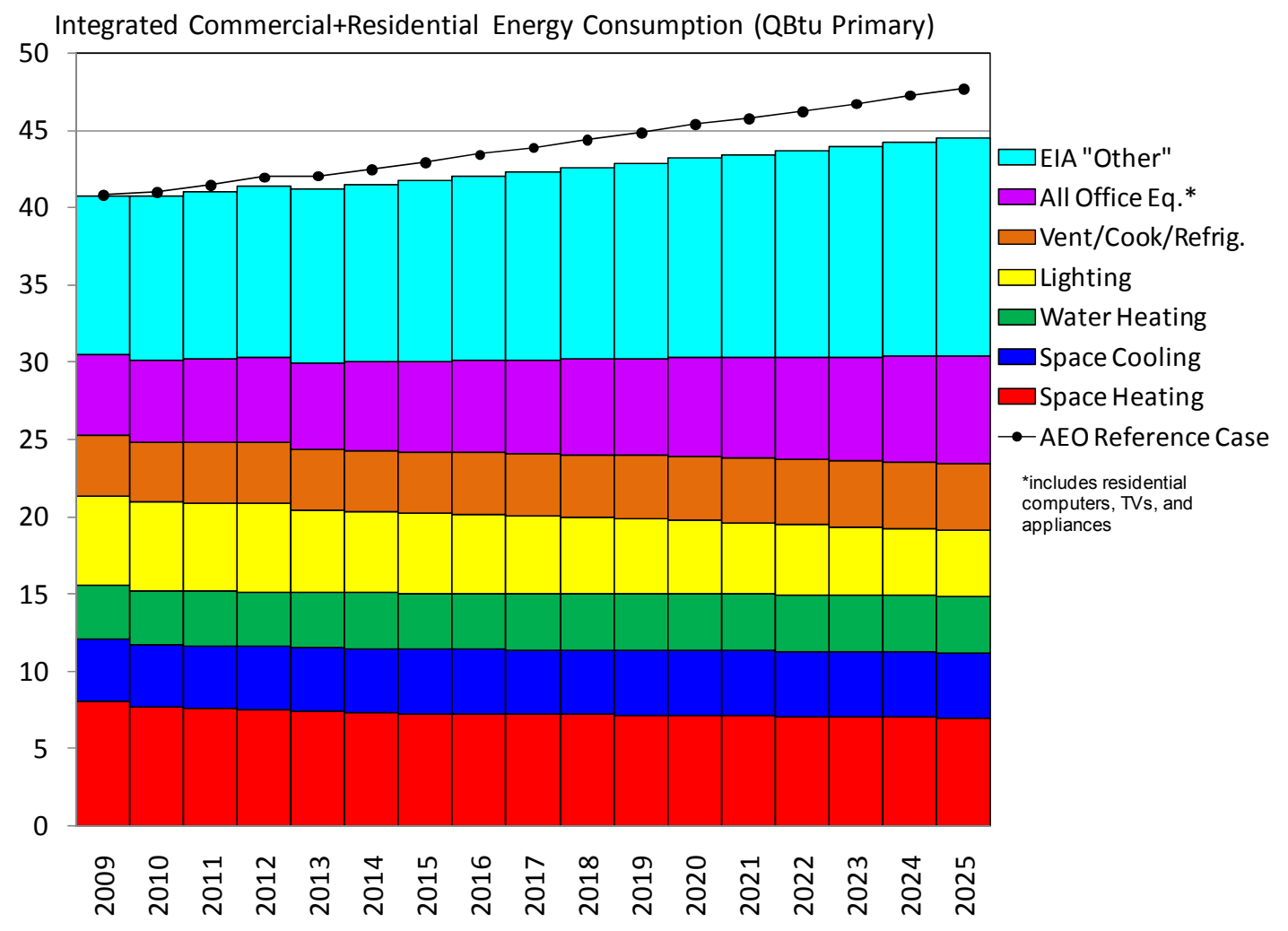

Figure 6.2. Integrated (Non-overlapping) Commercial and Residential End Uses Represented in the BT BAU Case 


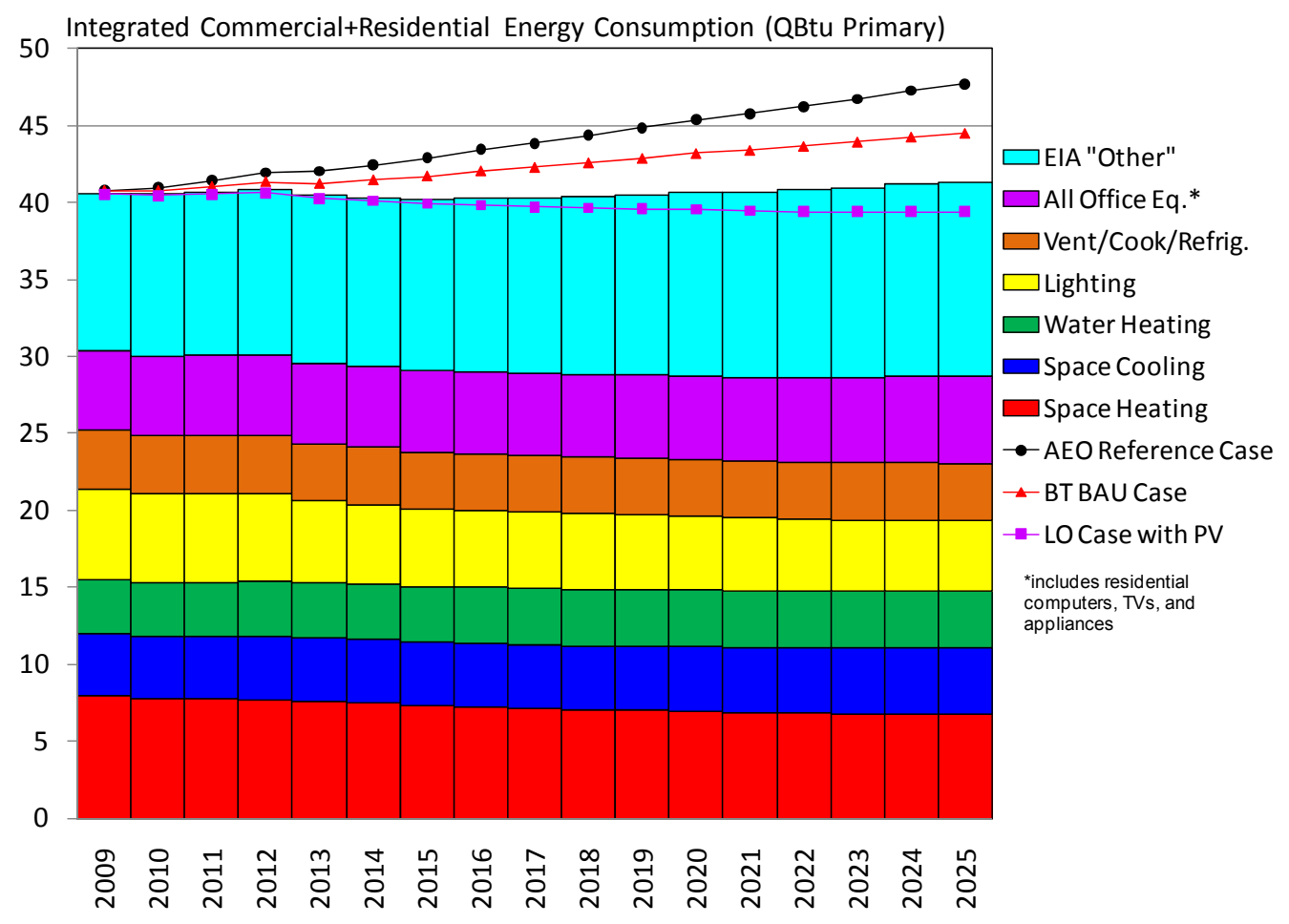

Figure 6.3. Integrated (Non-overlapping) Commercial and Residential End Uses Represented in the BT Lost Opportunities Case

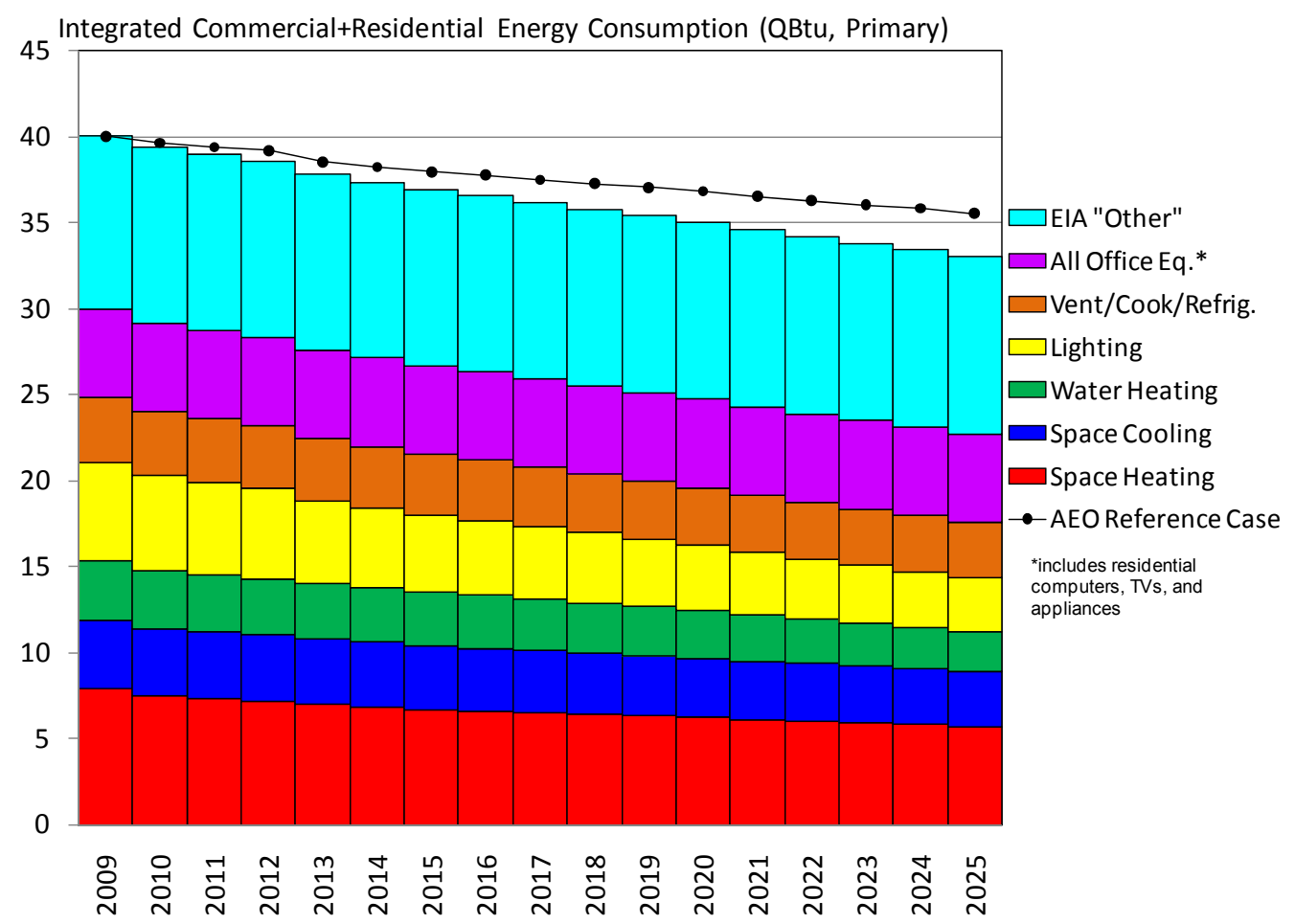

Figure 6.4. Integrated (Non-overlapping) Commercial and Residential End Uses Represented in the BT BAU Case (Existing Stock) 


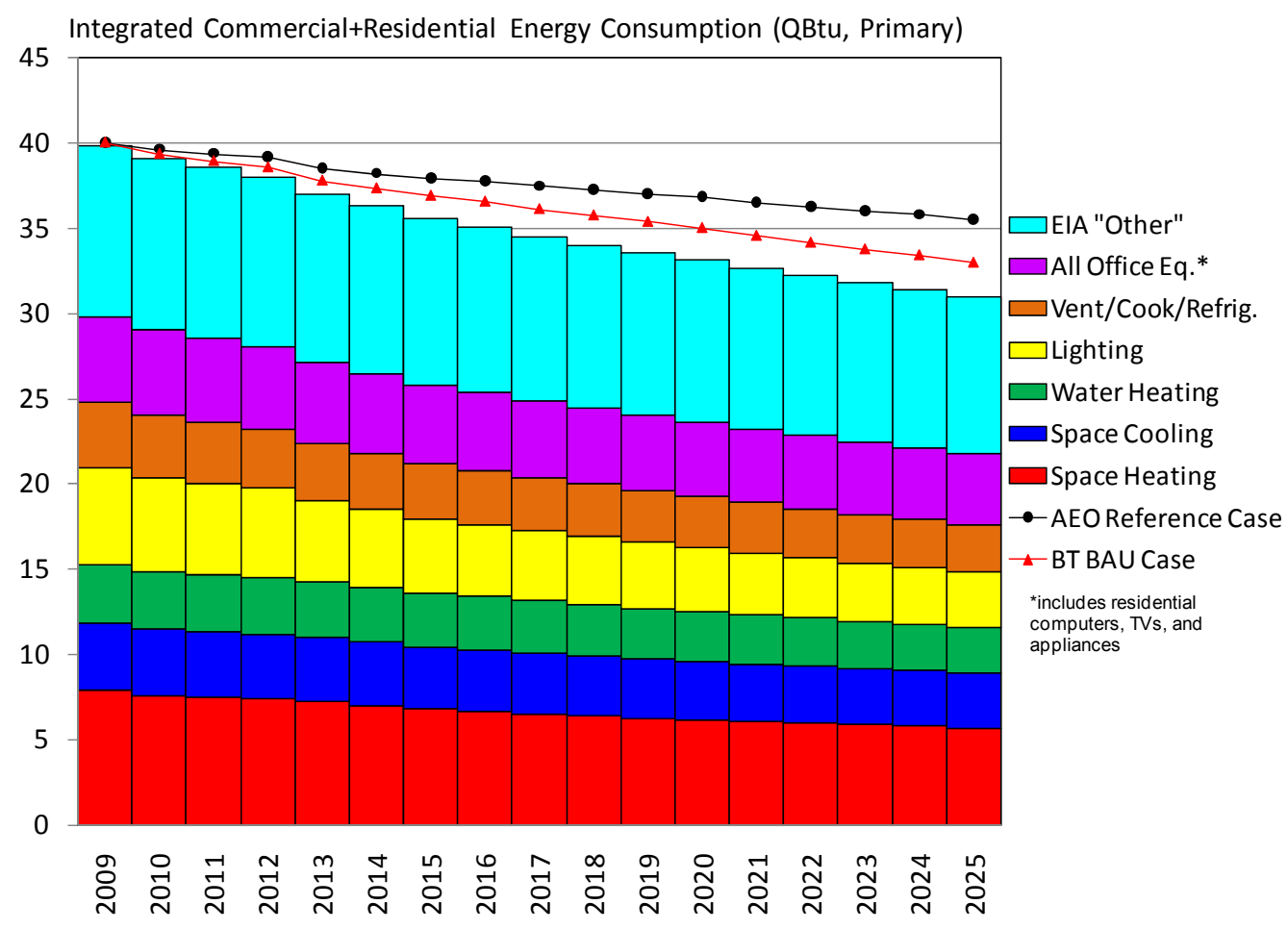

Figure 6.5. Integrated (Non-overlapping) Commercial and Residential End Uses Represented in the BT Lost Opportunities Case (Existing Stock)

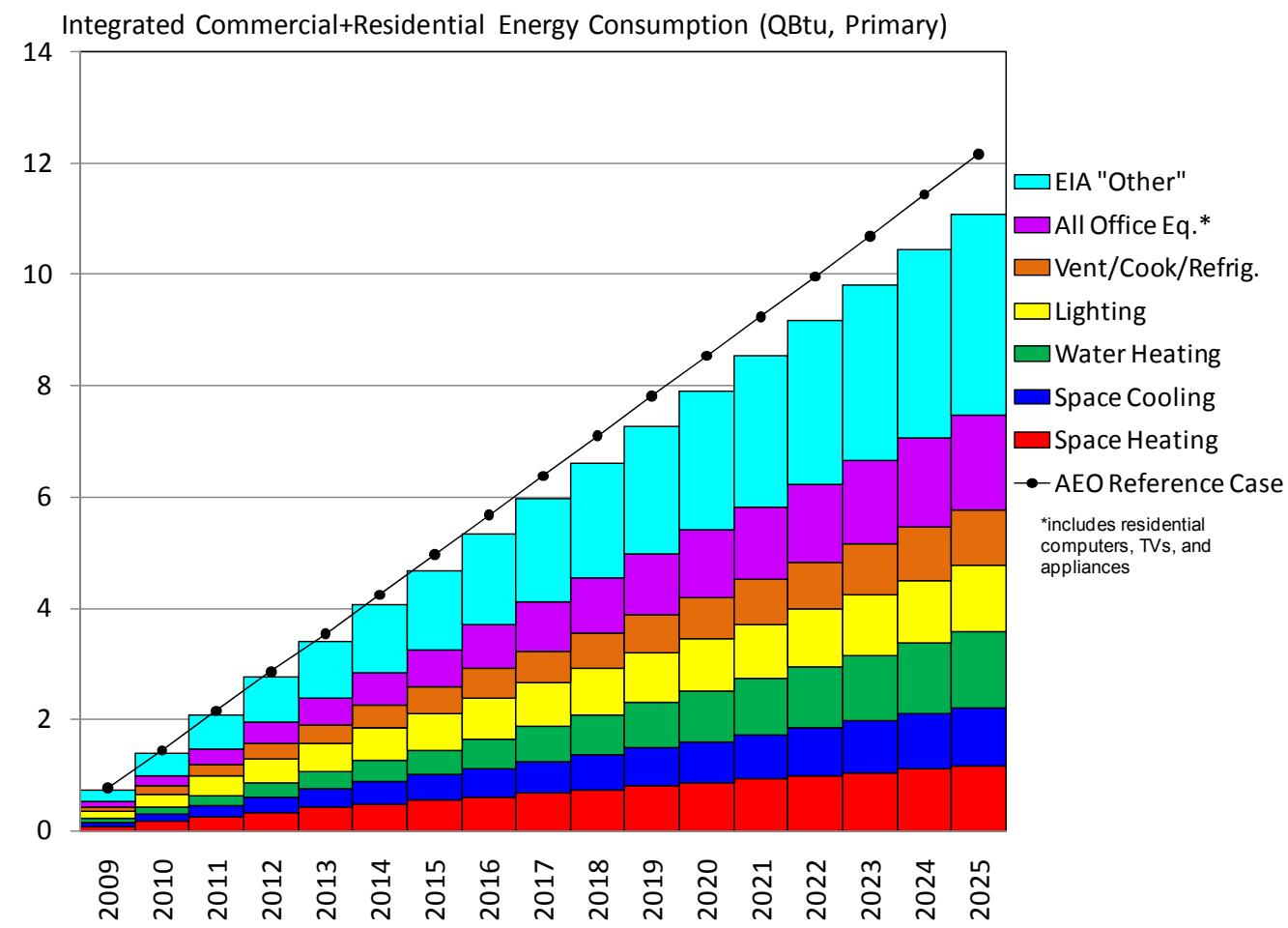

Figure 6.6. Integrated (Non-overlapping) Commercial and Residential End Uses Represented in the BT BAU Case (New Stock Additions) 


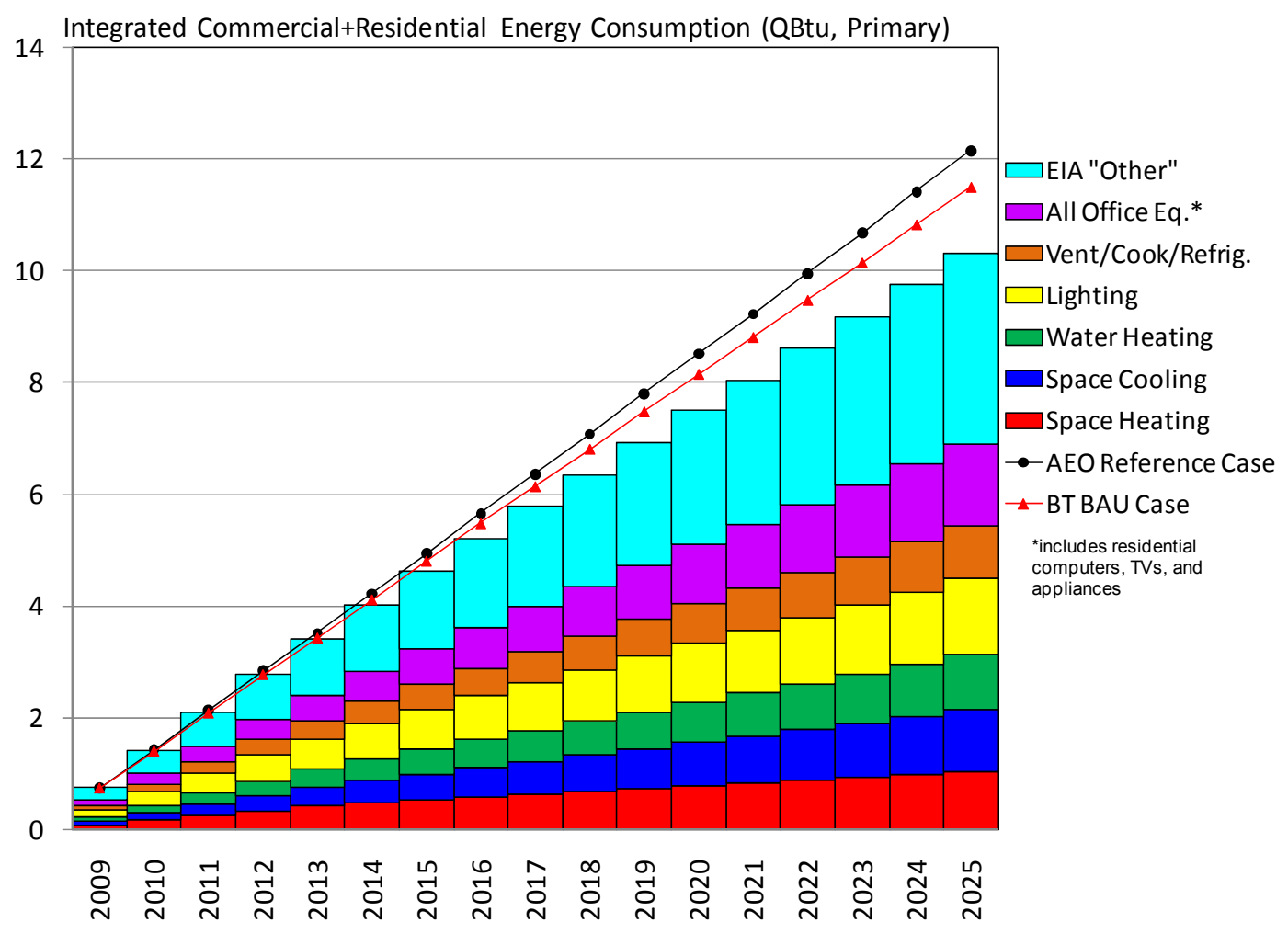

Figure 6.7. Integrated (Non-overlapping) Commercial and Residential End Uses Represented in the BT Lost Opportunities Case (New Stock Additions) 


\subsection{Avoided $\mathrm{CO}_{2}$ Emissions}

The importance of reductions in $\mathrm{CO}_{2}$ emissions as a performance metric (program benefit) has increased significantly. The modeling of $\mathrm{CO}_{2}$ emissions has also evolved from simple coefficients associated with energy forms to more complex calculations. Estimating marginal $\mathrm{CO}_{2}$ savings based on $\mathrm{CO}_{2}$ emissions per unit of energy consumption is a typical method of calculating $\mathrm{CO}_{2}$ reductions. Previously, in the analysis of the commercial buildings sector ${ }^{40}$ yearly marginal $\mathrm{CO}_{2}$ emission factors were determined by taking the difference between the AEO base case consumption and emissions and those of the low economic growth case ${ }^{41}$. However, we discovered this approach can produce wild gyrations in carbon impacts due to changes in dispatch, retirements, and capacity additions in the AEO projections. These fluctuations are an artifact of this type of approach. In the analytical approach used in this paper, additions to generating capacity were considered at the margin as it is these plants that are going to be added to the national generation mix over the 2009 to 2025 timeframe. It was further surmised that an average across these plants may not fairly represent the $\mathrm{CO}_{2}$ savings associated with individual activities.

Similar to primary energy savings, $\mathrm{CO}_{2}$ savings must be calculated on a marginal basis; that is, it is not the average $\mathrm{CO}_{2}$ per unit of electricity production that is important, rather it is the amount of $\mathrm{CO}_{2}$ that would be avoided by reducing a unit of electricity production. To make this determination one must consider how a change in projected electricity demand would impact the electric generation capacity additions and retirements. Be it carbon or energy, those marginal changes are subtracted from the reference case to determine the emission level or consumption.

We derived a marginal $\mathrm{CO}_{2}$ value (Million Metric Tons/TBtu) from the planned capacity additions (AEO 2008, Table 6.3) and the projected heat rates and fuels types of the plants being added. These planned capacity additions are in response to projections of increased electricity demand. Because this increase in electricity demand is not constant (i.e., it varies seasonally and diurnally), different types of power plants will be constructed to meet the demand. Power plants with relatively high capital costs and relatively low operating costs (fuel and O\&M) are generally used as baseload plants because they offer the lowest cost baseload power (e.g., coal and nuclear). Conversely, power plants with relatively low capital costs and relatively high operating costs are generally used as peaking plants because they offer the lowest cost peaking power (e.g, natural gas combustion turbines). Operating characteristics of some technologies also impact their ability to be used as peaking or baseload plants; for example, combustion turbines can be brought from cold to full output in minutes while in a nuclear plant the same process takes days. Hence, specific heat rates were developed for peaking plants (combustion turbines), intermediate load plants (a combination a combined cycle gas plants and intermediate load coal plants), and baseload plants (a combination of coal and nuclear). Values were explicitly calculated for each year of the analysis and are reflected in Table 7.1.

\footnotetext{
${ }^{40}$ J.A. Dirks, D.M. Anderson, D.J. Hostick, D.B. Belzer, K.A. Cort, Oct. 2007, Lost Opportunities in the Commercial Sector: Draft Analysis and Results, PNNL-SA-57697.

${ }^{41}$ As part of the AEO, in addition to the Reference Case, EIA provides a handful of alternative data tables based on differing assumptions. It would be desirable to have a High Technology case; however the Integrated High Technology case is confounded with a number of additional assumptions which make it non-representative of the opportunities available to the buildings sector. Hence, PNNL deemed that the Low Economic Growth Case with its low growth in electricity demand and no explicit assumption changes for the base case regarding energy prices and technology cost would be most representative of question posed in this analysis.
} 
Table 7.1. Carbon Dioxide Emissions Factors (GigaTonnes CO2/QBtu - Site)

\begin{tabular}{lccc}
\hline \multicolumn{1}{c}{ Fuel } & 2009 & 2015 & 2025 \\
\hline Electricity (peaking marginal) & 0.1663 & 0.1626 & 0.1626 \\
Electricity (intermediate marginal) & 0.1442 & 0.1402 & 0.1402 \\
Electricity (baseload marginal) & 0.1836 & 0.1802 & 0.1802 \\
Electricity (combined marginal) & 0.1630 & 0.1587 & 0.1587 \\
Electricity PV (marginal) & 0.1552 & 0.1514 & 0.1514 \\
Electricity (average) & 0.1811 & 0.1781 & 0.1778 \\
Natural Gas & 0.0531 & 0.0531 & 0.0531 \\
Oil & 0.0732 & 0.0732 & 0.0732 \\
Other (Commercial Marginal) & 0.0527 & 0.0532 & 0.0534 \\
Other (Residential Marginal) & 0.0350 & 0.0368 & 0.0386 \\
\hline
\end{tabular}

The implications for $\mathrm{CO}_{2}$ emissions are rather profound. Peaking plants are relatively inefficient but use a relatively low $\mathrm{CO}_{2}$ emissions fuel (natural gas); the combined effect is that the $\mathrm{CO}_{2}$ emissions per $\mathrm{kWh}$ are comparatively moderate. Intermediate load plants are represented primarily by combined cycle gas plants which have the advantage of using a relatively low $\mathrm{CO}_{2}$ emissions fuel (natural gas) and have high efficiency, resulting in the lowest $\mathrm{CO}_{2}$ emissions per $\mathrm{kWh}$. Lastly, baseload plants are a combination of zero $\mathrm{CO}_{2}$ emission nuclear and baseload coal fired plants. Because the plans assume that the plants will be predominately baseload coal plants (relatively high efficiency and a very high $\mathrm{CO}_{2}$ emissions fuel) baseload plants have the highest $\mathrm{CO}_{2}$ emissions per $\mathrm{kWh}$; however, should those plans change to favor nuclear then baseload plants could have the lowest $\mathrm{CO}_{2}$ emissions per $\mathrm{kWh}$.

Because this is an integrated analysis, and the impact of the lost opportunities effort and BAU effort are cross-cutting, it can be reasonably assumed that the load reductions would be similar to the planned capacity additions in terms of the split between peak, intermediate, and baseload. Hence, for this analysis, the combined (national scale) marginal heat rate and $\mathrm{CO}_{2}$ coefficients were used. For example, the 2008 marginal heat rates $\left(\mathrm{Btu} / \mathrm{kwh}_{\mathrm{e}}\right)$ for peaking $(100 \%$ combustion turbines), intermediate $(73.3 \%$ combined cycle gas and $26.7 \%$ intermediate load coal), and baseload (76.8\% baseload coal and $23.2 \%$ nuclear) plants were 10,727, 7537, and 9205 respectively. These heat rates were then combined using the expected growth in each category as follows to determine the national scale marginal heat rate:

$(2.1 \% \times 10,727)+(18.4 \% \times 7,537)+(79.5 \% \times 9,163)=8,897 \mathrm{Btu} / \mathrm{kWh}$

Similarly, the $\mathrm{CO}_{2}$ emissions factor for electricity can be calculated using the mix of generating assets and knowing that the pounds of $\mathrm{CO}_{2}$ per MBtu of gas, coal (bituminous assumed), and nuclear fuel is 117.1, 205.3, and 0.0 respectively. Thus the national scale marginal $\mathrm{CO}_{2}$ coefficient is:

$(2.1 \% \times 1.256)+(18.4 \% \times 1.090)+(79.5 \% \times 1.385)=1.329 \mathrm{lb} \mathrm{CO}_{2} / \mathrm{kWh}$

If, however, one were looking at an individual technology such as cooling, it would be better to estimate heat rates and $\mathrm{CO}_{2}$ coefficients closer to the peaking and intermediate value, which would be more characteristic of when most of the load occurs.

The energy savings translate into potentially avoided $\mathrm{CO}_{2}$ emissions. Table 7.2 provides a summary of these impacts. Under the Lost Opportunities case, BTP's activities would result in the avoidance of more than $10.4 \%$ of the forecasted cumulative $\mathrm{CO}_{2}$ emissions in the buildings sector by 2025 . This represents $35.7 \%$ of the buildings sector technical potential in that period. 
Table 7.2. Annual Carbon Dioxide-Equivalent Emissions Impacts (GtCO2)

\begin{tabular}{lcccc}
\hline \multicolumn{1}{c}{ Analysis Case } & & & $\begin{array}{c}\text { Cumulative } \\
2009-2025\end{array}$ \\
\hline Total Buildings Sector Emissions $\left(\mathrm{GtCO}_{2}\right)$ & & & & \\
Reference Case & 2.30 & 2.42 & 2.70 & 42.14 \\
Lost Opportunities Case & 2.28 & 2.23 & 2.19 & 37.76 \\
Business as Usual Case & 2.30 & 2.35 & 2.50 & 40.46 \\
Technical Potential & 2.20 & 1.68 & 1.61 & 29.87 \\
Avoided Emissions $\left(\mathrm{GtCO}_{2}\right)$ & & & & \\
Lost Opportunities Case & 0.0149 & 0.1903 & 0.5117 & 4.38 \\
Business as Usual Case & 0.0005 & 0.0697 & 0.2031 & 1.68 \\
Technical Potential & 0.1041 & 0.7395 & 1.0886 & 12.26 \\
\hline
\end{tabular}





\subsection{Energy Flow Maps}

Taken together, Figures 8.1 and 8.2 represent the potential energy savings from the Lost Opportunities case in terms of the principal energy flows that can be associated with the buildings sector. Figure 8.1 projects the 2025 energy flows implied by the Reference case of the 2008 Annual Energy Outlook. Shown on the top left of the figure are the flows of fossil fuels used by the electric power sector to meet the projected electricity demand. Coal dominates this picture. The large flow on the top right portion of the figure shows the generation and transmission losses associated with the electricity used by the buildings sector.

Below the fossil fuels are shown the amounts of electricity production from non-fossil sources: nuclear, hydroelectric, and biomass. The treatment of non-fossil electricity generation differs from the EIA convention of imputing generation losses to each of these fuels - in the figure only the Btu content of the electricity generated is shown ${ }^{1}$. The bottom set of arrows in the figure shows the direct consumption of fossil fuels by households, with natural gas as the dominant fuel.

The right side of Figure 8.1 shows the projected distribution of end-use consumption in the buildings sector for 2025 and the resulting $\mathrm{CO}_{2}$ emissions footprint. The distributions differ slightly from those in the Annual Energy Outlook, as they are derived, in part, from BT's Buildings Energy Data Book. (For example, the AEO categories of PC and non-PC office equipment have been combined in the flow chart.) More complete documentation of the energy flow charts is provided in a separate PNNL report. ${ }^{2}$ This documentation discusses more fully how the electricity sector is treated as well as how the Buildings Energy Data Book was used to allocate end-use energy consumption in the buildings sector.

Figures 8.2 and 8.3 show the projected energy flows in the buildings sector under the Lost Opportunities case. The reduction in the key energy uses is illustrated in Figure 8.3 with the dotted outline of the Reference Case flows, consistent with Figure 8.1. The major impact of the Lost Opportunities case is reflected in the reduction in fossil fuel inputs to the electricity sector. In developing the flow chart, and with examination of Tables 4 and 5 of the AEO 2008, PNNL assumed that the entire reduction in electricity generation would come from fossil generation sources. The resulting change in the $\mathrm{CO}_{2}$ emissions footprint also appears in Figure 8.3.

This fossil generation assumption is consistent with the projected mix of new generation sources in the 2008 Annual Energy Outlook. For the twenty-year period between 2005 and 2025, the reference case shows that more than $90 \%$ of new capacity in the electric power sector is expected to be supplied by fossil fuel plants. (These are unplanned additions to capacity - additions not currently announced by utilities [see Table A9 of the $2008 \mathrm{AEO}$ ]). With increasing concern over $\mathrm{CO}_{2}$ emissions, it does not seem likely that the increase in other generation sources - nuclear and renewables - would be greatly impacted by slower growth in electricity demand. The reduction in fossil fuel inputs stems from both the reduction in end-use (delivered) electricity as well as a significant contribution from photovoltaic technologies.

\footnotetext{
${ }^{1}$ This treatment avoids showing the fictitious amount of energy that is presumed to be "lost" in the process of generating electricity by these technologies. (Transmission and distribution losses, however, are reflected in the figure.) This approach also provides an approximate graphical representation of the carbon emission impacts of commercial energy use, as there are no carbon emissions from nuclear, hydro, or renewable technologies.

${ }^{2}$ DB Belzer, 2006, Energy End-Use Flow Maps for the Buildings Sector. PNNL-16263, Pacific Northwest National Laboratory, Richland, WA. http://www.pnl.gov/main/publications/external/technical_reports/PNNL-16263.pdf
} 


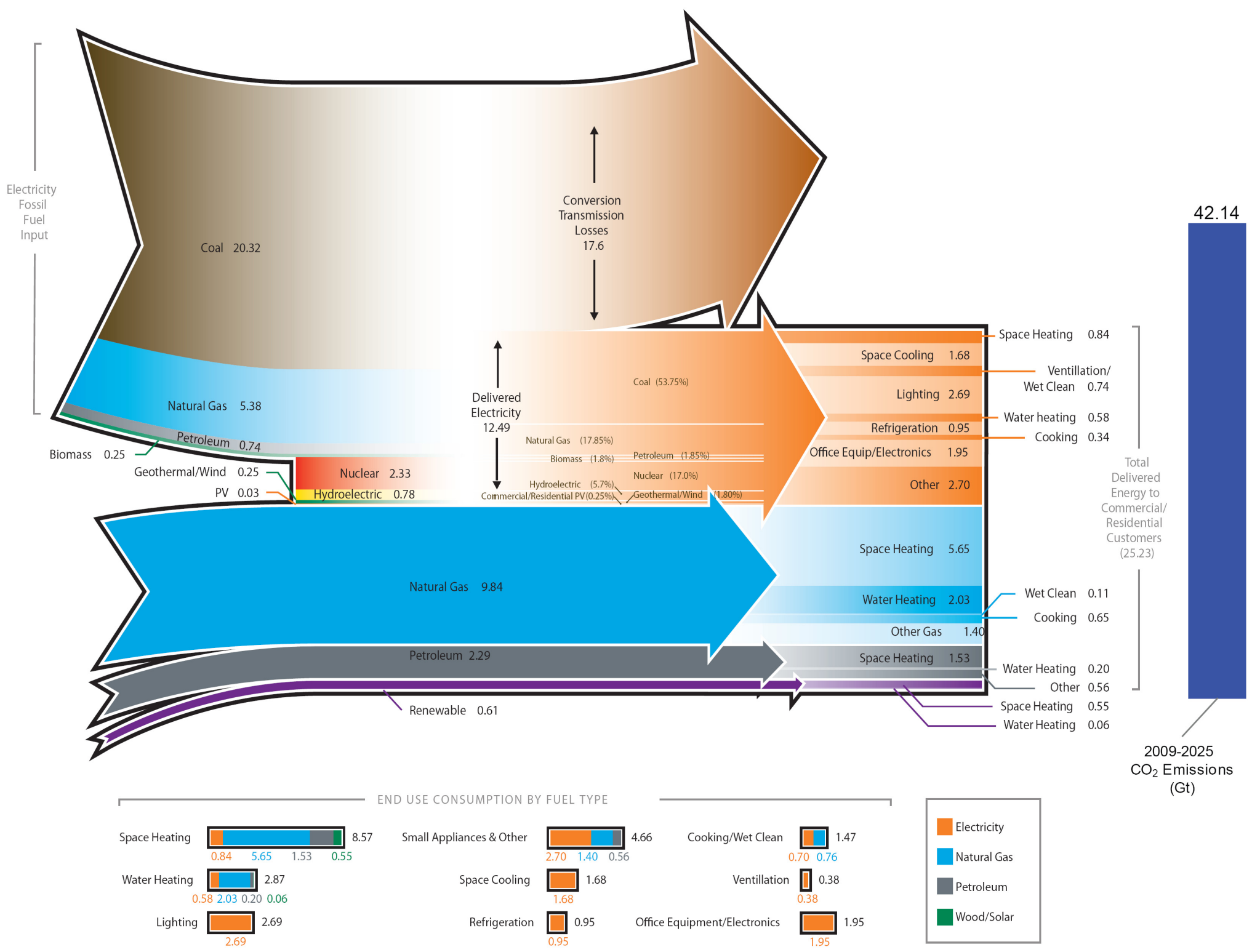

Figure 8.1. 2025 Buildings Sector Energy Flow from Source to End Use (based on AEO 2008 Reference Case) 


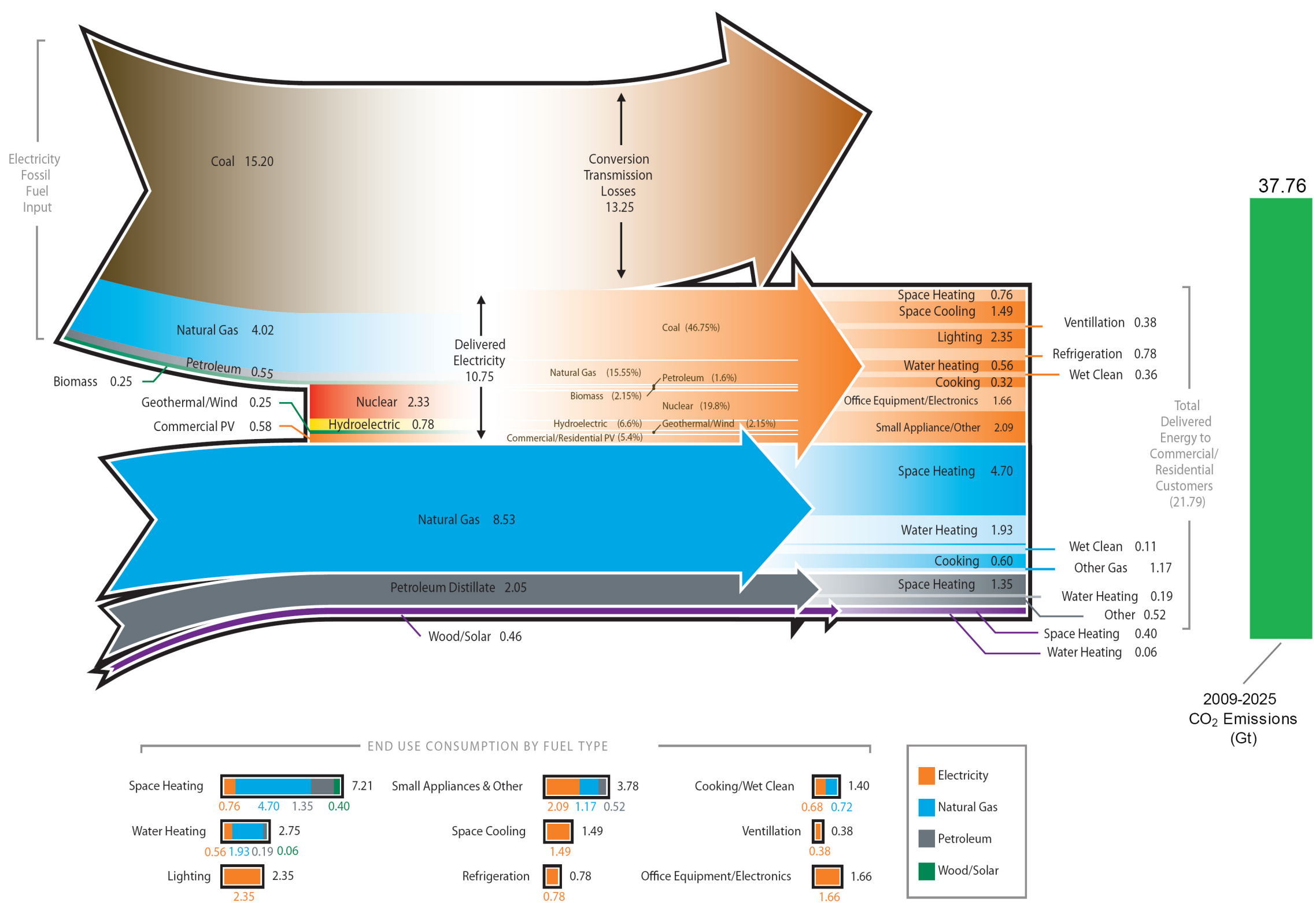

Figure 8.2. 2025 Buildings Sector Energy Flow from Source to End Use under the BT Lost Opportunities Case 


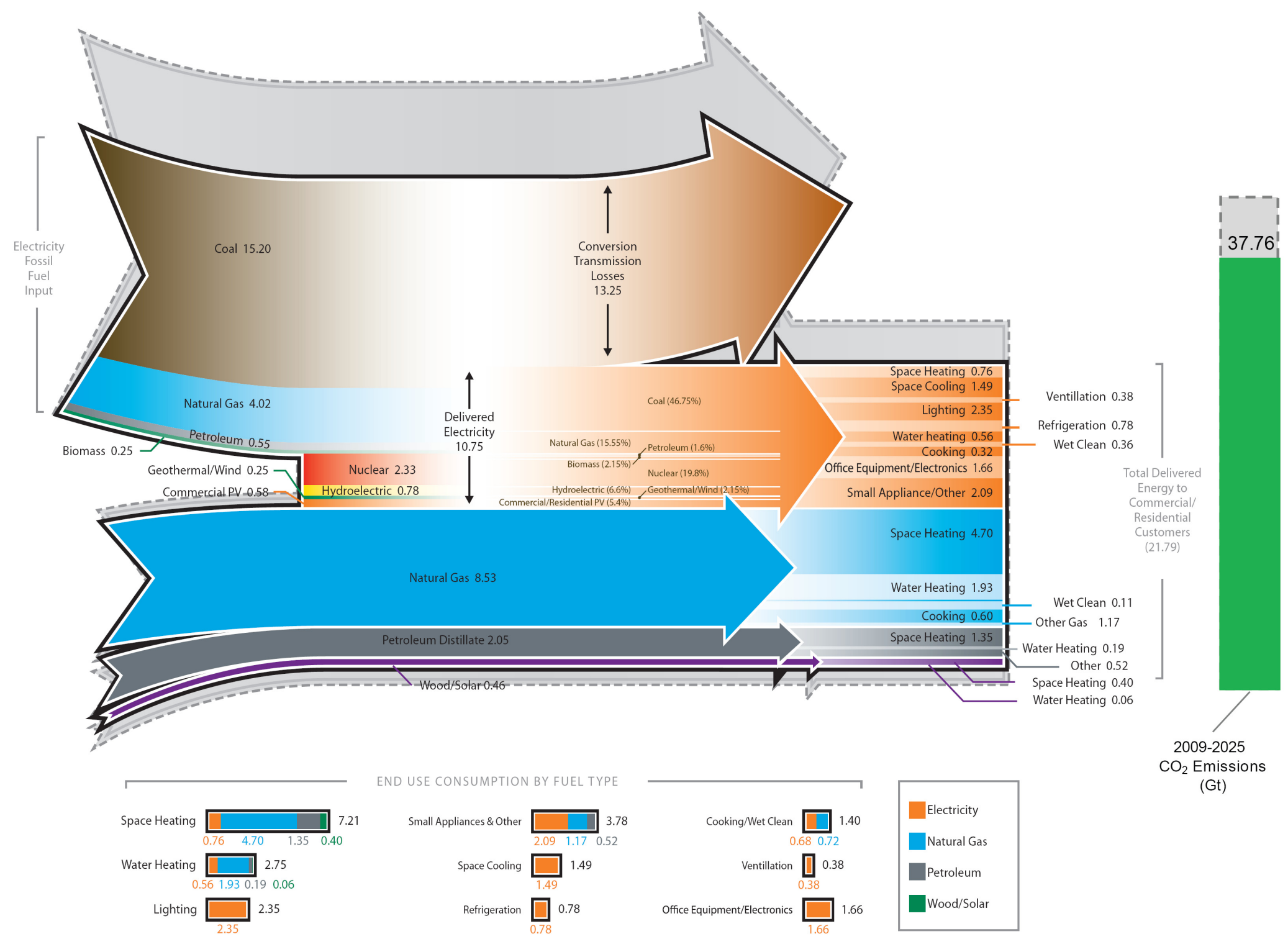

Figure 8.3. Change in 2025 Buildings Sector Energy Flows between AEO 2008 Reference Case (footprint shown) and the BT Lost Opportunities Case 


\section{Appendix A \\ Projected Miscellaneous Electricity Consumption in the Commercial Sector}

Memo, from David Belzer, PNNL, to John Ryan, EERE/BTP, et al.

July 11, 2007 



\title{
Appendix A
}

\section{Projected Miscellaneous Electricity Consumption in the Commercial Sector}

\author{
Date: July 11, 2007 \\ To: John Ryan, EERE/BTP \\ From: David Belzer, PNNL (509/372-4254, david.belzer@pnl.gov) \\ Ce: $\quad$ Dru Crawley, EERE/BTP \\ Erin Boedecker, EIA \\ Andrew Nicholls, PNNL \\ Mark Halverson, PNNL \\ Jordan Kelso, D\&R International \\ Edward Barbour, Navigant Consulting
}

Subject: Projected Miscellaneous Electricity Consumption in the Commercial Sector

On June 22, Andrew and I met with you to discuss my commercial buildings electric intensities presentation, EIA's large miscellaneous electric end-uses, and EIA data issues generally. At the meeting, I committed to follow-up with further investigation of EIA's projections of miscellaneous electric load growth. This memo represents my findings to date. Realizing that everyone's time is very valuable, and that you may only have time to skim this memorandum, I have endeavored to "highlight" key findings or passages in yellow. Also, please note the "Conclusions" section that begins on page 10.

\section{Issue: Very High Growth of Miscellaneous Electricity Consumption in the AEO 2007}

The NEMS commercial model disaggregates electricity use in the commercial sector into 10 distinct end uses. As shown in Table A.1, a very large percentage of electricity use is classified as office equipment (PC and non-PC) and "other" uses. These three end uses are now estimated to comprise over $40 \%$ of all commercial sector electricity use. By 2030, these end uses are projected to account for well over half (56\%) of all commercial sector electricity use.

Office equipment is projected to grow faster than any other end use over the next 25 years. The annual growth rate for PC equipment is expected to grow at $3.0 \%$ per year from 2005 to 2030; the growth rate of non-PC office equipment is projected at $3.6 \%$ over the same period. The growth rate of non-PC equipment includes growth in the electricity use for server farms and other high-intensity data centers. The projected growth in electricity for "other" is somewhat lower, at $2.3 \%$ per year, but is still larger than any other end use with the exception of the two office equipment categories. Because it is a very large category, currently accounting for almost $30 \%$ of total commercial sector energy use, it is important to understand the assumptions and data that go into these estimates and projections. The Building Technologies Program (BTP) is particularly interested in this category as the potential for reducing these loads is critical in achieving true "net zero energy" commercial buildings in the future. 
Table A.1. Commercial Sector Electricity Projections in AEO 2007

\begin{tabular}{lcc|cc} 
& \multicolumn{2}{c|}{$\begin{array}{c}\text { Quadrillion Btu } \\
\text { (delivered) }\end{array}$} & \multicolumn{2}{c}{ Share of Total } \\
\multicolumn{1}{c|}{ End Use } & 2005 & 2030 & 2005 & 2030 \\
\hline Space Heating 1/ & 0.17 & 0.19 & $3.9 \%$ & $2.7 \%$ \\
Space Cooling 1/ & 0.55 & 0.61 & $12.7 \%$ & $8.6 \%$ \\
Water Heating 1/ & 0.18 & 0.20 & $4.1 \%$ & $2.8 \%$ \\
Ventilation & 0.19 & 0.25 & $4.3 \%$ & $3.5 \%$ \\
Cooking & 0.04 & 0.04 & $0.9 \%$ & $0.5 \%$ \\
Lighting & 1.18 & 1.51 & $27.3 \%$ & $21.5 \%$ \\
Refrigeration & 0.23 & 0.30 & $5.4 \%$ & $4.3 \%$ \\
Office Equipment (PC) & 0.18 & 0.40 & $4.2 \%$ & $5.8 \%$ \\
Office Equipment (non-PC) & 0.35 & 0.92 & $8.2 \%$ & $13.0 \%$ \\
Other Uses 2/ & 1.25 & 2.62 & $29.0 \%$ & $37.3 \%$ \\
\hline \multicolumn{1}{c}{ Total } & 4.32 & 7.03 & $100.0 \%$ & $100.0 \%$
\end{tabular}

\section{Breakdown of Other Electricity Use}

At present, EIA is somewhat cryptic as to the composition of "Other Uses". In the footnote describing the composition of this consumption, we read:

Includes miscellaneous uses, such as service station equipment, automated teller machines, telecommunication equipment, medical equipment, pumps, .... (remainder of uses apply to purchased fuels-italics added)

EIA has been aware of the amorphous nature of this category and begun to take steps to better identify the amounts of energy used by specific types of miscellaneous equipment. In 2006, TIAX completed an EIA-funded study that developed estimates of current and future electricity consumption for nine types of equipment in the commercial sector. The results of this work were summarized in the section of the 2007 AEO entitled "Issues in Focus." 44 Table A.2 reproduces the table in the 2007 AEO (Table 5) that shows the 2005, 2015 and 2030 estimates for the commercial sector. ${ }^{45}$

The AEO table was shown in terms of billion $\mathrm{kWh}$ (or terra-watt hours, TWh), for which one needs to be mindful. When converted to Btu, the numbers for the "Total Miscellaneous" category and total commercial sector electricity in Table A.2 match the last two rows in Table A.1 (where "Other Uses" is equivalent to the bold "Total Miscellaneous" in Table A.2).

\footnotetext{
${ }^{44}$ See page 46 and the discussion of Table 7 of http://www.eia.doe.gov/oiaf/aeo/pdf/issues.pdf

${ }^{45} \mathrm{http}$ ://www.eia.doe.gov/oiaf/aeo/pdf/appa.pdf
} 
Table A.2. Miscellaneous Electricity Uses in the Commercial Sector, 2005, 2015 and 2030

\begin{tabular}{lccc} 
Billion kWh (= TWh) & & & \\
Electricity use & 2005 & 2015 & 2030 \\
\hline Coffee Makers & 2.7 & 3 & 3.5 \\
Distribution Transformer & 54.5 & 54.6 & 54.9 \\
Non-road electric vehicles & 4 & 5.2 & 7.1 \\
MRI equipment & 0.6 & 1.9 & 4.5 \\
CT scanners & 0.9 & 1.8 & 2.8 \\
X-ray machines & 4 & 6.8 & 12 \\
Elevators & 4.4 & 4.7 & 5.5 \\
Escalators & 0.7 & 0.8 & 1 \\
Water Supply \& Treatment & 65.6 & 68.5 & 75.5 \\
\hline Total, from TIAX report & 137.4 & 147.3 & 166.8 \\
Other Misc. Uses & 229.5 & 357.9 & 601.6 \\
Total Miscellaneous & $\mathbf{3 6 6 . 9}$ & $\mathbf{5 0 5 . 2}$ & $\mathbf{7 6 8 . 4}$ \\
Total commercial sector & 1266.7 & 1548.2 & 2061.6
\end{tabular}

The end uses covered by the TIAX report cover just over a third of miscellaneous (i.e., "other") electricity use in 2005. By 2030, that fraction falls to just over $20 \%$. As Table A. 2 indicates, the total consumption of the end uses studied (and projected) by TIAX increases relatively modestly through 2030 . While electricity use in medical equipment is projected to increase substantially, the growth in electricity for distribution transformers is very small. In large part, the small increase in consumption for transformers is due to the EPACT 2005 legislation that includes efficiency standards for low-voltage drytype distribution transformers.

Given the modest growth in the end uses covered by TIAX, the principal issue is why does the remainder of the miscellaneous category show such rapid growth over the next two decades? From $230 \mathrm{TWh}$ in 2005, this category increases to over $600 \mathrm{TWh}$ in 2030.

The discussion below will help to sort out the various aspects of this growth.

\section{Non-Building Use}

While there is no explicit mention of non-building energy use in the AEO report tables, the NEMS commercial model does incorporate an estimate. Labeled by EIA as non-building use, this energy is more correctly considered to include both non-building use as well as the statistical discrepancy between the supply-survey and CBECS estimates of total commercial (sector) energy use.

The end-use disaggregation of all energy types for both the residential and commercial modules in NEMS is based on the most recent RECS and CBECS surveys. In the commercial model, the most recent detailed estimates of end use consumption by fuel, building type, and census division were made for the 1995 CBECS. Partial updates of those estimates have been made by EIA for the 1999 and 2003 CBECS. Lacking consumption estimates from the 2003 CBECS, the AEO 2007 version of the NEMS commercial model is largely based upon the estimates from the 1999 CBECS. For 1999, the supply survey estimates for electricity (as produced by EIA for the State Energy Data System and published in the Annual Energy Review) were considerably higher than those in the 1999 CBECS. At a national level, the supply survey 
estimate for delivered electricity was 3,768 TBtu; the CBECS estimate for electricity was 3098 Tbtu, a difference of 670 Tbtu. ${ }^{46}$

In preparing a projection for the $\mathrm{AEO}$, the commercial model generates energy consumption estimates starting in 2004 (one year past the most recent CBECS). Using the base year (2003) estimates of consumption by end use, fuel, building type, and region, the model generates forecast numbers for each subsequent year. Actual data for the commercial sector was available for 2005 by the fall of 2006 when the AEO was prepared.

In addition to the actual data for 2005, EIA's forecasts from the Short Term Energy Outlook (STEO) were also available through 2007. Without trying to understand EIA's methodology completely by looking over the FORTRAN code in the NEMS commercial model, it appears to me that there may be a two-stage benchmarking procedure. In the first stage, the NEMS projections are definitely benchmarked to the 2005 annual consumption estimate (as published in the Annual Energy Review [AER] in the summer of 2006). In the second stage, there may be some additional adjustments to help align the AEO with the STEO. It appears from the code that the magnitude of the second set of adjustment factors (used to achieve consistency with the STEO in 2006 and 2007) is reduced over time.

For 2005, the difference at the national level between the AER and the NEMS commercial model projection is about $680 \mathrm{TBtu}$ for site level electricity. These values are labeled as non-building energy consumption inside the commercial model code. While it is clear that the difference does include nonbuilding energy use, it also incorporates all of the other discrepancies between supply survey and CBECS estimates of energy use. Moreover, it includes any NEMS forecasting errors between the 2003 base year and 2005. The bottom line is that the 2005 differences are best viewed as calibration quantities for consistency to the supply survey estimates (reflected by the STEO) of broad end use sector consumption rather any independent estimate of non-building consumption.

EIA basically projects this "non-building" energy use for years beyond 2005 to grow at the same rate of total floor space in each census division. In reality, two further adjustments are made prior to making these projections. Because the TIAX report also considered water supply and treatment (a major nonbuilding commercial electricity use), the 2005 estimate of the electricity consumption for these uses is subtracted from the total "non-building use". Estimated electricity use for traffic signals is also subtracted.

For future years, the total "non-building" use is then projected separately for these three components. TIAX provided projections of water supply and treatment ("water services") through 2030. Electricity use for traffic signals is assumed to decline linearly through 2015, apparently reflecting standards in EPACT 2005. All "other" non-building energy use is assumed to essentially increase in proportion to floor space. There is not a strict proportional increase with respect to floor space because a price elasticity adjustment is applied to the non-specific portion of non-building energy use.

\footnotetext{
${ }^{46}$ For more information on the differences between EIA's supply and demand side estimates for commercial, see DB Belzer, Estimates of U.S. Commercial Building Electricity Intensity Trends: Issues Related to End-Use and Supply Surveys . September 2007. PNNL-16820, Pacific Northwest National Laboratory, Richland, WA http://www.pnl.gov/main/publications/external/technical reports/PNNL16820.pdf
} 


\section{Disaggregation of Other Electricity Consumption Based upon Published Data}

Given an estimate of non-building energy use that can be determined by examining the various printed output from the NEMS commercial model, we can then attempt to categorize the various components of the "Other" electricity use. With the estimates of non-building electricity use in hand, we can then estimate the "Within Building" electricity by subtraction (using the values in Table A.2).

Table A.3 shows the results of this high-level disaggregation. The top panel of the table is shown in terms of TWh to be consistent with Table A.2 (i.e., the table in the 2007 AEO). The next panel shows the values converted to quadrillion Btu. We shall discuss the table in terms of Btu for consistency with the majority of AEO tables related to commercial sector energy consumption.

Given the estimate of 1.25 QBtu for total miscellaneous electricity use, the "within building" use is calculated by subtracting the non-building use of 0.68 QBtu. That leaves 0.57 QBtu for these uses. TIAX estimated 0.24 QBtu in 2005 for the first eight end uses shown in Table A.2 (i.e., all uses except water services). That leaves a residual amount of $0.33 \mathrm{QBtu}$.

For the non-building sub-aggregate, the total electricity consumption is split into $0.22 \mathrm{QBtu}$ for water services and $0.45 \mathrm{QBtu}$ for all other uses. (This includes traffic signals that we did not try to determine from the NEMS model coding).

The last column of the table shows the percentage change in the electricity consumption between 2005 and 2030 as projected in the 2007 AEO. The most striking value is obviously the $327 \%$ increase in electricity consumption for the non-specific portions of miscellaneous electricity within buildings.

The other elements of miscellaneous electricity use appear to be reasonable on the surface. The total of the "within building" uses identified by TIAX grow from 0.24 QBtu to $0.31 \mathrm{QBtu}$. This modest growth is solely the result of more efficient distribution transformers (as shown in Table A.2). The very small increase in electricity use for transformers offsets fairly large projected percentage increases for medical equipment (also shown in Table A.2).

For non-building use, the electricity consumption for water services is projected to increase by only $15 \%$ from 2005 to 2030 (derived solely from the TIAX analysis). Other miscellaneous non-building use grows by $43 \%$, just slightly less than the $45 \%$ growth in total floor space (shown in the last panel in the table.) As mentioned above, the slight decline in overall implied intensity results from more efficient (LED) traffic signals as well as some influence from higher electricity prices in the out years of the forecast.

\section{Within-building Miscellaneous Electricity Growth (non-TIAX)}

Table A.3 clearly points to the projected growth of miscellaneous uses in buildings, not covered by TIAX, as being the major element in the overall growth in the "Other Uses" line item in the standard AEO tables for commercial electricity consumption. At the bottom of Table A.3, we show the implied increase in overall intensity from this element.

Across all buildings, the intensity of this usage category grows from $4.42 \mathrm{kBtu} / \mathrm{sq}$. $\mathrm{ft}$. to 12.97 $\mathrm{kBtu} / \mathrm{sq}$. ft. Shown in the last line of the table, this implied a relative growth factor of nearly 3 between 2005 and 2030 (2030/2005). 
The obvious question is, what assumptions is EIA making to drive this enormous growth in this element of electricity use? The answer seems to be that EIA primarily relies upon a set of user-specified "market penetration" factors for office equipment (PC and non-PC) and miscellaneous energy use (not covered by TIAX). These factors essentially are multipliers of the "service demand" (i.e., electricity use per square foot) in the base year-here defined by the latest CBECS as 2003. These factors are shown in Table A.4. While PC equipment shows the largest increase in percentage

Table A.3. Major Categories of "Other" Electricity Use

\begin{tabular}{|c|c|c|c|c|}
\hline Electricity use (TWh) & 2005 & 2015 & 2030 & $\begin{array}{c}\% \text { Chg } 2005 \text {. } \\
2030\end{array}$ \\
\hline Electricity Misc Use & 366.9 & 505.2 & 768.4 & $109 \%$ \\
\hline Within Building & 168.0 & 281.1 & 502.1 & $199 \%$ \\
\hline TIAX report & 71.8 & 78.8 & 91.3 & $27 \%$ \\
\hline Other & 96.2 & 202.3 & 410.8 & $327 \%$ \\
\hline Non-Building & 198.9 & 224.1 & 266.3 & $34 \%$ \\
\hline TIAX (water services) & 65.6 & 68.5 & 75.5 & $15 \%$ \\
\hline \multirow[t]{2}{*}{ Other non-building } & 133.3 & 155.6 & 190.8 & $43 \%$ \\
\hline & 2005 & 2015 & 2030 & $\begin{array}{c}\text { \% Chg } 2005 \text {. } \\
2030\end{array}$ \\
\hline Electricity Misc Use & 1.25 & 1.72 & 2.62 & $109 \%$ \\
\hline Within Building & 0.57 & 0.96 & 1.71 & $199 \%$ \\
\hline TIAX report & 0.24 & 0.27 & 0.31 & $27 \%$ \\
\hline Other & 0.33 & 0.69 & 1.40 & $327 \%$ \\
\hline Non-Building & 0.68 & 0.76 & 0.91 & $34 \%$ \\
\hline TIAX (water services) & 0.22 & 0.23 & 0.26 & $15 \%$ \\
\hline Other non-building & 0.45 & 0.53 & 0.65 & $43 \%$ \\
\hline Electricity use (\% of Total) & 2005 & 2015 & 2030 & \\
\hline Electricity Misc Use & $29.0 \%$ & $32.6 \%$ & $37.3 \%$ & \\
\hline Within Building & $13.3 \%$ & $18.2 \%$ & $24.4 \%$ & \\
\hline TIAX report & $5.7 \%$ & $5.1 \%$ & $4.4 \%$ & \\
\hline Other & $7.6 \%$ & $13.1 \%$ & $19.9 \%$ & \\
\hline Non-Building & $15.7 \%$ & $14.5 \%$ & $12.9 \%$ & \\
\hline TIAX (water services) & $5.2 \%$ & $4.4 \%$ & $3.7 \%$ & \\
\hline Other non-building & $10.5 \%$ & $10.1 \%$ & $9.3 \%$ & \\
\hline $\begin{array}{l}\text { Floor Space (Billion Sq. Ft.) } \\
\text { Within Building - Other }\end{array}$ & 74.28 & 86.54 & 108.03 & $45 \%$ \\
\hline Ave. Intensity (kBtu/sf) & 4.42 & 7.98 & 12.97 & \\
\hline Index, $2005=1$ & & 1.80 & 2.93 & \\
\hline
\end{tabular}

Table A.4. Market Penetration Factors for Office Equipment and Miscellaneous Uses

\begin{tabular}{llllll} 
End-use category & 2003 & 2005 & 2010 & 2015 & 2030 \\
\hline Office Equipment (PC) & 1.00 & 2.18 & 3.35 & 3.56 & 3.34 \\
Office Equipment (non-PC) & 1.00 & 1.11 & 1.39 & 1.54 & 2.00 \\
Miscellaneous & 1.00 & 1.12 & 1.47 & 1.78 & 2.65
\end{tabular}


terms between 2005 and 2030 (increasing by a factor of 3.3), the assumed growth in the miscellaneous category is also very large. Combining the results of Table A.1 and Table A.3, the base year (2005) consumption for the miscellaneous "within-building" electricity is estimated to be about double that for PC equipment (0.33 QBtu vs. 0.18 QBtu.)

Some considerable effort was expended to try to understand the apparent inconsistency between the user-supplied market penetration factors for miscellaneous equipment (where the ratio of 2030 to 2005 is 2.36) and implied increase in intensity shown at the bottom of Table A.2 $(2030 / 2005=2.93)$. Because there are no real measures of "efficiency" projected for this end-use category, an increase in market penetration is equivalent to an increase in the energy intensity of the equipment (as defined by $\mathrm{kBtu} / \mathrm{sq} . \mathrm{ft}$.). All metrics are expressed solely in terms of kBtu per square foot of floor space (as contrasted to say, heating and cooling equipment, where Btu delivered to the equipment is distinguished from Btu delivered to the building space).

Unfortunately, I have not been able to develop an entirely satisfactory explanation of this discrepancy. Several factors may be responsible. The first is that the version of the commercial model downloaded from the EIA web site does not precisely yield the published estimates of total electricity use in the AEO. For the "Other Uses" line item in Table A.1, the PNNL version shows total 2030 electricity use of 2.67 QBtu versus the 2.62 QBtu published in AEO 2007. However, there seem to be other incongruities that are likely more responsible for the discrepancy. These include a model estimate of distribution transformer electricity use that does not appear to match the TIAX estimate as well as a possible omission of a line of code in the section of the model dealing with the TIAX projections for medical equipment. As time permits, these issues will be discussed with Erin Boedecker to try to resolve.

One method to try to understand the behavior of the miscellaneous uses not covered in the TIAX report is to run the model with a modification that omits the TIAX end uses. Thus, we can generate an estimate of the miscellaneous end use that results solely from the EIA assumptions about market penetration (Table A.4).

Table A.5 shows the results of such a model run and displays the electricity consumption (TBtu) by building type and census division. Running the model in this fashion yields some differences in the total amount of electricity projected by NEMS for miscellaneous use as compared to estimates shown in Table A.3. For 2005, the total use is calculated to be $433 \mathrm{TBtu}(0.43 \mathrm{QBtu})$. This is considerably higher than the estimate of the same category in Table A.2 that was derived as a residual (0.33 QBtu).

The third panel shows the ratios of the 2030 to the 2005 consumption. These differ by building type and census division because the growth rates of floor space differ over the forecast period. The consumption values in the first two panels are intended to show the magnitude of the electricity consumption in the beginning and terminal years of the forecast.

To take out most of the effects of different growth rates of floor space by region, in the last line of the table we show the implied increases in energy per square foot by building type for the U.S. as a whole. Across all building types, the ratio of the 2030 intensity to the 2005 intensity is 2.38 (see bottom right value). This value is very close to the magnitude we would expect from the market penetration factors shown in Table A.4, where the ratio between 2030 and 2005 is 2.36. The electricity consumption for this end use is also subject to adjustment based upon price elasticities (and regional compositional effects) so we would not expect the ratios to be identical. The bottom line, however, is that the values in the table 
(taken from special version of the model that excludes the TIAX-covered equipment) are more consistent with user inputs than those developed from using the published aggregates.

Table A.5. Miscellaneous Electricity by Building Type and Census Division

\begin{tabular}{|c|c|c|c|c|c|c|c|c|c|c|c|c|}
\hline 2005 & Assembly & Education & $\begin{array}{l}\text { Food } \\
\text { Sales }\end{array}$ & $\begin{array}{l}\text { Food } \\
\text { Service }\end{array}$ & $\begin{array}{c}\text { Health } \\
\text { Care }\end{array}$ & Lodging & $\begin{array}{l}\text { Large } \\
\text { Office }\end{array}$ & $\begin{array}{l}\text { Small } \\
\text { Office }\end{array}$ & $\begin{array}{l}\text { Merc./ } \\
\text { Service }\end{array}$ & $\begin{array}{c}\text { Wareh } \\
\text { ouse }\end{array}$ & Other & Total \\
\hline New England & 0.7 & 0.6 & 0.6 & 0.4 & 0.1 & 2.0 & 3.3 & 2.6 & 4.8 & 0.3 & 5.7 & \\
\hline Mid-Atlantic & 2.5 & 4.9 & 1.2 & 1.3 & 1.6 & 2.9 & 16.9 & 7.9 & 9.5 & 2.8 & 9.6 & \\
\hline East N. Central & 4.3 & 6.4 & 1.8 & 3.2 & 2.2 & 4.6 & 13.3 & 6.6 & 6.2 & 4.8 & 5.0 & \\
\hline West N. Central & 1.8 & 2.1 & 1.0 & 0.9 & 0.7 & 3.1 & 2.8 & 6.9 & 4.2 & 3.2 & 2.4 & \\
\hline South Atlantic & 6.0 & 13.1 & 1.9 & 5.9 & 3.1 & 6.7 & 14.6 & 9.1 & 23.1 & 6.5 & 10.5 & \\
\hline East S. Central & 3.0 & 1.3 & 0.9 & 1.3 & 0.9 & 3.1 & 2.5 & 4.3 & 6.1 & 0.8 & 2.5 & \\
\hline West S. Central & 3.5 & 7.1 & 1.4 & 4.5 & 1.4 & 3.4 & 12.5 & 5.0 & 10.8 & 3.7 & 3.2 & \\
\hline Mountain & 1.6 & 3.0 & 0.5 & 0.3 & 0.6 & 3.6 & 3.0 & 5.6 & 9.7 & 2.3 & 1.1 & \\
\hline Pacific & 3.0 & 3.0 & 0.7 & 2.5 & 0.9 & 3.9 & 9.8 & 7.3 & 10.1 & 2.3 & 4.5 & \\
\hline Total (TBtu) & 26.4 & 41.3 & 9.9 & 20.6 & 11.4 & 33.2 & 78.7 & 55.4 & 84.4 & 26.7 & 44.7 & 432.7 \\
\hline 2030 & Assembly & Education & $\begin{array}{l}\text { Food } \\
\text { Sales }\end{array}$ & $\begin{array}{c}\text { Food } \\
\text { Service }\end{array}$ & $\begin{array}{c}\text { Health } \\
\text { Care }\end{array}$ & Lodging & $\begin{array}{l}\text { Large } \\
\text { Office }\end{array}$ & $\begin{array}{l}\text { Small } \\
\text { Office }\end{array}$ & $\begin{array}{l}\text { Merc./ } \\
\text { Service }\end{array}$ & $\begin{array}{c}\text { Wareh } \\
\text { ouse }\end{array}$ & Other & \\
\hline New England & 1.8 & 1.8 & 1.6 & 1.2 & 0.4 & 7.3 & 9.7 & 7.8 & 14.2 & 1.0 & 24.0 & \\
\hline Mid-Atlantic & 5.5 & 12.8 & 3.2 & 3.6 & 5.4 & 8.7 & 42.2 & 20.3 & 25.8 & 8.0 & 36.0 & \\
\hline East N. Central & 12.3 & 19.4 & 5.4 & 10.0 & 7.6 & 15.3 & 36.6 & 18.6 & 19.3 & 15.3 & 20.8 & \\
\hline West N. Central & 5.0 & 7.3 & 2.9 & 2.9 & 2.1 & 10.6 & 8.2 & 20.7 & 13.1 & 10.0 & 9.9 & \\
\hline South Atlantic & 22.7 & 54.8 & 7.4 & 23.7 & 13.3 & 25.0 & 59.0 & 37.0 & 95.0 & 28.6 & 40.7 & \\
\hline East S. Central & 8.9 & 4.5 & 3.3 & 4.9 & 3.2 & 11.8 & 7.7 & 13.4 & 21.3 & 3.2 & 12.4 & \\
\hline West S. Central & 11.5 & 29.6 & 4.7 & 15.4 & 6.0 & 11.0 & 32.9 & 13.9 & 39.6 & 12.2 & 13.7 & \\
\hline Mountain & 6.4 & 10.5 & 2.0 & 1.5 & 2.7 & 19.5 & 10.4 & 19.5 & 42.6 & 8.9 & 5.8 & \\
\hline Pacific & 9.4 & 10.3 & 2.4 & 7.9 & 3.2 & 13.9 & 27.6 & 20.8 & 37.1 & 9.8 & 15.9 & \\
\hline Total (TBtu) & 83.5 & 151.0 & 33.0 & 71.0 & 43.7 & 123.0 & 234.5 & 172.1 & 308.0 & 97.0 & 179.4 & 1496.0 \\
\hline \multicolumn{13}{|l|}{ Ratio of 2030 to 2005} \\
\hline & Assembly & Education & $\begin{array}{l}\text { Food } \\
\text { Sales }\end{array}$ & $\begin{array}{c}\text { Food } \\
\text { Service }\end{array}$ & $\begin{array}{c}\text { Health } \\
\text { Care }\end{array}$ & Lodging & $\begin{array}{l}\text { Large } \\
\text { Office }\end{array}$ & $\begin{array}{l}\text { Small } \\
\text { Office }\end{array}$ & $\begin{array}{l}\text { Merc./ } \\
\text { Service }\end{array}$ & $\begin{array}{l}\text { Wareh } \\
\text { ouse }\end{array}$ & Other & \\
\hline New England & 2.5 & 3.0 & 2.8 & 2.8 & 5.2 & 3.7 & 2.9 & 3.0 & 2.9 & 3.0 & 4.2 & \\
\hline Mid-Atlantic & 2.2 & 2.6 & 2.7 & 2.7 & 3.3 & 3.0 & 2.5 & 2.6 & 2.7 & 2.9 & 3.7 & \\
\hline East N. Central & 2.9 & 3.0 & 3.1 & 3.1 & 3.5 & 3.3 & 2.8 & 2.8 & 3.1 & 3.2 & 4.1 & \\
\hline West N. Central & 2.8 & 3.5 & 3.0 & 3.0 & 3.1 & 3.4 & 3.0 & 3.0 & 3.1 & 3.1 & 4.2 & \\
\hline South Atlantic & 3.8 & 4.2 & 4.0 & 4.0 & 4.3 & 3.8 & 4.1 & 4.1 & 4.1 & 4.4 & 3.9 & \\
\hline East S. Central & 3.0 & 3.6 & 3.6 & 3.6 & 3.6 & 3.8 & 3.1 & 3.1 & 3.5 & 4.2 & 4.9 & \\
\hline West S. Central & 3.3 & 4.2 & 3.4 & 3.4 & 4.4 & 3.3 & 2.6 & 2.8 & 3.7 & 3.3 & 4.4 & \\
\hline Mountain & 3.9 & 3.5 & 4.2 & 4.2 & 4.3 & 5.4 & 3.5 & 3.5 & 4.4 & 4.0 & 5.1 & \\
\hline Pacific & 3.2 & 3.4 & 3.2 & 3.2 & 3.7 & 3.5 & 2.8 & 2.8 & 3.7 & 4.3 & 3.5 & \\
\hline Total & 3.2 & 3.7 & 3.3 & 3.4 & 3.8 & 3.7 & 3.0 & 3.1 & 3.6 & 3.6 & 4.0 & 3.5 \\
\hline \multicolumn{13}{|l|}{ Intensity (kBtu/sf) } \\
\hline US Total - 2005 & 3.3 & 4.0 & 7.6 & 12.0 & 5.7 & 6.3 & 11.3 & 8.2 & 5.3 & 2.6 & 7.9 & 5.8 \\
\hline US Total -2030 & 8.3 & 9.8 & 18.0 & 28.8 & 13.5 & 15.1 & 26.9 & 19.6 & 12.8 & 6.2 & 18.8 & 13.8 \\
\hline Ratio (2030/2005) & 2.47 & 2.46 & 2.37 & 2.40 & 2.37 & 2.40 & 2.38 & 2.38 & 2.42 & 2.41 & 2.36 & 2.38 \\
\hline
\end{tabular}

\subsection{Conclusions}

The results of this investigation can be summarized as follows:

- "Other Uses" in the AEO standard tables includes both building and "non-building" use where nonbuilding use is essentially the statistical discrepancy between CBECS and supply-survey estimates of commercial sectors electricity use

- "Non-building" use is projected entirely within the NEMS commercial module, based upon overall floor space growth and TIAX projections of "water services" electricity 
- Miscellaneous electricity use "within" buildings is generated by two methods: 1) TIAX projections of distribution transformers and seven other specified uses, and 2) EIA projections of market penetration for all other non-specified uses.

The large projected increases for the office equipment and miscellaneous uses are almost entirely based upon assumed increases in the "amount" of such equipment per unit of floor area. To my knowledge, the specific rationale for the assumed increases in market penetration is not spelled out by EIA. ${ }^{47}$ EIA would likely welcome some help to better identify this equipment and to improve the means to predict future trends in efficiency and market penetration. In essence, this may involve future work with TIAX or others.

As shown in the inputs and outputs from the AEO 2007 version of NEMS, miscellaneous end uses (other than those considered by TIAX) currently may be as high as $10 \%$ of total electricity use in commercial buildings. We must remind ourselves that this result does not derive from any large sample of buildings with metered end-use consumption. So whether this estimate of the amount of electricity currently used for these miscellaneous uses is even reasonably accurate is open to question. The bottom line is that any attention required by BT to this component of commercial building electricity use depends upon both the magnitude of current consumption as well as any credible projection of future consumption. Both of these elements currently are based upon very weak empirical evidence. A major question is whether the forthcoming work to develop end use consumption estimates for the 2003 CBECS will be able to come up with more defensible values.

The analysis here supports the suggestion that EIA should be encouraged to improve its reporting in the AEO. The current footnote devoted to "Other Uses" does not make clear that this entry includes miscellaneous electricity within buildings, non-building use, and a statistical discrepancy between EIA data sources. I believe, however, if EIA continues the approach that they have followed in the past, the cosmetics related to commercial sector electricity use for the next several years of the AEO will improve. Beginning with the 2008 AEO, EIA may benchmark the model to the 2003 CBECS total consumption. The 2003 CBECS reported electricity use of 3.559 QBtu as compared to the AER (supply-survey estimate) of 4.085 QBtu. The overall magnitude of the difference, 0.526 QBtu, is lower than that implied in the 2007 AEO of some 0.68 QBtu for total "non-building" electricity use.

As we have discussed, the difference of 0.526 QBtu can be presumed to be non-building use and statistical discrepancy. Based on PNNL's analysis of commercial intensities, we can explicitly point to non-building electricity use as being at least $0.330 \mathrm{QBtu}$, or more than $60 \%$ of the AER-CBECS difference for 2003. The other roughly 0.2 QBtu consists of other non-building use (although we cannot point to any major unidentified types of equipment) as well as statistical discrepancy. We would recommend that EIA produce a line item somewhere in the AEO tables that separately identifies this electricity (as well as natural gas) consumption from the electricity estimated to be used within buildings.

\footnotetext{
${ }^{47}$ In the input file containing the forecast market penetration rates ("koffpen.txt"), there is no discussion
} of how the penetration rates were developed. 



\title{
Appendix B \\ FY 2009 BTP Activity Level Benefits Analysis Results
}

\author{
Memorandum, to Jerry Dion, BTP, from Dave Anderson, PNNL \\ December 20, 2007
}





\section{Appendix B}

\section{FY 2009 BTP Activity Level Benefits Analysis Results}

\section{MEMORANDUM}

Date: $\quad$ December 20, 2007

To: Jerry Dion, BTP

From: $\quad$ Dave Anderson, PNNL (509/375-6781, dma@pnl.gov)

Subject: $\quad$ FY 2009 BTP Activity-Level Benefits Analysis Results (PNNL-58057)

\section{Background}

As you know, BTP tasked PNNL in FY 2006 to return to developing activity-level benefits estimates for projects and programs planned to be funded within the Building Technologies Program (BTP) in the FY 2009 Budget. This had been done historically for buildings-sector programs since the inception of the Government Performance and Results Act of 1993 (GPRA), through FY 2005. PNNL last provided official "GPRA" activity-level benefits estimates for FY 2005 in December of 2003. Since that time, EERE-PBA mandated that only benefits estimates developed at the Program level, using integrated modeling approaches, would be made public, and that the scope of analysis should be altered accordingly. ${ }^{1}$ As a result, over the last 4 years, PNNL has provided EERE-PBA with activity characterizations that have informed a corporate analysis of BTP's benefits. ${ }^{2}$ The resulting benefits estimates are what appear in the budget text as benefit measures satisfying GPRA.

In light of EERE-PBA's desire to provide uniform and consistent measures of benefit at the Program level, the need for activity-level benefits estimates such as primary energy savings or carbon-equivalent avoidance has not diminished. BTP stakeholders often have occasion to request specific benefit measures for specific activities. Using the FY 2009 Office of Management and Budget (OMB) Budget of 9/21/2007, PNNL identified the significant "line item" activities to be funded, and then characterized those activities for modeling the expected benefits based on the activities specified in the current BTP Multi-Year Program Plan (MYPP). We produced draft results and presented those to BTP on 11/19/2007, and attached here as PNNL-SA-58057 [deleted]. This memo provides an executive summary of those results. If desired, PNNL will produce a final documentation report for BTP, once the FY 2009 Presidential Budget Request is released.

\footnotetext{
${ }^{1}$ For example, PBA published FY 2008 benefits estimates at the aggregate BTP level only, and only for the period beginning at 2030 and going forward. In the official PBA GPRA documentation, see Figure $3.10 \mathrm{http}: / / \mathrm{www} 1$. eere.energy.gov/ba/pba/pdfs/41347 chap3 .pdf. Note that the acronym GPRA is no longer used and has been replaced by the Portfolio Decision Support, or PDS, function within PBA. 2 Those characterizations are documented on EERE/PBA's Portfolio Decision Support (PDS, formerly GPRA) website, for FY 2008 Budget benefits, in Appendix G available at http://www1.eere.energy.gov/ba/pba/2008 benefits.html.
} 


\section{$\underline{\text { Approach }}$}

PNNL used an interactive approach to developing activity-level benefits estimates. This process includes:

- Reviewing the draft budget request to determine line items planned to be funded for FY 2009

- Consulting the latest publicly available Multi-Year Program Plan (FY07-12) to determine specific actions planned within funded line-items to be carried out with the FY 2009 resources

- Conferring with Technology Development Managers in BTP to identify any changes or clarifications to the information provided in the MYPP, including key expectations and observations about market entry of new technologies, definition of market segments, DOE's role in terms of acceleration of eventual private sector activities, and key performance characteristics.

- Modeling of expected benefits using BEAMS, NEMS-PNNL, and side spreadsheets.

The Buildings Energy Analysis and Modeling System or BEAMS is a PNNL-developed model used to estimate energy metrics for whole-building and envelope research efforts. The following activities were estimated using BEAMS:

- Residential R\&D: Building America

- Commercial R\&D

- Analysis Tools and Design

- Window Technologies

- Thermal Technologies

- Space Conditioning R\&D: Integrated Heat Pump

- Energy Star CFLs

- Home Performance with Energy Star

- Energy Smart Schools and Hospitals

- Builder's Challenge

- Building Application Centers

- Commercial Lighting Initiative

PNNL also maintains a version of the NEMS commercial and residential sector models termed NEMS-PNNL. NEMS-PNNL is used for analyzing technologies and programs addressing appliances or other activities that affect clearly defined market segments or technologies. The following activities were estimated using NEMS-PNNL:

- Lighting R\&D: SSL

- Energy Star Appliances 
The buildings sector covers a diverse set of end uses and technologies, all of which cannot be addressed in energy-savings space by any one model. As such, PNNL uses spreadsheet models for activities that do not fit nicely into established modeling frameworks, or for which established spreadsheet models have been provided by the program. Such activities include:

- Residential and Commercial Research \& Development (zero energy home/zero energy building portion)

- Residential Building Energy Codes

- Commercial Building Energy Codes

- Equipment Standards

Key elements of modeling the expected energy impacts of BTP activities include market segmentation and market penetration. PNNL identifies the specific segment of the market likely to be affected by the introduction of products that would result from BTP research, such as windows, construction materials, lighting, HVAC equipment, appliances, etc. PNNL then applies s-shaped market penetration functions determined from technical reports about technology opportunities, and from expert judgment, to estimate the uptake into the market of products resulting from BTP research.

\section{$\underline{\text { Results }}$}

PNNL models activity-level benefits in an unintegrated fashion. That means that each activity is modeled in isolation from the rest of the activities in the portfolio of research, integration, deployment, and regulatory activities planned by BTP. It also means that activities that may pursue overlapping end uses are not discounted to reflect any overlaps. This approach is valid for making relative comparisons among activities or for considering likely impacts of any one particular activity - which many stakeholder information requests are seeking. Direct summation of activity-level benefits presents a misleading picture of the total benefit, and is not advisable. The "lost opportunities" analyses performed earlier in FY 2007 shed light on what the actual activity integration effect might be. For the Commercial Sector Lost Opportunities report, the activity integration effect was calculated to be about $27 \%$ of the unintegrated total from summing individual activities. This number will be further refined when we complete the integration of both the commercial and the residential sector activities.

PNNL estimated impacts for several energy and environmental measures. In this summary memo, we present primary energy savings and carbon avoidance only, as these tend to be the measures of greatest interest. Table B.1 presents draft primary energy savings by individual BTP activity planned for FY 2009. Remember that these are savings occurring in the year listed, and do not account for previously funded activities undertaken by DOE. Only activities requesting funding for FY 2009 are considered. 
Table B.1. National Primary Energy Savings Attributable to FY 2009 BTP Activities (Source TBtu)

\begin{tabular}{|c|c|c|c|c|c|}
\hline BTP Activity & 2012 & 2015 & 2020 & 2025 & 2030 \\
\hline Residential R\&D: New & 81.3 & 178.8 & 309.5 & 377.9 & 400.1 \\
\hline Residential R\&D: Existing & 0.8 & 1.9 & 3.4 & 4.1 & 4.1 \\
\hline Residential R\&D: ZEB & 3.1 & 8.7 & 26.3 & 51.1 & 75.7 \\
\hline Commercial Integration & 29.4 & 134.0 & 280.8 & 328.2 & 345.5 \\
\hline Lighting R\&D: SSL - Residential & 0.0 & 1.4 & 59.5 & 146.2 & 190.3 \\
\hline Lighting R\&D: SSL - Commercial & 4.0 & 55.4 & 206.1 & 347.7 & 435.1 \\
\hline Space Conditioning R\&D: Integrated Heat Pump & 0.1 & 0.7 & 24.9 & 98.0 & 199.2 \\
\hline Window Technologies: Electrochromic Windows & 12.6 & 41.3 & 130.4 & 249.0 & 340.4 \\
\hline Window Technologies: Superwindows & 5.6 & 25.9 & 163.0 & 397.9 & 569.2 \\
\hline Window Technologies: Low-E Market Acceptance & 6.0 & 18.4 & 52.8 & 84.6 & 97.6 \\
\hline Thermal Technologies: Next Generation Attic Systems & 0.0 & 0.5 & 4.6 & 16.2 & 31.6 \\
\hline Thermal Technologies: Advanced Wall Systems & 1.1 & 4.0 & 16.5 & 35.5 & 50.1 \\
\hline $\begin{array}{l}\text { Thermal Technologies: Next Generation Envelope } \\
\text { Materials }\end{array}$ & 0.0 & 0.1 & 2.7 & 12.9 & 30.7 \\
\hline Analysis Tools and Design & 3.5 & 12.9 & 40.2 & 66.8 & 79.5 \\
\hline Energy Star: Refrigerators & 6.9 & 8.9 & 11.8 & 13.9 & 14.9 \\
\hline Energy Star: Room Air Conditioners & 2.6 & 3.0 & 3.2 & 3.4 & 3.6 \\
\hline Energy Star: Windows & 6.0 & 18.4 & 52.8 & 84.6 & 97.6 \\
\hline Energy Star: CFLs & 210.6 & 298.1 & 358.4 & 413.9 & 457.9 \\
\hline Home Performance with Energy Star & 12.0 & 46.5 & 84.2 & 84.4 & 84.2 \\
\hline Energy Star: Clothes Washers & 4.4 & 5.2 & 8.5 & 15.8 & 26.2 \\
\hline Energy Star: Solid State Lighting & -1.5 & -15.2 & 25.6 & 171.9 & 249.9 \\
\hline TVMI: Commercial Lighting Initiative & 13.3 & 33.7 & 55.7 & 67.5 & 78.4 \\
\hline TVMI: Energy Smart Schools and Hospitals & 11.0 & 16.1 & 18.2 & 18.8 & 18.6 \\
\hline TVMI: Building Application Centers & 0.2 & 0.6 & 1.4 & 1.9 & 2.1 \\
\hline TVMI: Builder's Challenge & 10.6 & 22.3 & 38.2 & 44.7 & 46.1 \\
\hline Building Energy Codes & 34.3 & 78.8 & 162.6 & 252.8 & 344.1 \\
\hline Appliance and Equipment Standards* & 146.4 & 202.9 & 287.5 & 354.1 & 375.7 \\
\hline Unintegrated Totals & 604.2 & 1203.2 & 2428.7 & 3743.9 & 4648.2 \\
\hline
\end{tabular}

Table B.2 presents the estimated avoided carbon emissions derived from the primary energy savings in the previous table. 
Table B.2. National Avoided Carbon Dioxide Emissions Attributable to FY 2009 BTP Activities Million Metric Tons of Carbon Emitted (MMTCE)

\begin{tabular}{lccccc}
\hline BTP Activity & 2012 & 2015 & 2020 & 2025 & 2030 \\
\hline Residential R\&D: New & 1.5 & 3.1 & 5.2 & 6.4 & 6.8 \\
Residential R\&D: Existing & 0.0 & 0.0 & 0.1 & 0.1 & 0.1 \\
Residential R\&D: ZEB & 0.1 & 0.2 & 0.5 & 0.9 & 1.4 \\
Commercial Integration & 0.6 & 2.5 & 5.1 & 6.0 & 6.4 \\
Lighting R\&D: SSL - Residential & 0.0 & 0.0 & 1.2 & 2.8 & 3.7 \\
Lighting R\&D: SSL - Commercial & 0.1 & 1.1 & 4.0 & 6.8 & 8.5 \\
Space Cond R\&D: Integrated Heat Pump & 0.0 & 0.0 & 0.3 & 1.3 & 2.6 \\
Window Technologies: Electrochromic Windows & 0.2 & 0.7 & 2.3 & 4.4 & 6.0 \\
Window Technologies: Superwindows & 0.1 & 0.4 & 2.5 & 6.2 & 9.0 \\
Window Technologies: Low-E Market Acceptance & 0.1 & 0.3 & 0.9 & 1.4 & 1.6 \\
Thermal Technologies: Next Generation Attic Systems & 0.0 & 0.0 & 0.1 & 0.3 & 0.5 \\
Thermal Technologies: Advanced Wall Systems & 0.0 & 0.1 & 0.2 & 0.5 & 0.7 \\
Thermal Technologies: Next Generation Envelope Materials & 0.0 & 0.0 & 0.0 & 0.2 & 0.4 \\
Analysis Tools and Design & 0.1 & 0.2 & 0.7 & 1.2 & 1.5 \\
Energy Star: Refrigerators & 0.1 & 0.2 & 0.2 & 0.3 & 0.3 \\
Energy Star: Room Air Conditioners & 0.1 & 0.1 & 0.1 & 0.1 & 0.1 \\
Energy Star: Windows & 0.1 & 0.3 & 0.9 & 1.4 & 1.6 \\
Energy Star: CFLs & 5.2 & 7.3 & 8.4 & 9.5 & 10.3 \\
Home Performance with Energy Star & 0.2 & 0.7 & 1.3 & 1.3 & 1.3 \\
Energy Star: Clothes Washers & 0.1 & 0.1 & 0.1 & 0.3 & 0.4 \\
Energy Star: Solid State Lighting & 0.0 & -0.3 & 0.5 & 3.3 & 4.9 \\
TVMI: Commercial Lighting Initiative & 0.3 & 0.7 & 1.2 & 1.5 & 1.7 \\
TVMI: Energy Smart Schools and Hospitals & 0.2 & 0.3 & 0.3 & 0.3 & 0.3 \\
TVMI: Building Application Centers & 0.0 & 0.0 & 0.0 & 0.0 & 0.0 \\
TVMI: Builder's Challenge & 0.2 & 0.4 & 0.6 & 0.8 & 0.8 \\
Building Energy Codes & 0.7 & 1.5 & 3.0 & 4.7 & 6.3 \\
Appliance and Equipment Standards* & 2.9 & 4.0 & 5.5 & 6.7 & 7.1 \\
Unintegrated Totals & 12.8 & 23.9 & 45.3 & 68.5 & 84.1 \\
Not & 0.3 & 0.3 \\
\hline
\end{tabular}

Note: These estimates apply to the base budget request - no over-target activities have been included. Also, the activity integration effect would tend to discount the grand totals by about $27 \%$, but this effect is subject to further study.

* The Standards activity includes rulemaking activities for 1-200 HP electric motors and for equipment efficiency standards.

The next set of tables provides comparative results between the FY08 and FY09 benefits analyses. Table B.3 provides the in-year 2025 primary energy savings comparison and Table B.4 provides the inyear 2025 avoided carbon dioxide emissions. 
Table B.3. Year-over-Year Comparison of 2025 In-Year Primary Energy Savings Attributable to the FY08 and FY09 Budget Requests (Source TBtu)

\begin{tabular}{|c|c|c|c|c|}
\hline BTP Activity & FY08 & FY09 & $\begin{array}{c}\text { Yr-over- } \\
\text { Yr } \\
\end{array}$ & Pct. Chg. \\
\hline Research \& Development (Building America) & 423.9 & 433.1 & 9.2 & $2.2 \%$ \\
\hline Commercial Research \& Development & 220.5 & 328.2 & 107.7 & $48.8 \%$ \\
\hline Lighting R\&D & 493.9 & 493.9 & 0.0 & $0.0 \%$ \\
\hline Space Cond R\&D: Integrated Heat Pump & 104.3 & 98.0 & -6.3 & $-6.0 \%$ \\
\hline Space Cond R\&D: Competitive R\&D ${ }^{1}$ & 108.6 & - & -108.6 & $-100.0 \%$ \\
\hline Window Technologies: Electrochromic Windows & 335.8 & 249.0 & -86.8 & $-25.8 \%$ \\
\hline Window Technologies: Superwindows & 368.7 & 397.9 & 29.2 & $7.9 \%$ \\
\hline Window Technologies: Low-E Market Acceptance & 113.8 & 84.7 & -29.2 & $-25.6 \%$ \\
\hline Thermal Technologies: Next Generation Attic Systems & 8.4 & 16.2 & 7.8 & $92.9 \%$ \\
\hline Thermal Technologies: Advanced Wall Systems & 38.1 & 35.5 & -2.6 & $-6.8 \%$ \\
\hline Thermal Technologies: Next Generation Envelope Materials & 13.6 & 12.9 & -0.7 & $-5.1 \%$ \\
\hline Analysis Tools and Design & 51.6 & 66.8 & 15.2 & $29.5 \%$ \\
\hline Rebuild America $^{2}$ & 53.8 & - & -53.8 & $-100.0 \%$ \\
\hline Energy Star: Refrigerators & 13.9 & 13.9 & 0.0 & $0.0 \%$ \\
\hline Energy Star: Room Air Conditioners & 3.4 & 3.4 & 0.0 & $0.0 \%$ \\
\hline Energy Star: Windows & 113.8 & 84.7 & -29.2 & $-25.6 \%$ \\
\hline Energy Star: CFLs & 388.0 & 413.9 & 25.9 & $6.7 \%$ \\
\hline Home Performance with Energy Star & 2.8 & 84.4 & 81.6 & $2914.3 \%$ \\
\hline Energy Star: Clothes Washers & 15.8 & 15.8 & 0.0 & $0.0 \%$ \\
\hline Energy Star: Solid State Lighting & 164.1 & 171.9 & 7.8 & $4.8 \%$ \\
\hline TVMI: Commercial Lighting Initiative & - & 67.5 & 67.5 & $100.0 \%$ \\
\hline TVMI: Energy Smart Schools and Hospitals & - & 18.8 & 18.8 & $100.0 \%$ \\
\hline TVMI: Building Application Centers & - & 1.9 & 1.9 & $100.0 \%$ \\
\hline TVMI: Builder's Challenge & - & 44.7 & 44.7 & $100.0 \%$ \\
\hline Building Energy Codes & 123.3 & 252.8 & 129.5 & $105.0 \%$ \\
\hline Appliance and Equipment Standards* & 344.7 & 354.1 & 9.4 & $2.7 \%$ \\
\hline Unintegrated Totals & 3504.8 & 3743.9 & 239.1 & $6.8 \%$ \\
\hline \multicolumn{5}{|c|}{$\begin{array}{ll}1 & \text { The Competitive R\&D activity under Space Conditioning R\&D was not included in the FY09 Budget Request. } \\
2 & \text { Rebuild America has been transformed into several parts of the TVMI activities in FY09. }\end{array}$} \\
\hline
\end{tabular}


Table B.4. Year-over-Year Comparison of 2025 In-Year Avoided Carbon Dioxide Emissions Attributable to the FY08 and FY09 Budget Requests (MMTCE)

\begin{tabular}{|c|c|c|c|c|}
\hline BTP Activity & FY08 & FY09 & $\begin{array}{c}\text { Yr-over- } \\
\text { Yr } \\
\end{array}$ & Pct. Chg. \\
\hline Research \& Development (Building America) & 8.63 & 7.39 & -1.24 & $-14.4 \%$ \\
\hline Commercial Research \& Development & 4.08 & 6.01 & 1.93 & $47.3 \%$ \\
\hline Lighting R\&D & 9.61 & 9.61 & 0.00 & $0.0 \%$ \\
\hline Space Cond R\&D: Integrated Heat Pump & 1.32 & 1.25 & -0.07 & $-5.3 \%$ \\
\hline Space Cond R\&D: Competitive $R \& D^{1}$ & 1.96 & - & -1.96 & $-100.0 \%$ \\
\hline Window Technologies: Electrochromic Windows & 5.78 & 4.35 & -1.43 & $-24.7 \%$ \\
\hline Window Technologies: Superwindows & 5.73 & 6.24 & 0.51 & $8.9 \%$ \\
\hline Window Technologies: Low-E Market Acceptance & 1.80 & 1.38 & -0.42 & $-23.3 \%$ \\
\hline Thermal Technologies: Next Generation Attic Systems & 0.12 & 0.25 & 0.13 & $108.3 \%$ \\
\hline Thermal Technologies: Advanced Wall Systems & 0.53 & 0.50 & -0.03 & $-5.7 \%$ \\
\hline Thermal Technologies: Next Generation Envelope Materials & 0.19 & 0.18 & -0.01 & $-5.3 \%$ \\
\hline Analysis Tools and Design & 0.97 & 1.24 & 0.27 & $27.8 \%$ \\
\hline Rebuild America $^{2}$ & 0.96 & - & -0.96 & $-100.0 \%$ \\
\hline Energy Star: Refrigerators & 0.27 & 0.27 & 0.00 & $0.0 \%$ \\
\hline Energy Star: Room Air Conditioners & 0.07 & 0.07 & 0.00 & $0.0 \%$ \\
\hline Energy Star: Windows & 1.80 & 1.38 & -0.42 & $-23.3 \%$ \\
\hline Energy Star: CFLs & 8.92 & 9.45 & 0.53 & $5.9 \%$ \\
\hline Home Performance with Energy Star & 0.04 & 1.32 & 1.28 & $3200.0 \%$ \\
\hline Energy Star: Clothes Washers & 0.26 & 0.26 & 0.00 & $0.0 \%$ \\
\hline Energy Star: Solid State Lighting & 3.19 & 3.34 & 0.15 & $4.6 \%$ \\
\hline TVMI: Commercial Lighting Initiative & - & 1.48 & 1.48 & $100.0 \%$ \\
\hline TVMI: Energy Smart Schools and Hospitals & - & 0.34 & 0.34 & $100.0 \%$ \\
\hline TVMI: Building Application Centers & - & 0.04 & 0.04 & $100.0 \%$ \\
\hline TVMI: Builder's Challenge & - & 0.76 & 0.76 & $100.0 \%$ \\
\hline Building Energy Codes & 2.19 & 4.67 & 2.48 & $113.2 \%$ \\
\hline Appliance and Equipment Standards* & 6.51 & 6.69 & 0.18 & $2.8 \%$ \\
\hline Unintegrated Totals & 64.93 & 68.5 & 3.54 & $5.4 \%$ \\
\hline
\end{tabular}

1 The Competitive R\&D activity under Space Conditioning R\&D was not included in the FY09 Budget Request.

2 Rebuild America has been transformed into several parts of the TVMI activities in FY09.

* The Standards activity includes rulemaking activities for 1-200 HP electric motors and for equipment efficiency standards.

Notable changes in the analysis between the two years include the following:

- Adding back the codes deployment portion of the Building Energy Codes activity that had been zeroed out in the FY08 Budget Request.

- Removing the Competitive R\&D portion of Space Conditioning R\&D. 
- Characterizing several new activities under the TVMI line item, and replacing activities previously characterized under Rebuild America.

- Correcting the Commercial R\&D market acceleration and penetration function to more closely follow the equivalent approach used for the residential sector - though still lagging residential by design.

- Adjusting the characterization of the Home Performance with Energy Star activity from that of a pilot program to full program implementation, and correcting a place-value error in the market penetration function.

- Energy Star Windows/Low-E Market Acceptance decline for several reasons including reduced penetration rate (there is less market available — e.g., in the North for new residential more than $82 \%$ are already low-e), revised heating and cooling loads, revised climate regions (we went from 5 to 15 and are better able to match the Energy Star regions).

- In previous years the solar heat gain coefficient (SHGC) for electrochromic windows was modeled as 0.6 for heating and 0.1 for cooling (essentially the limit of the technology); this year it was model as 0.461 for heating and 0.183 for cooling as suggested by $\mathrm{NREL}^{3}$.

- Next Generation Attic Systems (Thermal Technologies) savings improved substantially due to an increase in savings associated with reduced duct losses based on new research.

The remaining differences result from minor corrections in the expected technology performance, market timing, maximum market penetration, or corrections to baseline market information to which the activity performance is being compared, such as year-over-year differences in baseline square footage.

\section{Conclusion}

These results assume program success based on receiving funding as prescribed in the MYPP. The bottom-line total of up to 4.8 Quads in 2030 may well represent the upper bound of what could be achieved, based on FY 2009 planned activities. PNNL has argued previously that the "integrated modeling" effort managed in EERE-PBA develops a program-wide total energy benefit number reflects arbitrary discounting of presumed end-use overlaps, and is likely to under-represent BTP's expected outcomes $^{4}$. The results of the Commercial Lost Opportunities analysis suggest that if we crudely apply the $27 \%$ integration effect, found to apply to the commercial sector, to the entire buildings sector results, the 4.8 QBtu unintegrated total would be more accurately reported to be 3.5 QBtu. We expect to complete the integration of the lost opportunities analysis to include the residential sector by the end of January. At that time we will have a solid quantitative estimate of the integration effect across the buildings sector.

${ }^{3}$ Brent Griffith, Nicholas Long, Paul Torcellini,_Ron Judkoff, Drury Crawley, and John Ryan. April 2007. Commercial Sector Assessment: Part 3 Technical Potential for Achieving Net-Zero-Energy Buildings. Draft Final Report.

${ }^{4}$ Draft FY09 results from PBA are not available as of this memo, but have historically shown significantly lower energy benefits, due in part to the inability of the NEMS and MARKAL models to incorporate as much of the BTP portfolio as the PNNL activity-level approach has incorporated. This limitation recently has been addressed somewhat, but no estimates for comparison of FY09 are available currently. 
PNNL expects to continue to interact with BTP and the managers of specific activities to continually refine and update how the activities are characterized for the models and to acquire more refinement to the market parameters of the models including expected introduction dates, target market segments, and the slope of market penetration functions. 



\section{Appendix C}

\section{Benefits of Solar-Zero Energy Buildings Vision}

Side analysis conducted during the formulation of the Solar Vision initiative 



\section{Appendix C}

\section{Benefits of Solar-Zero Energy Buildings Vision}

Benefits of Solar-Zero Energy Buildings Vison

This spreadsheet uses SAI installed PV target as its starting point. It assumes that the SAI targets will be met through ZEH and Low Energy commercial buildings. The user specifies the split in installations between the residentail and commerical sectors and then the spreadsheet

estimates the energy savings, relative to EIAs projected energy intesities (in AEO 06). This spreadsheet also includes estimated energy savings due to spillover of energy efficiency technologies into non-PV buildings.

\begin{tabular}{lrrr} 
& \multicolumn{3}{c}{ - LOW ESTIMATE -.- } \\
& 2005 & 2015 & 2030 \\
SAI Target (GW) & 0 & 5 & 70 \\
Res share & 0.5 & 0.5 & 0 \\
Comm share & 0.5 & 0.5 & 0.5 \\
Res GW & 0 & 2.5 & 35 \\
Comm GW & 0 & 2.5 & 35 \\
Av Res System Size (kW) & 4 & 4 & \\
Av Comm System Size (kW) & 100 & 100 & 100 \\
Avg Res PV Energy Reduction (million BTU/hh) & 74.95 & 74.95 & 74.95 \\
Avg Comm PV Energy Reduction (thousand BTU/sq ft) & 110.22 & 110.22 & 110.22 \\
Homes with PV (million) & 0.00 & 0.63 & 8.75 \\
Businesses with PV (million) & $\mathbf{0 . 0 0}$ & $\mathbf{0 . 0 3}$ & $\mathbf{0 . 3 5}$
\end{tabular}

Av Household Source Energy Cons (millon BTU/hn)

Av Comm Energy Cons thousand BTU/sq ft)

$185 \quad 178$

178
239

Total Number of households (million)

Share of households with PV

$\begin{array}{rr}130 & 150 \\ 0.5 \% & 5.8 \%\end{array}$

PV Comm roof space intensity (sq ft/kW)

Comm roof space with PV (bill sq ft)

Comm floorspace / roofspace factor

Comm floorspace with PV on roof (bill sq ft)

Total Comm floorspace (bill sq ft)

Share of comm buildings with PV

$\begin{array}{rr}100 & 100 \\ 0.25 & 3.5 \\ 1.7 & 1.7 \\ 0.425 & 5.95 \\ 89 & 112 \\ 0.5 \% & 5.3 \%\end{array}$

PV-Zero Energy Buildings Energy Savings - Assuming 100\% Energy Displacement Household Energy Savings (Quads)

Household EE Energy Savings (Quads)

Commercial Energy Savings (Quads)

Commercial PV Energy Savings (Quads)

Commercial EE Energy Savings (Quads)

0.07

PV-ZEB Energy Savings (Quads)

Additional Energy Savings from Spillover per below

Total Energy Savings w/spillover (Quads)

$\begin{array}{ll}0.22 & 2.98 \\ 0.22 & 0.99\end{array}$

\begin{tabular}{rrr}
- & \multicolumn{3}{c}{ HIGH ESTIMATE } \\
2005 & 2015 & 2030 \\
0 & 10 & 100 \\
0.5 & 0.5 & 0.5 \\
0.5 & 0.5 & 0.5 \\
0 & 5 & 50 \\
0 & 5 & 50 \\
4 & 4 & 4 \\
100 & 100 & 100 \\
74.95 & 74.95 & 74.95 \\
110.22 & 110.22 & 110.22 \\
$\mathbf{0 . 0 0}$ & $\mathbf{1 . 2 5}$ & $\mathbf{1 2 . 5 0}$ \\
$\mathbf{0 . 0 0}$ & $\mathbf{0 . 0 5}$ & $\mathbf{0 . 5 0}$
\end{tabular}

Color Coding

Key paramet

Key Output

Added by AKN

75

$190 \quad 185 \quad 178$ From AEO 06

239 From AEO 06

$\begin{array}{rrr}115 & 130 & 150 \text { From AEO } 06\end{array}$

$8.3 \%$

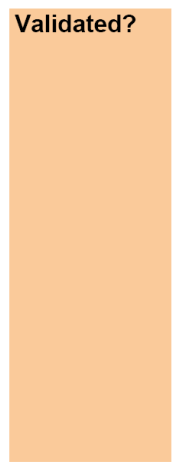

yes

100 Based on Powerlight installs

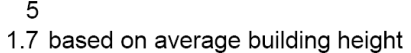

8.5

112 From AEO 06

$7.6 \%$

$0.0 \%$

$1.0 \%$

2.23

0.94

0.00

0.23
0.09

1.29

0.14
0.20

2.03
0.94

1.09
$\mathbf{4 . 2 6}$

$\begin{array}{ll}0.43 & 4.26 \\ 0.44 & 1.60\end{array}$

0.44
0.88

5.86

682074950845

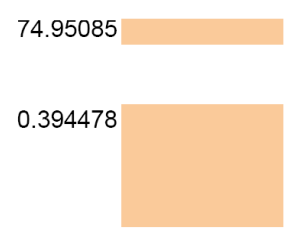




\begin{tabular}{|c|c|c|c|c|}
\hline \multicolumn{5}{|c|}{ Assuming Spillover of "Zero Energy" technologies on the end-use and design side only. NO rooftop PV } \\
\hline & --- LOW ESTIMAT & & --- HIGH ESTIMA & \\
\hline & 2015 & 2030 & 2015 & 2030 \\
\hline \multicolumn{5}{|l|}{ Residential } \\
\hline Savings per HHold, \% over EIA Reference Case & $35 \%$ & $50 \%$ & $35 \%$ & $50 \%$ \\
\hline Savings per HHold (million Btu/HH) & 64.75 & 89 & 64.75 & 89 \\
\hline Percent of Total Stock of Hholds Adopting & $2.0 \%$ & $5.0 \%$ & $4 \%$ & $8 \%$ \\
\hline Total Number of Households Adopting (Million) & 2.6 & 7.5 & 5.2 & 12 \\
\hline $\begin{array}{l}\text { Savings (Quads) } \\
\text { Commercial }\end{array}$ & 0.17 & 0.67 & 0.34 & 1.07 \\
\hline Savings per SF, \% over Reference Case & $25 \%$ & $40 \%$ & $25 \%$ & $40 \%$ \\
\hline Savings per SF (kBtu) & 59.8 & 95.6 & 59.8 & 95.6 \\
\hline Percent of Total Stock of SF adopting & $1.0 \%$ & $3.0 \%$ & $2.0 \%$ & $5.0 \%$ \\
\hline Total Amt of Square Footage Adopting (billion) & 0.89 & 3.36 & 1.78 & 5.60 \\
\hline Savings (Quads) & 0.05 & 0.32 & 0.11 & 0.54 \\
\hline Total Savings, All Buildings (quads) & 0.22 & 0.99 & 0.44 & 1.60 \\
\hline
\end{tabular}

AEO Reference Case Projections

Total Resid Energy (Quads)

Total Comm Energy (Quads)

Resid \& Comm Energy (Quads)

$22 \quad 24$

Change over 2005 (Quads)

$\begin{array}{ll}24 & 27 \\ 21 & 27 \\ 45 & 54\end{array}$

27
27
54
14

22
18

$24 \quad 27$ From AEO 06

27 From AEO 06

yes

Energy savings share w/Spillover

Resid

Comm

Total Buildings Energy Savings (Share)

$5 \quad 14$

$45 \quad 54$

yes

Energy savings as share of INCREMENTAL Quads

$\begin{array}{rrrr}1.2 \% & 8.2 \% & 2.4 \% & 12.2 \% \\ 0.7 \% & 6.5 \% & 1.5 \% & 9.5 \% \\ \mathbf{1 . 0} \% & \mathbf{7 . 3} \% & \mathbf{1 . 9 \%} & \mathbf{1 0 . 9 \%} \\ \mathbf{8 . 8} \% & \mathbf{2 8 . 3} \% & \mathbf{1 7 . 5 \%} & \mathbf{4 1 . 9 \%}\end{array}$

EIAs projected capacity additions (ALL Capaicity additions, not just Natural Gas)

\begin{tabular}{|c|c|c|c|c|c|c|}
\hline Cummulative addtions (GW) & 23 & 80 & 312 & 23 & 80 & 312 From AEO 06 \\
\hline PV Capacity PV installed & 0 & 5 & 70 & 0 & 10 & $100 \mathrm{Comb}$ of PV and EE gives $\sim 1 \mathrm{ELCC}$ \\
\hline Capacity displaced (= PV installed * scale factor) & 0 & 6.25 & 87.5 & 0 & 12.5 & 1.25 Add displaced due to EE \\
\hline Share Capacity Additions Displaced & $0 \%$ & $8 \%$ & $28 \%$ & $0 \%$ & $16 \%$ & $40 \%$ \\
\hline \multicolumn{7}{|l|}{ Carbon Emissions } \\
\hline Resid (million metric tons $\mathrm{CO} 2$ ) & 1246 & 1369 & 1576 & 1246 & 1369 & 1576 From AEO 06 \\
\hline Comm (million metric tons $\mathrm{CO}$ ) & 1055 & 1233 & 1620 & 1055 & 1233 & 1620 From AEO 06 \\
\hline Total (milloin metric tons $\mathrm{CO} 2$ ) & 2301 & 2602 & 3196 & 2301 & 2602 & 3196 \\
\hline CO2 Emissions Avoided (mil metric tons $\mathrm{CO} 2$ ) & 0 & 25 & 235 & 0 & 51 & 347 Assume proportional to energy savings \\
\hline Carbon emissions avoided in MMTCE & \multicolumn{2}{|c|}{ 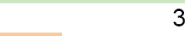 } & 48 & & 7 & \multirow{2}{*}{68} \\
\hline MMTCE per Source Quad 2010 to 2020 & 16 & buildin & tabook. & $/ / \mathrm{docs} / \mathrm{t}$ & pdf & \\
\hline
\end{tabular}

MMTCE per Source Quad 2010 to 2020

$16 \mathrm{http}: / /$ buildingsdatabook.eere.energy.gov/docs/6.4.1.pdf 
Appendix D

Benefits of the Vision 



\section{Appendix D}

\section{Benefits of the Vision}

\section{Benefits of the Vision}

Displacing a significant amount of conventional electricity production with new energy technologies is a major challenge-immediate, decisive action is needed. The Solar-Zero Energy Buildings Vision (the Vision) will accelerate the rate at which solar energy technologies combined with energy efficiency technologies will displace conventional energy sources. As shown in Table D.1, by 2030 the Vision is projected to displace roughly 4-6 Quads of energy consumption in the U.S. buildings sector, which represents $7 \%-11 \%$ of total projected U.S. residential and commercial building energy consumption. ${ }^{1}$ Achieving cost competitiveness and accelerated use of solar and energy efficient technologies will represent a turning point that will shape how Americans use energy in buildings, and will also have a significant impact on the evolution of the U.S. electricity generation system. Under the Vision, the combination of solar and energy efficient technologies is projected to displace the need for $88-125 \mathrm{GW}$ of new generating capacity though 2030, which accounts for roughly $30-40 \%$ of projected electric capacity additions between 2005 and 2030. The Vision will also have significant impacts on greenhouse gas emissions, displacing 235-350 million metric tons of CO2 per year in 2030.

Table D.1. Benefits of the Vision

\begin{tabular}{lcc}
\hline Benefit & $\mathbf{2 0 1 5}$ & $\mathbf{2 0 3 0}$ \\
\hline Energy Savings (Quads) & $0.4-0.9$ & $4-6$ \\
Share of Building Energy Consumption Displaced (\%) & $1-2$ & $7-11$ \\
Share of Growth in Building Energy Displaced (\%) & $9-18$ & $28-42$ \\
Electric Generation Capacity Displaced (GW) & $6-12$ & $88-125$ \\
Share of Electricity Capacity Additions Displaced (\%) & $8-16$ & $28-40$ \\
$\mathrm{CO}_{2}$ Emissions Avoided (million metric ton $\mathrm{CO}_{2} /$ year) & $25-51$ & $235-347$ \\
Share of Building $\mathrm{CO}_{2}$ Displaced (\%) & $1-2$ & $7-11$ \\
\hline
\end{tabular}

The starting point for estimating these benefits was the Solar America Initiative (SAI)'s installed capacity targets for PV: 5-10 GW of PV installed by 2015 and 70-100 GW of PV installed by 2030. These targets were based on a combination of model-generated results (DOE 2006; Margolis and Wood 2004), the U.S. PV Industry Roadmap (SEIA 2004), and a review of near-term industry growth projections published by industry consultants (Navigant 2006; Rogol et al. 2006).

The SAI targets were expanded in the following ways to estimate total energy savings:

- It was assumed that the SAI targets will be met through a combination of zero energy homes and low energy commercial buildings. Energy savings were estimated using a 50-50 split between residential and commercial buildings and projected energy intensities for residential and commercial buildings drawn from EIA’s Annual Energy Outlook (2006) reference case projection.

\footnotetext{
${ }^{1}$ The EIA's Annual Energy Outlook (2006) reference case projects that the residential and commercial
} buildings sector will consume 54 Quads of energy in 2030. 
- Additional energy savings were estimated assuming "spillover" of zero/low energy technologies on the end-use and design side for buildings without solar. This spillover was projected to cover $2-4 \%$ of the residential/commercial building stock by 2015 and 5-8\% of the residential/commercial building stock by 2030 For these buildings energy consumption was assumed to be reduced $35 \%$ in 2015 and $50 \%$ in 2030 .

- Total energy savings includes energy savings in both the zero/low energy buildings with solar and spillover buildings without solar (energy savings is split roughly $75 \%-25 \%$ respectively).

- The share of building energy displaced was calculated relative to EIA's Annual Energy Outlook (2006) reference case projected residential and commercial sector energy consumption.

The electricity generation capacity displaced due to zero/low energy buildings with solar was then estimated assuming a one-to-one offset of capacity for installed PV. This level of capacity displacement can be achieved through a combination of solar technology, efficiency and smart building energy management practices. Similarly, spillover buildings without solar were assumed to displace capacity through a combination of energy efficiency and energy management practices. The total electricity generation capacity displaced was then calculated as the sum of capacity displaced by zero/low energy buildings with solar, and capacity displaced by spillover buildings without solar. The share of capacity additions displaced was calculated relative to EIA's Annual Energy Outlook (2006) reference case projected electricity generation capacity additions.

Finally, avoided $\mathrm{CO}_{2}$ emissions were estimated assuming that $\mathrm{CO} 2$ emissions offsets would be proportional to energy savings, i.e., a $10 \%$ reduction in energy use would result in a $10 \%$ reduction in $\mathrm{CO} 2$ emissions. Here baseline $\mathrm{CO}_{2}$ emissions from the residential and commercial sector were based on EIA's Annual Energy Outlook (2006) reference case projections, and reductions were calculated relative to this baseline.

\section{References}

DOE (Department of Energy) (March 2006). Projected Benefits of Federal Energy Efficiency and Renewable Energy Programs FY 2007 Budget Request. Washington, DC: Office of Energy Efficiency and Renewable Energy, U.S. Department of Energy.

EIA (Energy Information Administration) (2006). Annual Energy Outlook 2006. DOE/EIA-0383(2006). Washington, DC: Energy Information Administration.

Margolis, R.M.; Wood, F. (2004). "The Role for Solar in the Long-Term Outlook of Electric Power Generation in the U.S." Presented at the IAEE North American Conference, Washington, DC, July 2004.

Navigant Consulting (April 2006). Analysis of Worldwide Markets for Photovoltaic Products and FiveYear Application Forecast. NPS-Global 1. Palo Alto, CA: Navigant Consulting.

Rogol, M; Choi, P; Conkling, J.; Fotopoulos, A.; Peltzman, K.; Roberts, S. (July 2006). Solar Annual 2006: The Gun Has Gone Off. Germany: Photon Consulting.

SEIA (Solar Energy Industries Association) (September 2004). Our Solar Power Future: The U.S. Photovoltaics Industry Roadmap Through 2030 and Beyond. Washington, DC: Solar Energy Industries Association. 



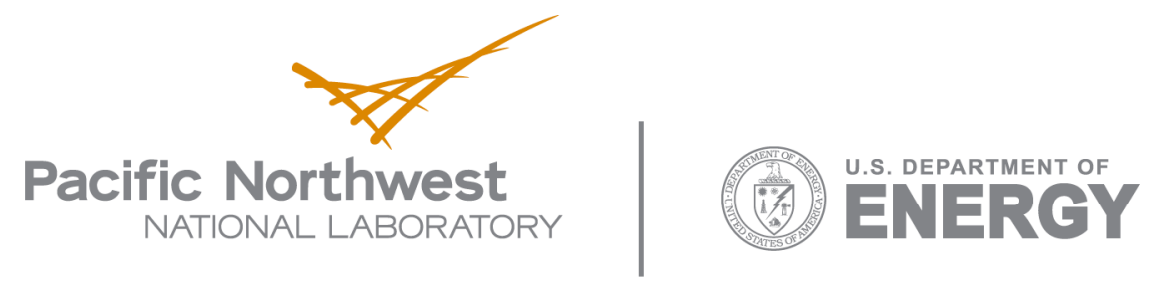

902 Battelle Boulevard

P.O. Box 999

Richland, WA 99352

1-888-375-PNNL (7665)

www.pnl.gov 